Effects of hydrolyzed oat bran proteins on free radicals, toxic metals and lipid oxidation

\title{
By
}

\section{Adenike Shittu}

A thesis submitted to the Faculty of Graduate and Postdoctoral Affairs in partial fulfillment of the requirements for the degree of

\author{
Master of Science \\ In \\ Chemistry \\ (Concentration in Food Science and Nutrition)
}

\author{
Carleton University \\ Ottawa, Ontario, Canada
}

(C) 2017, Adenike Shittu 
The undersigned hereby recommends to the

Department of Chemistry

acceptance of the thesis

\title{
Effects of hydrolyzed oat bran proteins on free radicals, toxic metals and lipid oxidation
}

\author{
Submitted by: \\ ADENIKE SHITTU \\ In partial fulfillment for the degree of \\ Master of Science, Chemistry
}

\author{
Dr. Apollinaire Tsopmo \\ Thesis Supervisor
}

Dr. Zhongwen Wang

Thesis Co-supervisor 


\section{Abstract}

Transition metals play an important role in wide variety of biological processes in living system. Exposure to toxic metals, specifically arsenic (As) and chromium (Cr), has been associated with inflammation, cellular damage, and cardiovascular diseases as a result of As/Cr-mediated oxidative stress. In recent years, food proteins have been of major interest because in addition to being sources of essential amino acids they can also provide bioactive peptides. Several studies have found that these food peptides exhibit antioxidant, anti-inflammatory and anti-hypertensive properties. Oat is the sixth consumed type of cereal and its use in human nutrition has been increasing in recent years because of the discovery of functional and biological activity of some of its constituents. In the present study, medium oat bran was pre-treated with cellulase and viscozyme to degrade the carbohydrase, followed by the hydrolysis of the isolated proteins with proteases; alcalase (AL), papain (PA), flavourzyme (FL), and protamex (PRO). We investigated the characteristics of the oat bran protein isolates (OBPI) and the oat bran protein hydrolysates (OBPH), their ability to reduce the toxicity of arsenic and chromium as well as their radical scavenging properties. OBPI samples include cellulase (CELL) and viscozyme (VISC) pre-treated protein isolates respectively. OBPH samples were named based on the carbohyrase and protease used in hydrolysis; CAL, CPA, CFL, CPRO, VAL, VPA, VFL, VPRO. Results showed that OBPIs possessed higher protein contents $(80 \%)$ and higher molecular weight (MW $>20 \mathrm{kDa}$ ) than the OBPH with an average of $45 \%$ protein content and $\mathrm{MW}<15 \mathrm{kDa}$. OBPIs exhibited higher levels of aromatic amino acid residue $(\mathrm{p}<0.05)$ compared to OBPHs. Meanwhile, aromatic amino acid contents varied among OBPHs due to difference in specificities of proteases. In the peroxyl radical scavenging (ORAC) assay, OBPHs from viscozyme treated brans performed better than those from cellulase. VFL and VAL had the highest ORAC value ranging from $565 \pm 80-640 \pm 57 \mu \mathrm{M} \mathrm{TE} / \mathrm{g}$ respectively compared to $406.3 \pm 43-506.7 \pm 65 \mu \mathrm{M} \mathrm{TE} / \mathrm{g}$ for hydrolysates from cellulase treated bran. VISC and 
CELL isolates had lower ORAC values ranging from $107.9 \pm 13.5-305.8 \pm 28.3 \mu \mathrm{M} \mathrm{TE} / \mathrm{g}$ respectively compared to OBPHs. Hydrolysis increased peroxyl radical scavenging activities (ORAC) but lowered hydroxyl radical $(\mathrm{HO} \bullet)$ potentials while only minor changes were observed in the superoxide anion radical scavenging power. OBPIs and OBPHs had no effect on lipid peroxides in non-stored samples (NS) and $-20{ }^{0} \mathrm{C}$ storage, however storage at $4{ }^{0} \mathrm{C}$, cellulase treated OBPHs had lower concentration of lipid peroxide compared to viscozyme.

Data on the effect of OBPI and OBPH on arsenic showed that at $-20{ }^{0} \mathrm{C}$, treated samples had higher concentration of As (III) compared to NS, but mostly lower concentration compared to $4{ }^{0} \mathrm{C}$. Concentration of As (V) in treated samples is mostly lower compared to NS and $4{ }^{0} \mathrm{C}$. Non-stored samples (NS) treated with CELL and CFL had the highest $(\mathrm{p}<0.05)$ concentrations of As (III) compared to other samples. All OBPI and OBPH samples had similar concentration of As (V) compared to control (untreated sample). It was concluded that the increase in concentrations of As (III) in treated samples might be due to its affinity for binding to proteins or peptides present in OBPI and OBPH. Samples treated with VISC and CPRO had highest concentration of As (III) at $4{ }^{0} \mathrm{C}$ compared to other OBPI and OBPH treated samples. At $-20{ }^{\circ} \mathrm{C}$, there was no significant difference in the effect of OBPIs and OBPHs on As (III) and As (V) compared to control. CAL had the highest concentration of As (V). In chromium reducing assay, samples stored at $-20{ }^{\circ} \mathrm{C}$ generally had lower concentration of $\mathrm{Cr}$ (VI) compared to NS and $4{ }^{0} \mathrm{C}$, while the concentration of $\mathrm{Cr}$ (III) was mostly higher compared to NS and 4 ${ }^{0} \mathrm{C}$. All samples had lower concentration of $\mathrm{Cr}(\mathrm{VI})$ and higher concentration of $\mathrm{Cr}$ (III) compared to control (non-treated). 


\section{Dedication}

To my husband, my parents and my sibling who has always been the best support physically and emotionally. Motivating and encouraging me in every way to achieve my dreams and to be the best I can. I love you all. 


\section{Acknowledgement}

I will like to offer my sincerest gratitude to Almighty God for successfully taking me through this journey. I owe a special thanks to my husband and my family for their constant support and encouragement.

A special thank you to my Supervisor, Dr. Apollinaire Tsopmo, for giving me the opportunity to work with him and also for his academic and moral support. Even at inconvenient times, he is always ready to help. He is my inspiration and role model.

I will like to thank my Co-supervisor, Dr. Zhongwen Wang (Food Research Division, Bureau of Chemical Safety, Food Directorate, Health Canada, Ottawa), for giving me the opportunity to work in her Laboratory, taking time to train, guide and encourage me to be a better scientist. She is a great mentor.

A warm thanks to Chemistry department and Carleton University for all the funds and busaries provided for the research. Thanks to my colleagues from Dr. Tsopmo's group, for being the most awesome sets of people to work with.

I am also grateful to all my friends, Rowida Mohammed, Shana Cameron and well-wishers who helped in all possible ways. 


\section{Table of contents}

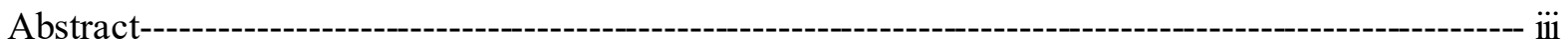

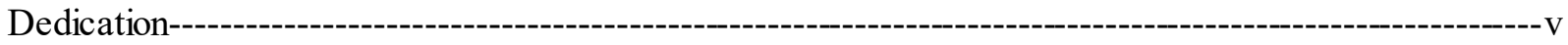

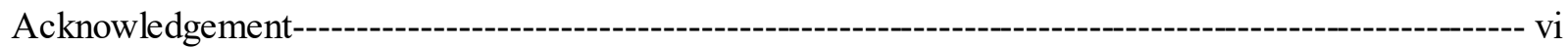

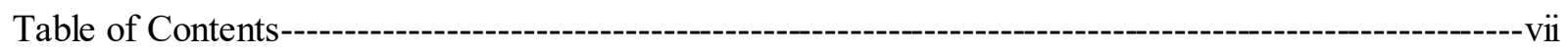

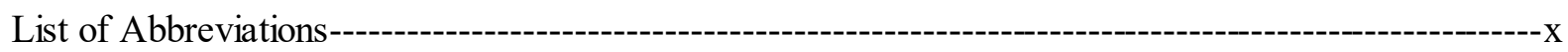

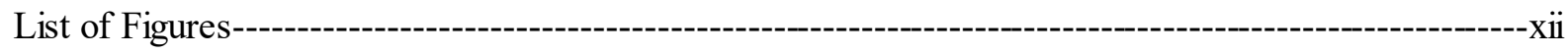

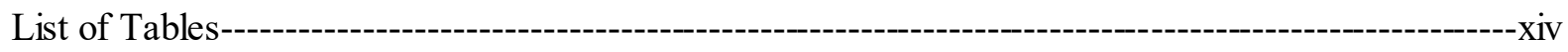

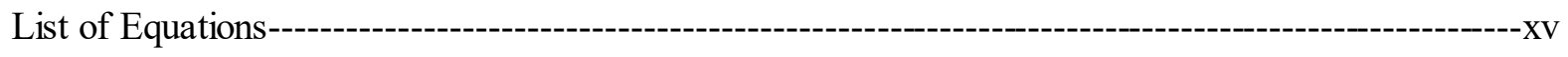

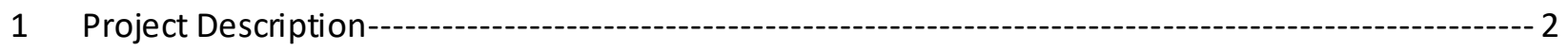

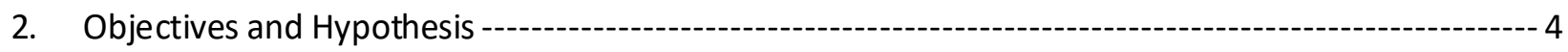

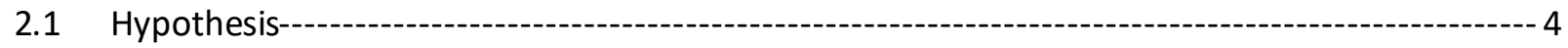

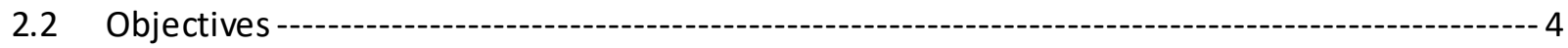

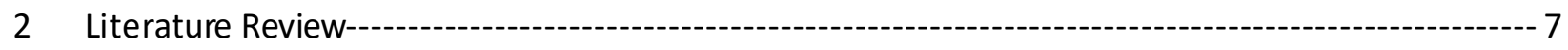

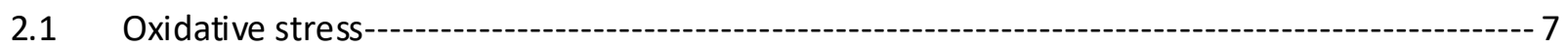

2.1.1 Reactive Oxygen Species (ROS) --

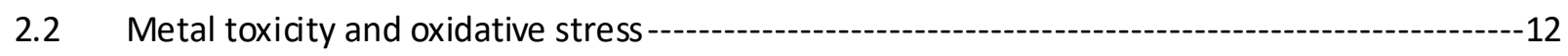

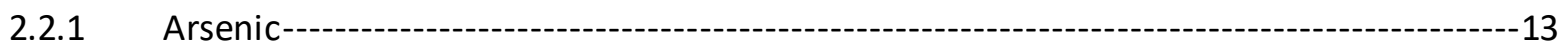

2.2.2 Chromium ---

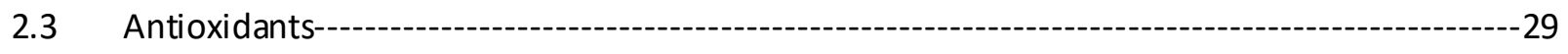

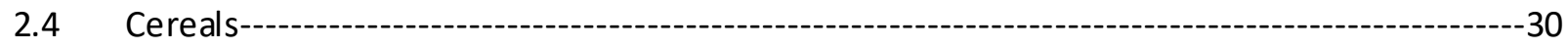

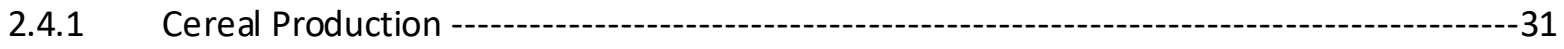


2.5 Oats -- 33

2.5.1 Oat Production and Distribution--

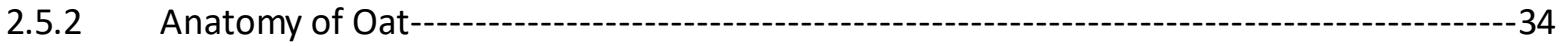

2.5.3 Oat Processing ---

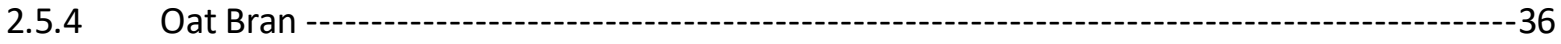

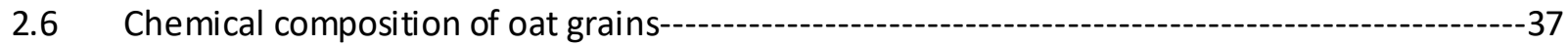

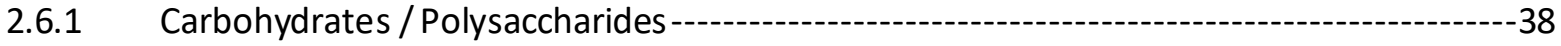

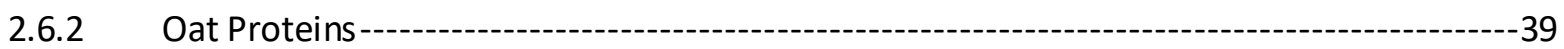

2.7 Bioactivity of hydrolyzed proteins / peptides--

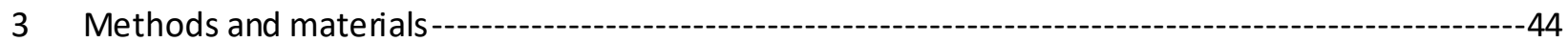

3.1 Materials and reagents---10

3.2 Defatting medium oat bran flour---

3.3 Extraction of proteins---

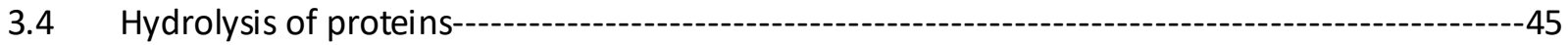

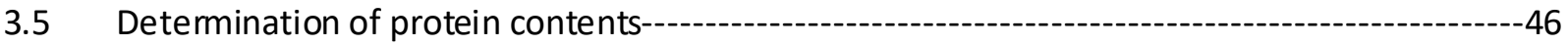

3.6 Sodium Dodecyl Sulfate-Polyacrylamide Gel Electrophoresis (SDS-PAGE) -----------------------47

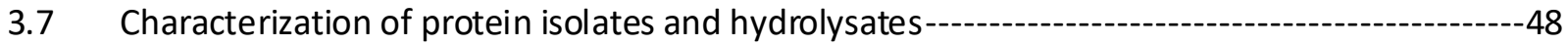

3.7.1 Intrinsic Absorbance of Protein and Hydrolysates-----

3.7.2 Sulfhydryl (-SH) Assay -----

3.8 In vitro antioxidant activities of OBPIs and OBPHs - 
3.8.1 Determination of Oxygen Radical Absorbance Capacity (ORAC)---

3.8.2 Hydroxyl Radical (HO`) scavenging assay--

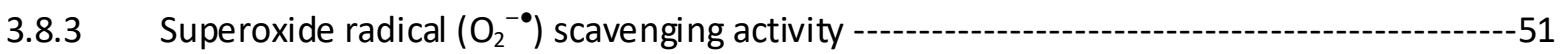

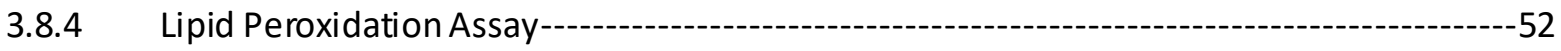

3.9 Processing of meat samples for analyzing arsenic and chromium species ---------------52

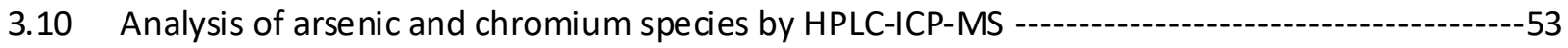

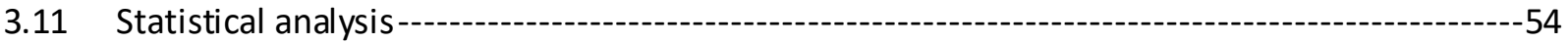

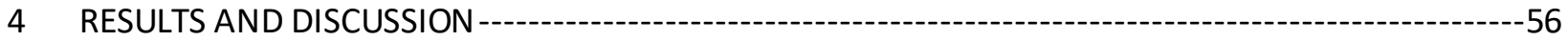

4.1 Protein contents of isolates and hydrolysates ---

4.2 Molecular weight distribution of samples--

4.3 Intrinsic Ultraviolet Absorbance ---

4.4 Quantification of sulfhydryl (-SH) group --

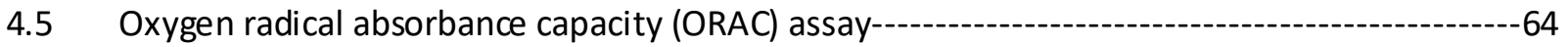

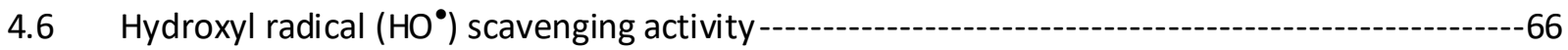

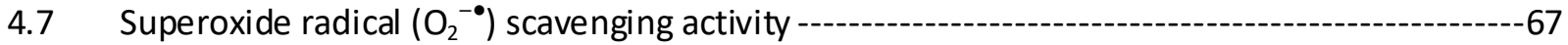

4.8 Inhibition of lipid peroxidation in meat----

4.9 Effect of protein isolates and hydrolysates on arsenic in meat---.--1

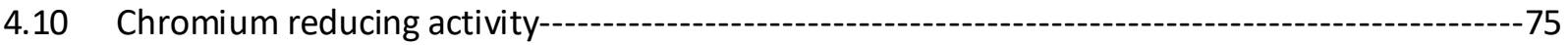

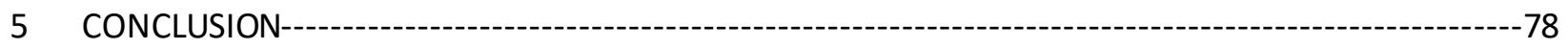

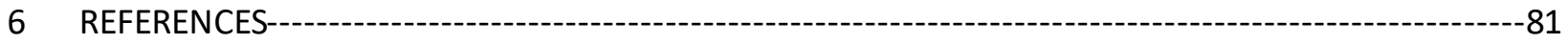




\section{List of Abbreviations}

\begin{tabular}{|c|c|}
\hline${ }^{1} \mathrm{O}_{2}$ & Singlet Oxygen \\
\hline 8-OHDG & 8-Hydroxy-2-Deoxyguanosin \\
\hline 8-OH-G & 8-Hydroxyguanine \\
\hline As (III) & Arsenite, Arsenious Acid, Trivalent Arsenic \\
\hline As $(V)$ & Arsenate,Arsenic Acid, Pentavalent Arsenic \\
\hline $\mathrm{AT}_{1} \mathrm{R}$ & angiotensin II Type I receptor \\
\hline ATP & Adenosine-5-triphosphate \\
\hline $\mathrm{Cr}(\mathrm{IV})$ & Tetravalent chromium \\
\hline $\mathrm{Cr}(\mathrm{V})$ & Pentavalent chromium \\
\hline $\mathrm{Cr}$ (III) & Trivalent chromium \\
\hline $\mathrm{Cr}(\mathrm{VI})$ & Hexavalent chromium \\
\hline DMAIII & Dimethylarsinous Acid \\
\hline DMAV & Dimethylarsinic Acid \\
\hline DNA & Deoxyribonucleic acid \\
\hline EPA & US Environmental protection agency \\
\hline ETC & Electron Transport Chain \\
\hline GPx & Glutathione peroxidase \\
\hline GS $\bullet$ & Glutathione radical \\
\hline GSH & Glutathione \\
\hline GSSG & Glutathione disulfide \\
\hline $\mathrm{H}_{2} \mathrm{O}_{2}$ & Hydrogen Peroxide \\
\hline $\mathrm{HO}^{\bullet}$ & Hydroxyl Radical \\
\hline
\end{tabular}


IARC

$\mathrm{L}^{\bullet}$

LDL

$\mathrm{LOO}^{\bullet}$

MAC

MAPK

MDA

MMAIII

MMAV

$\mathrm{NADPH}$

$\mathrm{O}_{2}$

$\mathrm{O}_{2}^{-\bullet}$

$\mathrm{OBPH}$

OBPI

ORAC

PUFA

RNS

ROO ${ }^{\bullet}$

ROS

SDS-PAGE

SOD

WHO
International Agency for Research on Cancer

Lipid radical

Low Density Lipoprotein

Lipid peroxyl radical

Maximum Acceptable Concentration

mitogen-activated protein kinase

Malondialdehyde

Monomethylarsonous Acid

Monomethylarsonic Acid

Nicotinamide adenine dinucleotide phosphate

Molecular oxygen

Superoxide

Oat Bran Protein Hydrolysate

Oat Bran Protein Isolate

Oxygen radical absorbance capacity

Poly Unsaturated Fatty Acids

Reactive Nitrogen specie

Peroxyl Radical

Reactive Oxygen Species

Sodium Dodecyl Sulfate-Polyacrylamide Gel Electrophoresis

Superoxide dismutase

World Health Organization 


\section{List of Figures}

Figure 1: mechanism of lipid peroxidation

Figure 2: Mechanism involved in arsenic metabolism ........................................................ 17

Figure 3: Binding of arsenite to sulphur containing group in protein ......................................... 19

Figure 4: Summary of mechanisms involved in arsenic-induced oxidative stress leading to cancer........22

Figure 5: Biological mechanism of Chromium (VI) and Cr-induced oxidative stress...........................26

Figure 6 : Phylogeny of Cereal Grains. Adapted from ........................................................... 31

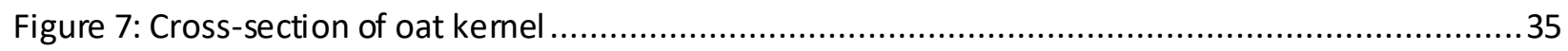

Figure 8: Different oat physical appearance as a result of processing (1) whole groats, (2) steel-cut groats,

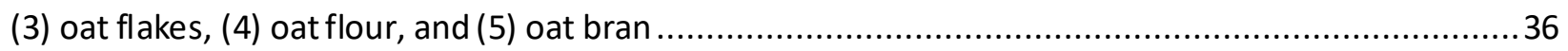

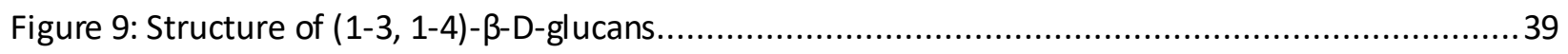

Figure 10: Classifications of oat proteins based on solubility ..................................................... 41

Figure 11 : HPLC/ICP/MS chromatograms of chromium speciation in meat samples spiked with $\mathrm{Cr}(\mathrm{VI})$ and

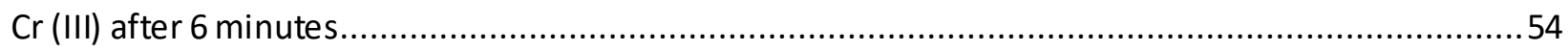

Figure 12 : HPLC/ICP/MS chromatograms of arsenic speciation in meat samples spiked with As (III) and As

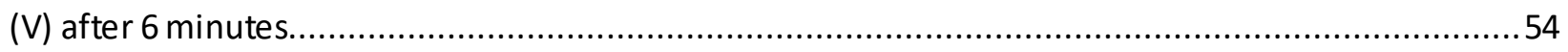

Figure 13: Protein content of oat bran hydrolysates as determined by Lowry assay, using Bovine serum

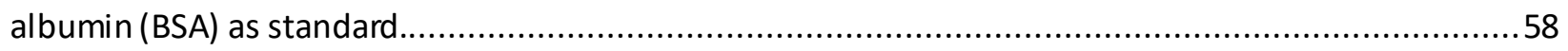

Figure 14: SDS-PAGE of isolates and hydrolysates dissolved in buffer containing $2 \%(\mathrm{v} / \mathrm{v}) 2$ -

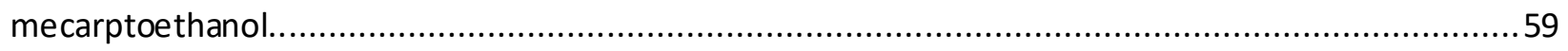

Figure 15: Ultraviolet absorbance of intrinsic protein in hydrolyzed and non-hydrolyzed oat bran protein samples; absorbance reading recorded at wavelength $280 \mathrm{~nm}$ for amino acid residue.......................61

Figure 16: Free sulfhydryl groups in oat bran protein isolates and protein hydrolysates....................63 
Figure 17: Total sulfhydryl groups in oat bran protein isolates and protein hydrolysates. Disulphide bonds were hydrolyzed with 2-mecaptoethanol. 63

Figure 18: Antioxidant activity (ORAC value $\mu \mathrm{M} \mathrm{TE/g} \mathrm{sample)} \mathrm{of} \mathrm{OBPI} \mathrm{and} \mathrm{OBPH} \mathrm{samples...................66}$

Figure 19: Hydroxyl radical scavenging activity of OBPI and OBPH samples. ...............................68

Figure 20: Superoxide radical scavenging activity of OBPI and OBPH samples..............................69

Figure 21: Lipid peroxidation inhibition of OBPI and OBPH samples.......................................... 71

Figure 22: Effect of protein isolates and hydrolysates on arsenic species; trivalent (As (III)) and pentavalent

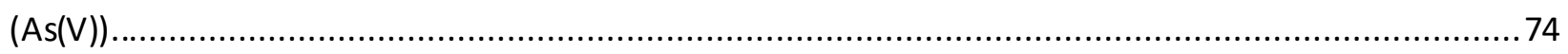

Figure 23: Activity of OBPI and OBPH samples to reduce hexavalent $(\mathrm{Cr}(\mathrm{VI}))$ to trivalent ( $\mathrm{Cr}(\mathrm{III}))$ chromium.. 


\section{List of Tables}

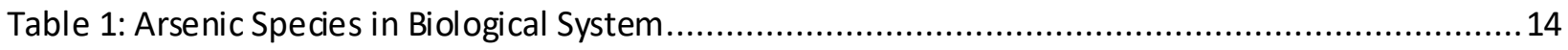

Table 2 Total Arsenic Concentration in Various Food Groups from Canada....................................15

Table 3: World Cereal production; cultivated area 2010 - 2014............................................... 32

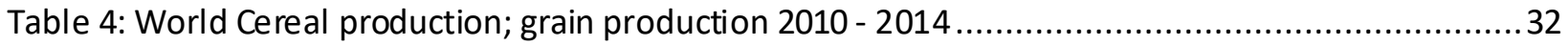

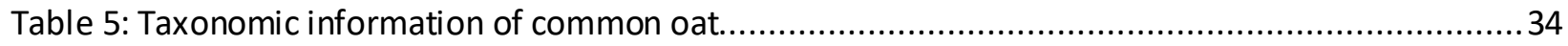

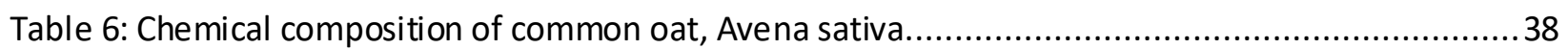

Table 7: Hydrolysis of proteins extracted by Viscozyme and Cellulase ........................................ 46 


\section{List of Equations}

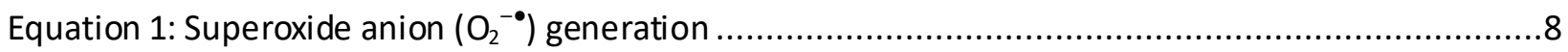

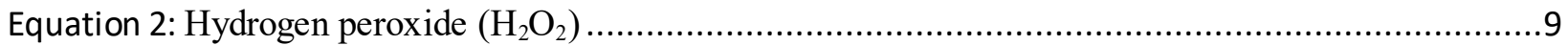

Equation 3: Hydroxyl $\operatorname{radical}\left(\mathrm{HO}^{\bullet}\right)$ through Haber Weiss reaction ............................................. 10

Equation 4: Hydroxyl radical $\left(\mathrm{HO}^{\bullet}\right)$ through Fenton reaction................................................. 10

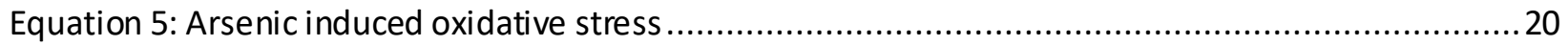

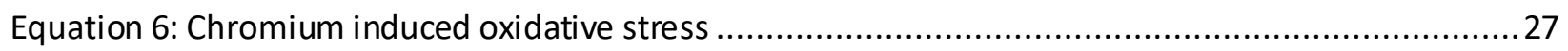

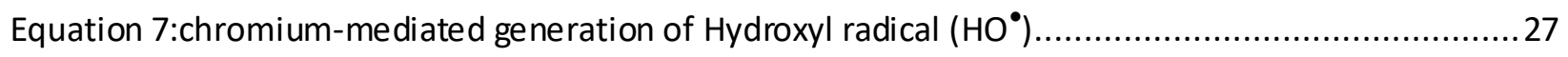

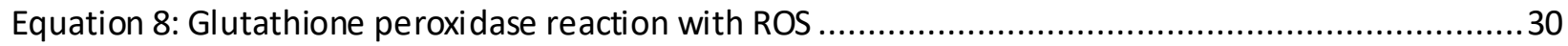

Equation 9: Glutathione peroxidase reaction with hydroperoxides .......................................... 30

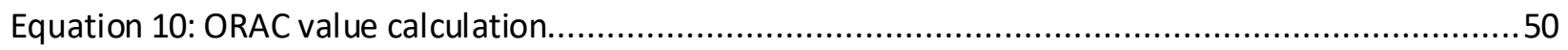

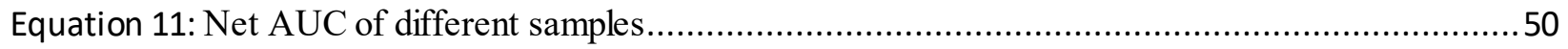

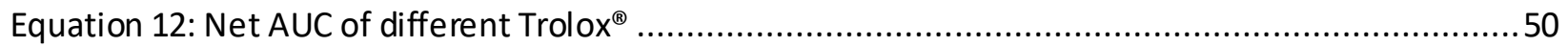

Equation 13: Hydroxyl radical $(\mathrm{HO} \bullet)$ scavenging activity calculation ....................................... 51

Equation 14: Superoxide anion $\left(\mathrm{O}_{2}^{-\bullet}\right)$ scavenging activity calculation......................................... 52

Equation 15: Reaction of disulphide bonds in OBPI and OBPH with 2-mecaptoethanol .....................64 


\section{Chapter 1 Introduction and Rationale}




\section{$1 \quad$ Project Description}

In recent years, foods have been recognized to provide the human body with more than just energy and essential nutrients. Naturally occurring minor components in foods often referred to as phytochemicals possess health-promoting properties in chronic conditions such as cardiovascular diseases and certain cancers (R. H. Liu, 2013). The effects have been attributed to various phenolic molecules, but also to fibers and more recently to peptides released from the hydrolysis of proteins (Butt, Tahir-Nadeem, Khan, Shabir, \& Butt, 2008)

Cereals are an important sources of energy and nutrients and are highly consumed worldwide. Oat is the sixth highest consumed type of cereal and its use in human nutrition has been increasing in recent years because of the discovery of functional and biological activity of some of its constituents (Ryan, Thondre, \& Henry, 2011). Bran is a by-product of cereal processing and is rich in health promoting molecules like dietary fibres, B-complex vitamins, proteins, fat, minerals, and polyphenols (Butt et al., 2008). Recent studies have indicated that protein from bran can be treated with proteases to release peptides with various biological functions such as antioxidant, anti-inflammation, anti-hypertensive, and antimicrobial (Alrahmany, Avis, \& Tsopmo, 2013; Aluko, 2012; Gao, Smith, \& Tsopmo, 2014). Proteins from food samples are generally hydrolyzed through microbial fermentation, enzymatic digestion, and chemical hydrolysis (Korhonen \& Pihlanto, 2003). Sufficient availability of antioxidant molecules is important for the maintenance of the body's redox system and prevention of chronic diseases (Young \& Woodside, 2001). Factors such as light, UV radiation, oxygen, and free metals can cause oxidative stress or accelerate food deterioration, hence the importance of antioxidants for the maintenance of foods and increased shelf life. Carbohydrase such as cellulase, amyloglucosidase and viscozyme are used to enhance the efficiency of protein extraction from cereal brans (Jodayree, Smith, 
$\&$ Tsopmo, 2012). Some of the proteases commonly used for in vitro digestion of food proteins are alcalase, papain, nutrase, flavourzyme and protamex (Ou et al., 2010; Tsopmo, Gao, \& Baakdah, 2014). In addition to their antioxidant properties, hydrolyzed proteins can chelate transition metal ions thereby reducing their toxicity and pro-oxidant effects. Transition metals can initiate radical reactions, some of which can contribute to the oxidation of lipids in foods or biological system and to DNA oxidation (Lou et al., 2013). Natural and synthetic antioxidants are used in lipid-rich food products to reduce lipid oxidation and to prevent other deleterious effects of ROS. Natural antioxidant have high activity, easy absorption, and little or no negative side effects (Sarmadi \& Ismail, 2010). Despite the low cost of synthetic antioxidants, there is increasing concern over the safety of synthetic antioxidants such as butylated-hydroxyanisole, butylated-hydroxytoluene, and tert-butylhydroquinone (Lobo, Patil, Phatak, \& Chandra, 2010); which has prompted food scientists to focus on identifying and developing new natural and cost-effective antioxidants. Hydrolyzed food proteins (or hydrolysates) are considered as potential sources of non-toxic natural antioxidants. Several studies have been done to investigate the antioxidant properties of food protein-derived peptides and hydrolysates from both animal and plant protein sources (Li et al., 2010; Sheih, Fang, Wu, \& Lin, 2010).

Transition metals play important roles in a wide variety of biological processes in living organisms; however their toxicity has been discovered to be enhanced as a result of oxidative stress (Valko, Morris, \& Cronin, 2005). Chromium and arsenic are examples of metals that can cause DNA damage and be carcinogenic. One of the mechanisms of toxicity for transition metals is through the production of reactive oxygen species (ROS). Molecules that can convert toxic forms of these metals to non-toxic ones, and at the same time reduce oxidative stress will therefore be useful for the maintenance of human health. 


\section{Objectives and Hypothesis}

Hydrolyzed proteins possess antioxidant properties because of the presence of certain amino acids that can transfer protons to free radicals. Sulfur-containing amino acids can be preferentially oxidized thereby preventing damage to biological molecules. The reducing power of thiol can attenuate the toxic effect of transition metals as found with the amino acid cysteine and the biologically relevant peptide glutathione. The effect of other thiol containing peptides on toxic metals has not been investigated. It is therefore possible that other molecules such as food-derived peptides can attenuate the metal toxicity. This is possible because many proteins in foods possess thiol-containing amino acids (e.g. cysteine, methionine) and other functional groups that can reduce or chelate transition metals in foods, cell cultures or biological system.

\subsection{Hypothesis}

It was hypothesized that treatment of isolated proteins with proteases of various specificities will release peptides with antioxidant properties. Furthermore, it was hypothesized that the released antioxidant peptides will reduce the toxicity of metals such as chromium and arsenic due to the presence of thiol groups within the peptide sequence.

\subsection{Objectives}

Objectives of this work were to:

1. Hydrolyze oat bran protein isolates with proteases such as alcalase, papain, flavourzyme and protamex followed by their characterization based on size (SDS-PAGE), total protein content and amino acid composition

2. Determine the antioxidant properties of the isolated proteins and their hydrolysate peptides using radical scavenging assays. 
3. Determine the effect of the isolated proteins and their hydrolysate peptides on arsenic and chromium in food. 


\section{Chapter 2 \\ Literature Review}




\section{Literature Review}

\subsection{Oxidative stress}

Free radicals or oxidants are physiologically generated through normal reactions in the body during respiration in aerobic organisms. Oxidative stress, also known as Redox Imbalance is a situation that occurs when there is an imbalance between the production of oxidants in a system and their elimination by antioxidant defences, thereby resulting in disturbed cellular metabolism and regulation, and damaged cellular constituents (Breitenbach \& Eckl, 2015). Oxidative damages to cellular constituents such as DNA, lipids and proteins are as a result of excessive production of Reactive Oxygen Species (ROS) and Nitrogen Species (RNS) in the system with limited antioxidant defences (Turrens, 2003). ROS/RNS physiologically produces free radicals, hence are highly reactive and naturally present in human body. ROS are produced in response to inflammation, aging, radiation, air pollution and exposures to different physicochemical conditions (TPA et al., 2004). RNS are generated from nitric oxide (NO) and peroxides (OONO), produced by the mitochondrial respiratory chain when the cell is oxygen deficie nt (hypoxia) (Srivastava, Singh, Patel, \& Singh, 2017). When ROS/RNS reacts with biomolecules, they can result in the damage of proteins, oxidation of membrane phospholipids, mutations in DNA and modifications in Low Density Lipoproteins (LDL) (Baran, Zeigler, \& Tridandapani, 2004). The free radicals produced has different functions like providing defense against infections, however, the cellular damages caused by excess reactive species or reactive radicals can initiate or contribute to several chronic diseases such as cardiovascular diseases, atheroscleros is, arthritis, Alzheimer, diabetes and cancer (Sarmadi \& Ismail, 2010). 


\subsubsection{Reactive Oxygen Species (ROS)}

Most of oxidants that initiate or contribute to oxidative stress contain oxygen. Some ROS have unpaired electrons (radical) and some do not (non-radical), so they react with biomolecules such as DNA, lipids, carbohydrates and proteins by either donating or accepting an electron from them in order to gain stability (Dalle-Donne et al., 2006). ROS radicals includes superoxide anion $\left(\mathrm{O}_{2}^{-\bullet}\right)$, hydroxyl radical $\left(\mathrm{HO}^{\bullet}\right)$ and peroxyl radical $\left(\mathrm{ROO}^{\bullet}\right)$ while the non-radicals includes hydrogen peroxide $\left(\mathrm{H}_{2} \mathrm{O}_{2}\right)$ and singlet oxygen $\left({ }^{1} \mathrm{O}_{2}\right)$ (Rahman, Hosen, Islam, \& Shekhar, 2012). One of the mechanisms of action of ROS is their reaction with polyunsaturated fatty acids (PUFA) to induce the release of toxic and reactive aldehyde metabolites such as malondialdehyde (MDA), one of the end products of lipid peroxidation (Yeh et al., 2005).

\subsubsection{Superoxide $\left(\mathrm{O}_{2}^{-\bullet}\right)$}

Superoxide $\left(\mathrm{O}_{2}^{-\bullet}\right)$ is one of the ROS produced in the cell with a short half-life of $10^{-6}$ seconds (Burgess \& Shewry, 1986). Oxygen $\left(\mathrm{O}_{2}\right)$ is very important in the oxidative processes that occur in the cell and it is also essential for the survival of the cell. When oxygen is inhaled, it goes through the cell mitochondria where it is reduced by the normal oxidative phosphorylation step in the electron transport chain (ETC) reactions to produce adenosine-5-triphosphate (ATP), a source of energy in the cell (Rahman et al., 2012). During this normal ETC reactions, there is $1-3 \%$ leakage of electrons directed towards oxygen $\left(\mathrm{O}_{2}\right)$, thereby generating superoxide $\left(\mathrm{O}_{2}^{-\bullet}\right)$ which can be further reduced to other reactive oxygen species (Halliwell \& Gutteridge, 2015). Superoxide $\left(\mathrm{O}_{2}^{-\bullet}\right)$ can also be generated in phagocytes by reducing one electron from oxygen $\left(\mathrm{O}_{2}\right)$ by enzyme oxidases such as nicotinamide adenine dinucleotide phosphate (NADPH) oxidase, xanthine oxidase (XO) (Sies, 1993).

$$
\mathbf{O}_{2}+\mathbf{e}^{-} \rightarrow \mathbf{O}_{2}^{-\bullet} \quad \text { Equation } 1
$$


The generation of superoxide anion in the cell has been associated with different diseases such as chronic inflammation and various cancers (K. Shah, R. G. Kumar, S. Verma, 2001; Rahman et al., 2012; Srivastava et al., 2017). When superoxide (free radical) react with lipids, the lipids undergo peroxidation, hence forming lipid peroxides which decompose to form several toxic products such as malondialdehyde (MDA) (Beckman \& Koppenol, 1996). A study investigated the relationship between the levels of superoxide and lipid peroxidation in the blood of breast cancer patients (117 diagnosed women) and they observed that the rate of superoxide production was significantly higher in the blood of the breast cancer patients compared to healthy volunteers (control) (Yeh et al., 2005). This was determined by estimating the amount of malondialdehyde (MDA) produced as a result of the oxidation of PUFA by superoxide anion in the cancer breast patients. Several other studies have examined the possible correlation between ROS, lipid oxidation and cancer.

\subsubsection{Hydrogen peroxide $\left(\mathrm{H}_{2} \mathrm{O}_{2}\right)$}

Hydrogen peroxide $\left(\mathrm{H}_{2} \mathrm{O}_{2}\right)$ is a relatively stable ROS with a long half-life of 60 seconds compared to $\mathrm{O}_{2}{ }^{-\bullet}$. It is derived from dismutation of superoxide radical $\left(\mathrm{O}_{2}^{-\bullet}\right)$ from the electron transport chain (Halliwell \& Gutteridge, 2015) and enzymatically activated by mitochondria superoxide dismutase (SOD) enzyme (Srivastava et al, 2017). $\mathrm{H}_{2} \mathrm{O}_{2}$ is one of the non-radical ROS because it has no unpaired electrons, hence far less reactive compared to superoxide radical.

$$
2 \mathrm{O}_{2}^{-\bullet}+2 \mathrm{H}^{+} \stackrel{\text { SOD }}{\rightarrow} \quad \mathrm{H}_{2} \mathrm{O}_{2}+\mathrm{O}_{2} \quad \text { Equation } 2
$$

As a result of its polarity, $\mathrm{H}_{2} \mathrm{O}_{2}$ mixes readily with water, so it is permeable to the plasma membrane and can easily diffuse within and between the cells (Noori, 2012). Even though there is no oxidation when $\mathrm{H}_{2} \mathrm{O}_{2}$ reacts with DNA, $\mathrm{H}_{2} \mathrm{O}_{2}$ causes damages to the DNA by oxidizing the thiol (-SH) groups of the enzymes involved in catalysis, resulting in inactivation of the enzymes (Aruoma, 1998). Production of 
$\mathrm{H}_{2} \mathrm{O}_{2}$ results in the inhibition of mitochondrial respiration, inhibition of $\mathrm{Na}^{+} / \mathrm{K}^{+}$pump function and phosphorylation of kinases which leads to cellular damage such as inactivation of peroxiredoxins, chloroplast glucose biophosphate and the glycolytic enzyme (G3PDH) (Halliwell \& Gutteridge, 2015; Noori, 2012; Rahman et al., 2012). Poly unsaturated fatty acids (PUFA) and $\mathrm{H}_{2} \mathrm{O}_{2}$ acts as intermediates in lipid peroxides formation in the cell membrane (Mylonas \& Kouretas, 1999). $\mathrm{H}_{2} \mathrm{O}_{2}$ plays an important role in the formation of highly reactive oxygen species such as hydroxyl radical $\left(\mathrm{HO}^{\bullet}\right)$ which is produced by the interaction of $\mathrm{H}_{2} \mathrm{O}_{2}$ with transition metals such as Iron and copper (Noori, 2012).

\subsubsection{Hydroxyl radical $\left(\mathrm{HO}^{\circ}\right)$}

Hydroxyl radical $\left(\mathrm{HO}^{\bullet}\right)$ is one of the most reactive forms of ROS produced in the cell with a short halflife of less than $10^{-9}$ seconds in aqueous solution (TPA et al., 2004). It attacks most cellular components and damage them. Haber Weiss postulated that superoxide anion $\left(\mathrm{O}_{2}{ }^{-\bullet}\right)$ reacts with hydrogen peroxide $\left(\mathrm{H}_{2} \mathrm{O}_{2}\right)$ to produce hydroxyl radical $\left(\mathrm{HO}^{\bullet}\right)$ and the reaction is facilitated by metal catalysts (Kotyzova, Hodkova, Bludovska, \& Eybl, 2013).

Haber Weiss reaction:

$$
\mathrm{O}_{2}^{-\bullet}+\mathrm{H}_{2} \mathrm{O}_{2} \underset{\text { Catalyst }}{\stackrel{\text { Metal }}{\rightarrow}} \mathrm{O}_{2}+\bullet \mathbf{O H}+\mathrm{OH} \text { Equation } 3
$$

Fenton reaction:

$$
\mathrm{H}_{2} \mathrm{O}_{2}+\mathrm{Fe}^{2+} \rightarrow \mathrm{Fe}^{3+}+{ }^{\bullet} \mathrm{OH}+\mathrm{OH}^{-}
$$

Equation 4

Through Fenton's reaction, hydrogen peroxide $\left(\mathrm{H}_{2} \mathrm{O}_{2}\right)$ reacts with ions of transition metals such as iron or copper to form hydroxyl radical $\left(\mathrm{HO}^{\bullet}\right)$ (Leonard, Harris, \& Shi, 2004), hence the relationship between transition metals toxicity and oxidative stress is studied.

\subsubsection{Peroxyl radical}

Lipid autoxidation occurs both in food and biological system and causes oxidative degradation of lipids, hence developing unpleasant flavour and taste, loss of nutrient and formation of toxic 
compounds (Martinez-monteagudo, 2016). Several molecular damages occur as a result of oxidation by reactive oxygen species. The oxidation of polyunsaturated fatty acids in food and cell membranes results in the formation of lipid peroxyl radicals $\left(\mathrm{LOO}^{\bullet}\right)$ generated in three major steps: initiation, propagation and termination (Figure1). Briefly, the reaction is initiated through the attack of unsaturated lipid by hydroxyl radicals generated from Haber Weiss or Fenton reaction (Section 2.1.1.3), stealing a hydrogen atom and leaving the lipid with an unpaired electron, hence forming a lipid radical $\left(\mathrm{L}^{\bullet}\right)$. In the propagation step, the unstable lipid radical reacts readily with molecular oxygen to generate a lipid peroxyl radical (LOO ${ }^{\bullet}$ ) which is also unstable. Lipid peroxyl radical reacts with another unsaturated fatty acid to generate a different lipid radical and lipid peroxide. The lipid radical that was generated starts the cycle again by reacting with hydroxyl radical or other reactive oxygen species. The termination step occurs when the concentration of free lipid radicals in the cell membrane is high enough that they react with other lipid radical to generate a non-radical species (Baky \& El-Baroty, 2013).

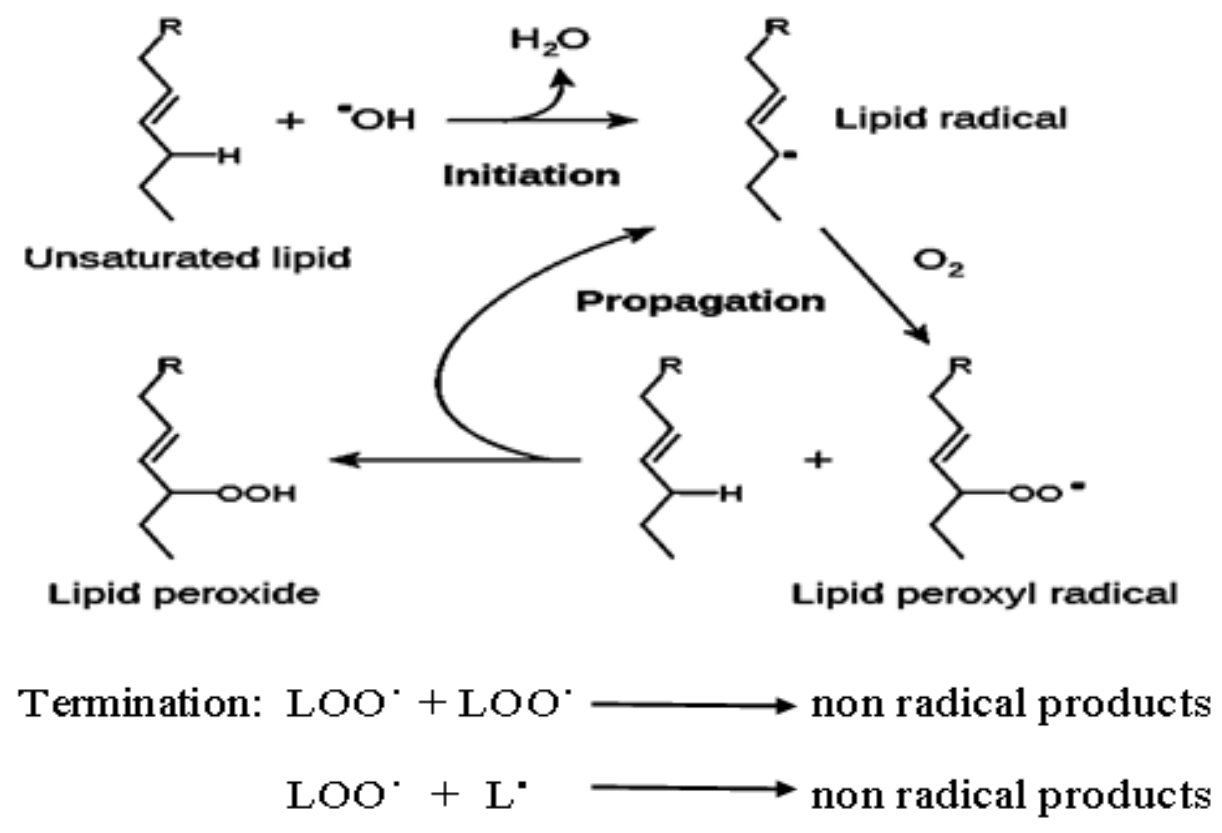

Figure 1: me chanism of lipid peroxidation 


\subsection{Metal toxicity and oxidative stress}

Metal plays important roles in a wide variety of biological processes in living systems. Environmental and occupational exposure to metals have been associated with the development of inflammations, cellular damage and several cardiovascular diseases, especially lung and skin cancer (Leonard et al, 2004). Carcinogenesis caused by metals has been previously investigated by different researchers, but the mechanism of action of metals especially at molecular level are still inconclusive (Baakdah \& Tsopmo, 2016; Z. Fang et al., 2014; K. Jomova et al., 2011; Navas-Acien et al., 2005). These carcinogenic metals include arsenic (As), chromium $(\mathrm{Cr})$, cadmium $(\mathrm{Cd})$, cobalt (Co), beryllium $(\mathrm{Be})$, nickel $(\mathrm{Ni})$, lead $(\mathrm{Pb})$, and iron $(\mathrm{Fe})$. Some of the potential sources of exposure to these metals includes but not limited to dietary exposure, groundwater contamination, leather tanning, mining, and metal production (Henkler, Brinkmann, \& Luch, 2010). The levels of exposure to these metals are regulated, for example according to the guideline for Canadian drinking water by Health Canada, maximum acceptable concentration to cadmium, arsenic and lead in drinking water are $5 \mu \mathrm{g} / \mathrm{L}, 10 \mu \mathrm{g} / \mathrm{L}$ and $8 \mu \mathrm{g} / \mathrm{L}$ respectively (Health Canada, 2006).

After exposures, metal-ion transporters help in maintaining the required levels of metal ions in various compartments of the cell. The breakdown of metal-ion homeostasis can lead to the metal binding to protein sites that they are not supposed to or the metal-ion replace other metals from their natural binding sites and if the situation remains uncontrolled, there will be formation of deleterious free radicals, modifications of DNA bases, enhanced lipid peroxidation and altered calcium and thiol homeostasis (Klaudia Jomova \& Valko, 2011; Tsopmo et al., 2014). Reactive oxygen species (ROS), products of metal-catalyzed reactions are classified as redox-active metals. The roles of these redoxactive metals in initiating or catalyzing the reactions involved in the production of ROS as well as their toxicity and carcinogenicity has been a growing area of research for many years, but there is still not enough convincing evidence showing that oxidative stress is the primary cause of their toxicity 
(Halliwell \& Gutteridge, 2015). For example, the main functions of iron (Fe) in the cell is to transport oxygen to the tissues (Valko, Rhodes, Moncol, Izakovic, \& Mazur, 2006a). Deficiency of iron can lead to impaired formation of iron-containing proteins and inhibition of cell growth, eventually leading to cell death (Klaudia Jomova \& Valko, 2011). However the exaggeration or abnormal uptake of iron results in the formation of iron-mediated ROS which leads to lipid and DNA damage (Valko et al., 2006a).

Mechanisms of reactions involved in metal-mediated generation of free radicals include the Fenton-type and Haber-Weiss-type reactions as explained in Section 2.1.1., while some metal ions such as iron, arsenic and chromium can react directly with cellular molecules to generate free radicals (Beyersmann \& Hartwig, 2008). Among all of these metals, arsenic and chromium are particularly of interest not only because they are naturally and widely distributed in the environment due to their many industrial applications but also because they can directly react with biomolecules and they have better evidence suggesting that their toxicity is enhanced carcinogenicity via an oxidative stress mechanism (Faita, Cori, Bianchi, \& Andreassi, 2013; Halliwell \& Gutteridge, 2015; Henkler et al., 2010; Klaudia Jomova \& Valko, 2011).

\subsubsection{Arsenic}

Arsenic (As) is a toxic metalloid that is widely distributed in the earth's crust and is also known to be a human carcinogen (Aposhian \& Aposhian, 2006). The toxicity of arsenic depends mostly on its oxidoreduction state (trivalent or pentavalent) and its methylation state (monomethyl, dimethyl or trimethyl), which occurs during the process of metabolism in mammals (S. Cohen, Ohnishi, Arnold, \& Le, 2007). Table 1 shows some of the commonly known species of arsenic that are present in the environment naturally and in biological systems. 
Arsenic can exist in four valence or oxidation states: $-3,0,+3$, and +5 , in which it is able to form both inorganic and organic compounds in the environment and within the human body (K.

Jomova et al., 2011).

Table 1: Arsenic Species in Biological System

\begin{tabular}{|l|c|c|}
\hline Name & Abbreviation & Chemical formula \\
\hline Arsenite, arsenious acid, trivalent As & As (III) & $\mathrm{As}(\mathrm{OH})_{3}$ \\
\hline Arsenate, arsenic acid, pentavalent As & As (V) & $\mathrm{AsO}(\mathrm{OH})_{3}$ \\
\hline Monomethylarsonic acid & $\mathrm{MMA}^{\mathrm{V}}$ & $\mathrm{CH}_{3} \mathrm{AsO}(\mathrm{OH})_{2}$ \\
\hline Monomethylarsonous acid & $\mathrm{MMA}^{\mathrm{III}}$ & $\mathrm{CH}_{3} \mathrm{As}(\mathrm{OH})_{2}$ \\
\hline Dimethylarsinic acid & $\mathrm{DMA}^{\mathrm{V}}$ & $\left(\mathrm{CH}_{3}\right)_{2} \mathrm{AsO}(\mathrm{OH})$ \\
\hline Dimethylarsinous acid & $\mathrm{DMA}^{\mathrm{III}}$ & $\left(\mathrm{CH}_{3}\right)_{2} \mathrm{AsOH}$ \\
\hline Trimethylarsine oxide & $\mathrm{TMAO}_{3}$ & $\left(\mathrm{CH}_{3}\right)_{3} \mathrm{AsO}$ \\
\hline Trimethylarsine & $\mathrm{TMA}^{\mathrm{III}}$ & $\left(\mathrm{CH}_{3}\right)_{3} \mathrm{As}$ \\
\hline Arsenobetaine & $\mathrm{AsB}$ & $\left(\mathrm{CH}_{3}\right)_{3} \mathrm{As}^{+} \mathrm{CH}_{2} \mathrm{COO}-$ \\
\hline Arsenocholine & $\mathrm{AsC}$ & $\left(\mathrm{CH}_{3}\right)_{3} \mathrm{As}^{+} \mathrm{CH}_{2} \mathrm{CH} \mathrm{OH}_{2}$ \\
\hline Tetramethylarsonium ion & $\mathrm{Me}_{4} \mathrm{As}$ & $\left(\mathrm{CH}_{3}\right)_{4} \mathrm{As}^{+}$ \\
\hline Dimethylarsinoyl ethanol & $\mathrm{DMAE}^{+}$ & $\left(\mathrm{CH}_{3}\right)_{2} \mathrm{AsOCH}_{2} \mathrm{CH} \mathrm{OH}_{2}$ \\
\hline
\end{tabular}

Arsenic compounds does not have colour or smell, therefore, their presence is not immediately obvious in food, water or air, thus presenting a serious hazard on human health given the nature of arsenic toxicity (Leonard et al., 2004). The health risk posed by arsenic depends on the type and quantity of arsenic species accumulated from the sources of exposures.

\subsubsection{Sources and exposure to arsenic}

The main sources of exposure to arsenic are through occupational exposure (pesticides production or application, electronics, wood preservation, pigments, smelting and mining), dietary exposure (fish, rice, seafood, seaweed and cereals), and environmental exposure (ground water or drinking water) which is 
associated with cancers of urinary bladder, lung, skin, liver and kidney (Hughes, Beck, Chen, Lewis, \& Thomas, 2011a).

The largest source of arsenic is usually through food, specifically seafood and it is mostly in the organic form called arsenobetaine which is non-toxic compared to other forms of arsenic. Table 2 shows the result of the study done in Canada to assess the concentration of arsenic in various food groups consumed by adults and infants (Dabeka, McKenzie, \& Lacroix, 1993).

Table 2 Total Arsenic Concentration in Various Food Groups from Canada (Dabeka et al., 1993)

\begin{tabular}{|c|c|c|c|}
\hline \multirow[t]{2}{*}{ Food category } & \multirow[t]{2}{*}{ Sample size } & Mean & Range \\
\hline & & \multicolumn{2}{|c|}{$\mu \mathrm{g} \mathrm{As} / \mathrm{kg}$ wet weight } \\
\hline Milk and dairy products & 89 & 3.8 & $<0.4-26$ \\
\hline Meat and poultry & 124 & 24.3 & $<1.3-536$ \\
\hline Fish and shellfish & 40 & 1662 & $77.0-4830$ \\
\hline Soups & 28 & 4.2 & $<0.2-11$ \\
\hline Bakery goods and cereals & 177 & 24.5 & $<0.1-365$ \\
\hline Vegetables & 262 & 7 & $<0.1-84$ \\
\hline Fruits and fruit juices & 176 & 4.5 & $<0.1-37$ \\
\hline Fats and oils & 21 & 19 & $<1.0-57$ \\
\hline Sugar and candies & 49 & 10.9 & $1.4-105$ \\
\hline Beverages $^{\mathrm{a}}$ & 45 & 3 & $0.4-9$ \\
\hline Miscellaneous $^{b}$ & 33 & 12.5 & $<0.8-41$ \\
\hline \multicolumn{4}{|c|}{$\begin{array}{l}\text { a includes: coffee, tea, soft drinks, wine and canned and bottles beer. } \\
\text { b includes: bran muffins, muffins with and without raisins, gelatine deserts, } \\
\text { raisins, baked beans, wieners, and raw and canned beets. }\end{array}$} \\
\hline
\end{tabular}

Millions of people drink water with arsenic levels that far exceed the $10 \mu \mathrm{g} / \mathrm{L}(0.01 \mathrm{mg}$ As per Liter) guideline established by the World Health Organization (WHO) and U.S. Environmental Protection Agency (EPA) (Hughes, Beck, Chen, Lewis, \& Thomas, 2011b). In Canada, the maximum acceptable concentration (MAC) set by Health Canada for arsenic in drinking water is 10 $\mu \mathrm{g} / \mathrm{L}$ based on municipal- and residential-scale treatment achievability (Health Canada, 2005). In Bangladesh, ground water contains $200 \mu \mathrm{g} / \mathrm{L}$ of arsenic compared to set limit of $10 \mu \mathrm{g} / \mathrm{L}$ and this ground water is extensively used for irrigation of crops, therefore there is potential increase in the 
concentration of arsenic in cultivated farm products such as cereal, rice and vegetables (Persson, 2002). Reports show that $75 \%$ of the total cropped area and $83 \%$ of total irrigated area are used for cultivating rice, however rice is well known to be the staple food in Bangladesh, hence most people eat rice at least twice a day or even more and rice straw is used as animal feed (for example goat, cow, pork, cattle and sheep) (Jannuzi \& Dey, 1999).

\subsubsection{Biomarker of Arsenic exposure}

The three most commonly employed biomarkers used to identify or quantify arsenic exposure are total arsenic in hair or nails, blood arsenic, and total or speciated metabolites of arsenic in urine. Because arsenic accumulates in keratin-rich tissues such as skin, hair and nails as a consequence of its affinity for sulfhydryl groups, arsenic levels in hair and nails may be used as an indicator of past exposure to arsenic (K. Jomova et al, 2011). Studies show the success in the use of hair, skin and nails as a biomarker of past arsenic exposure (Karagas, Morris, Weiss, \& Spate, 1996; Karagas, Stukel, \& Tosteson, 2002; Koons \& Peters, 1994; Paschal, Obar, \& Vallee, 1989; Wolfsperger, Hauser, \& Gößler, 1994). Blood arsenic, for example, is used as a biomarker only in cases of very recent exposure to arsenic or relatively high level of exposure (for example in the case of poisoning) and this is because inorganic arsenic is rapidly cleared from the blood (Aposhian \& Aposhian, 2006; S. Cohen et al., 2007; Suzuki et al., 2004).

\subsubsection{Arsenic metabolism}

One of the reactions involved in arsenic metabolism includes the oxidative methylation reactions, in which trivalent forms of arsenic are sequentially methylated to form mono-, di- and trimethylated products using S-adenosyl methionine (SAM), CYT19 or As-methyltransferase as the methyl donor (Figure 2) (Aposhian \& Aposhian, 2006). Glutathione (GSH) conjugation is the other reaction involved in the metabolism of arsenic and this involves 2 electron reduction of pentavalent arsenic 
to trivalent form and the methylation of arsenic in its trivalent form in the presence of GSH or other thiol compounds (K. Jomova et al, 2011).

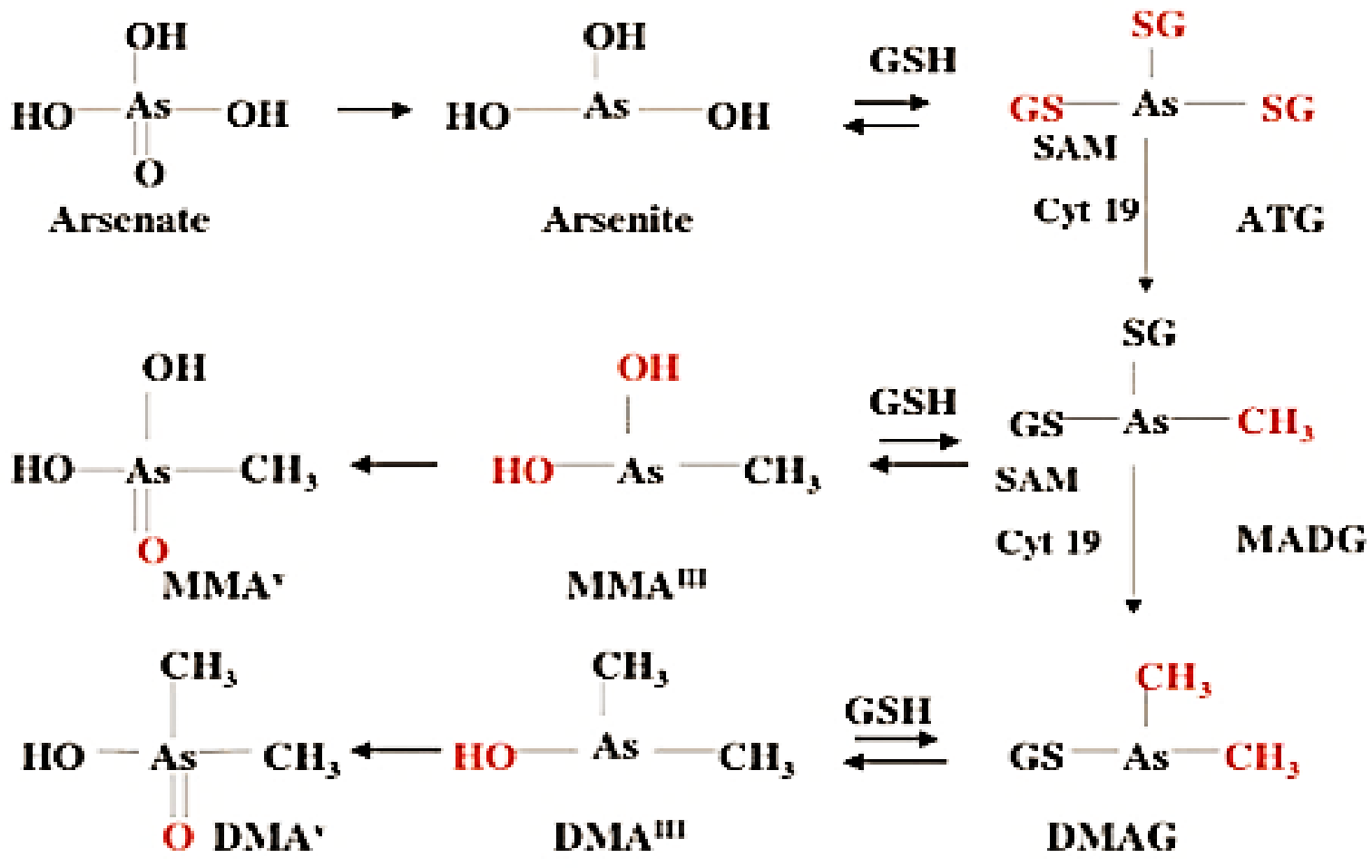

Figure 2: Mechanism involved in ars enic metabolism (Aposhian \& Aposhian, 2006)

\subsubsection{Arsenic toxicity}

Arsenic is classified by International Agency for Research on Cancer (IARC) as category 1 carcinogen to human, hence some of the mechanism proposed for arsenic carcinogenicity includes the induction of oxidative stress, genotoxicity, diminished DNA repair, altered DNA methylation patterns and enhanced cell proliferation (Schoen, Beck, Sharma, \& Dubé, 2004). The methylation of inorganic arsenic used to be described as a mechanism of detoxifying arsenic, but several recent studies have observed that methylated inorganic arsenic species, for example, methylated and dimethylated inorganic arsenite $\left(\mathrm{MMA}^{\mathrm{III}}\right.$ and $\left.\mathrm{DMA}^{\mathrm{III}}\right)$, are either as toxic as or much more 
cytotoxic, more genotoxic and more inhibitors of some enzyme activity than trivalent arsenic (Ghosh, Banerjee, Giri, \& Ray, 2008; Suzuki et al, 2004; Valko et al., 2005).

The toxicity of arsenic is largely dependent on dose and its bioavailability, that is, mechanisms of uptake through cell membranes, intracellular distribution and binding to cellular macromolecules (Hei, Liu, \& Waldren, 1998). Arsenite or trivalent arsenical (As (III)) are generally considered to be more toxic than the corresponding pentavalent arsenicals or arsenate (As (V)), since arsenite has high affinity for thiol groups of biomolecules, such as Glutathione (GSH) and cysteinerich proteins thereby causing cellular functions to deteriorate (Klaudia Jomova \& Valko, 2011). Pentavalent arsenicals are usually considered less toxic because they are in free form and do not bind to the thiol compounds. However, under anaerobic conditions, they are reduced to trivalent forms which binds to GSH and other thiols in the cell (Figure 2) (Klaudia Jomova \& Valko, 2011; Mizumura, Watanabe, Kobayashi, \& Hirano, 2010).

Due to the high affinity of trivalent arsenic for binding thio/sulfhydryl protein groups, arsenic inhibits several cellular enzyme activities such as pyruvate dehydrogenase (reducing the conversion of pyruvate to acetyl CoA), inhibits glucose uptake into the cell, causes the oxidation of fatty acid and causes the generation of glucose from non-carbohydrate carbon substrates (gluconeogenesis), thereby leading to the production of more acetyl CoA (K. Jomova et al., 2011). The toxicity of pentavalent arsenic is either by its reduction to trivalent arsenic or through its substitution for inorganic phosphate in glycolytic and cellular respiration pathways due to the resemblance of pentavalent arsenic and inorganic phosphate. This results in uncoupling of oxidative phosphorylation because of the formation of ADP-arsenate instead of the high energy ATP (D. Li, Morimoto, Takeshita, \& Lu, 2001). 


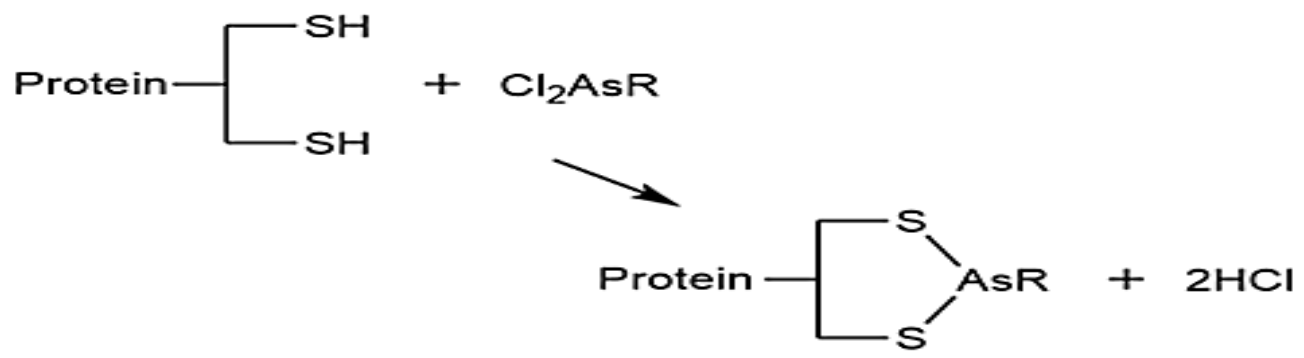

Figure 3: Binding of arse nite to sulphur containing group in protein (Mizumura et al., 2010)

Epidemiologic studies have revealed that chronic exposure to arsenic can result in liver injury, peripheral neuropathy and that inorganic arsenic is carcinogenic to human organs, including the lung, liver, skin, bladder, and kidney (IARC, 1987). Studies showed that low concentrations of arsenite in cultured mammalian cell lines (such as V79, CHO, A549) and in human peripheral lymphocytes causes the induction of micronuclei, chromosomal aberrations, DNA strand breaks and oxidative DNA base damage (Hei et al., 1998; Schoen et al., 2004). Therefore the role of arsenic in oxidative damages needs further research.

\subsubsection{Arsenic induced oxidative stress}

Arsenic induced oxidative stress is one of the prevailing and evidenced based mechanisms of arsenic toxicity. Arsenic-mediated generation of ROS is a complicated and an unclear mechanism which involves the formation of various $\mathrm{ROS}$ such as superoxide anion radical $\left(\mathrm{O}_{2}{ }^{-\bullet}\right)$, singlet oxygen $\left({ }^{1} \mathrm{O}_{2}\right)$, Nitric oxide $\left(\mathrm{NO}^{\bullet}\right)$, peroxyl radical $\left(\mathrm{ROO}^{\bullet}\right)$, hydrogen peroxides $\left(\mathrm{H}_{2} \mathrm{O}_{2}\right)$, dimethylarsinic peroxyl radicals $\left[\left(\mathrm{CH}_{3}\right)_{2} \mathrm{AsOO}^{\bullet}\right]$ and dimethylarsinic radical $\left[\left(\mathrm{CH}_{3}\right)_{2} \mathrm{As}{ }^{\bullet}\right]($ Figure 4) $($ Kitchin \& Conolly, 2010), however some studies have proposed the formation of intermediary arsine species regardless of the unclear mechanism (Matsui et al., 1999; K Yamanaka, Mizoi, \& Kato, 2001). In addition to ROS, arsenic exposure can also initiate the generation of RNS. Trivalent arsenic has been shown to inhibit the activity of glutathione, which protects the cell against oxidative damage, thereby 
leading to a disturbance in DNA repair system, hence contributing to an increased level of oxidative stress and damages in the cell (Figure 4) (Beyersmann \& Hartwig, 2008). Pentavalent arsenic is toxic and initiates oxidative stress because of its reduction to trivalent arsenic. High affinity of trivalent arsenic to thiol groups of protein has been observed to lead to mutations and DNA strand breaks. A study on mouse liver cells exposed to inorganic arsenic showed a decreases in antioxidant defenses such as a decrease in GSH, glucose-6-phosphate dehydrogenase, GSH reductase, catalase, and GSH peroxidase (Kitchin \& Conolly, 2010).

(Watanabe \& Hirano, 2013) explained one of the routes to produce hydrogen peroxides $\left(\mathrm{H}_{2} \mathrm{O}_{2}\right)$, which involves the oxidation of trivalent arsenic (As (III)) to pentavalent arsenic (As (V)) under physiological condition leading to the formation of $\mathrm{H}_{2} \mathrm{O}_{2}$ (a source of very reactive oxygen specie, hydroxyl radical):

\section{$\mathrm{H}_{3} \mathrm{AsO}_{3}+\mathrm{H}_{2} \mathrm{O}+\mathrm{O}_{2} \rightarrow \mathrm{H}_{3} \mathrm{AsO}_{4}+\mathrm{H}_{2} \mathrm{O}_{2} \Delta \mathrm{rG}=-40.82 \mathrm{kcal} / \mathrm{mol}$ Trivalent arsenic Pentavalent arsenic \\ Equation 5}

Hydrogen peroxide $\left(\mathrm{H}_{2} \mathrm{O}_{2}\right)$ is not a free radical but as shown in Section 2.1.1.3., in the presence of a metal catalyst, for example Iron $(\mathrm{Fe}), \mathrm{H}_{2} \mathrm{O}_{2}$ is decomposed into highly reactive hydroxyl radical. Another proposed mechanism for arsenic-induced ROS generation is the reduction of molecular oxygen by trivalent arsenic (As (III)) leading directly to the generation of $\mathrm{H}_{2} \mathrm{O}_{2}$ and/or formation of arsenic peroxyly radical shown to play a major role in DNA damage (Figure 4) (Kenzo Yamanaka et al., 1990). 8-hydroxyguanine (8-OH-G) is the most extensively studied DNA lesion and it is one of the products of DNA oxidation from the reaction of hydroxyl radical with guanine (G) base of the DNA (K. Jomova et al., 2011). Many studies have confirmed the generation of free radicals during arsenic metabolism in cells that could lead to formation of 8-hydroxy-2-deoxyguanosin (8OHdG) which is a sensitive marker to ROS-based DNA damage and could cause mutation at DNA 
replication (Ding, Hudson, \& Liu, 2005). Several other markers are used are used to determine arsenicinduced oxidative stress (Figure 4). A study by (Matsui et al., 1999) showed that the formation of ROS during arsenic metabolism is involved in the formation of arsenic-induced skin cancer by using 8hydroxy-2-deoxyguanosin $(8-\mathrm{OHdG})$ as the marker.

Arsenic-induced oxidative stress has been shown to affect a number of receptors and genes, including growth factor receptors, mitogen-activated protein kinases, and nuclear transcription factors NF-nB, AP-1, p53, NFAT, and HIF-1 (Henkler et al., 2010; Leonard et al., 2004).

A study done by Nordenson \& Beckman suggested that in lymphocytes, sister chromatid exchanges are mediated by oxygen free radicals (Nordenson \& Beckman, 1991). The authors observed that the addition of superoxide dismutase (SOD) and catalase (CAT) to lymphocyte cultures reduced the number of arsenic-induced sister chromatid exchanges. Another study observed that sodium arsenite increases the generation of ROS in a dose-dependent manner in a study done using mouse aortic endothelial cell line. In the study, sodium arsenite initiated a ROS-mediated activation of the c-Jun Nterminal kinases (JNK) signalling pathway, which is a member of mitogen-activated protein kinase (MAPK) family that functions to regulate a range of biological processes implicated in tumorigenesis and neurodegenerative disorders (Davies \& Tournier, 2012). ROS-mediated activation of JNK resulted in the upregulation of the expression of angiotens in II Type I receptor (AT $\left.{ }_{1} \mathrm{R}\right)$ (Hossain et al., 2013).

Overall, arsenic-induced ROS generation has been linked to a variety of cardiovascular diseases and cancer. Several studies have shown how antioxidant enzymes such as glutathione peroxidase, superoxide dismutase and catalase has been used as treatment for the arsenic induced genotoxicity (Hei et al., 1998; Nordenson \& Beckman, 1991; T. S. Wang, Shu, Liu, Jan, \& Huang, 1997), however there has been no prior research on the use of hydrolyzed oat bran protein as a form of natural antioxidant to treat arsenic-induced oxidative stress, hence the purpose of this research. 


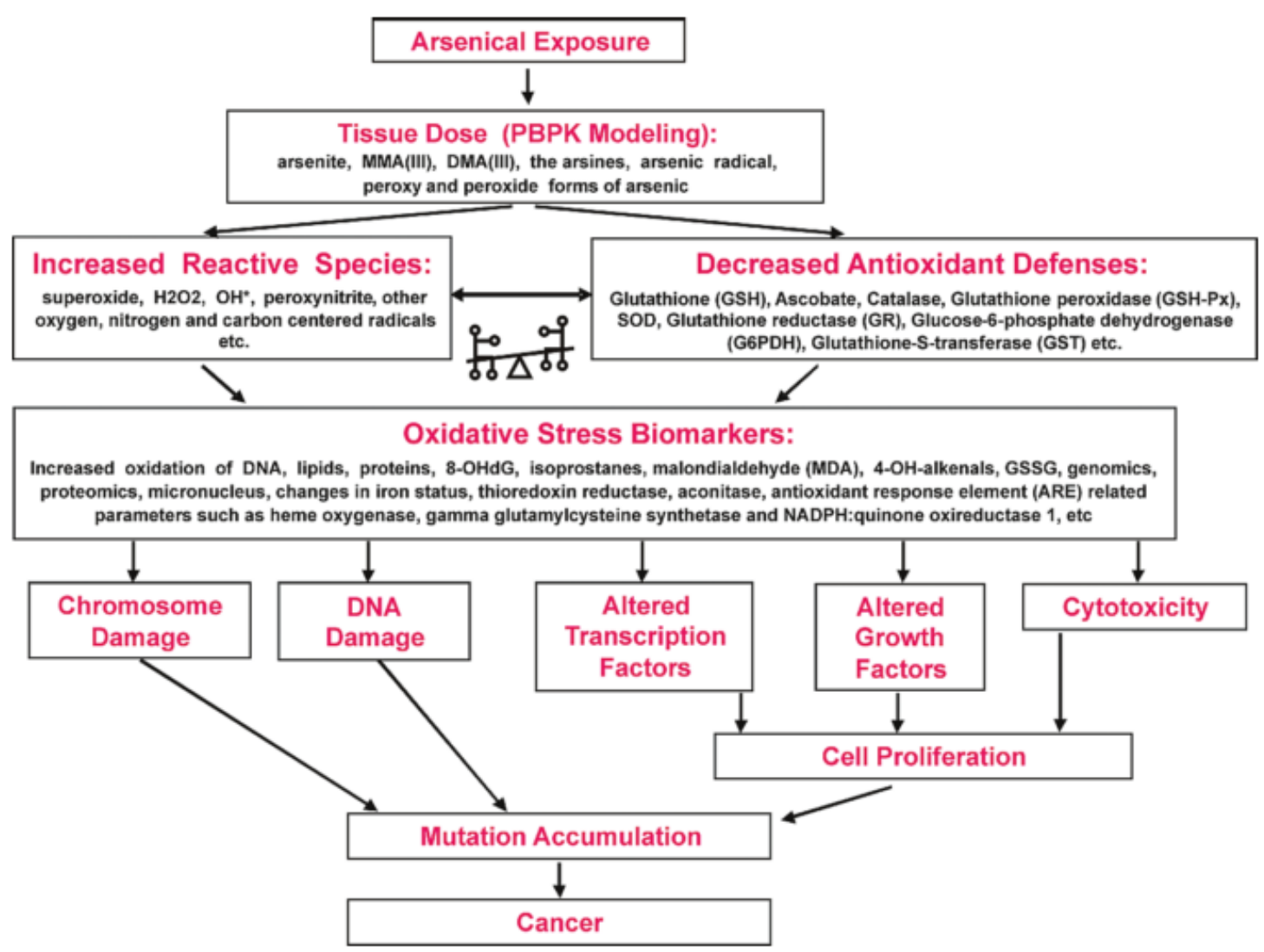

Figure 4: Summary of mechanis ms involved in arsenic-induced oxidative stress leading to cancer (Kitchin \& Conolly, 2010)

\subsubsection{Chromium}

Chromium is one of the most common toxic metalloid that is widely distributed in the earth's crust. It is the $24^{\text {th }}$ element of the periodic table which exists in 8 different valence or oxidation state: $-2,-1,0,+1$, $+2,+3,+4,+5$ and +6 , with trivalent $(\mathrm{Cr}[\mathrm{III}])$ and hexavalent $(\mathrm{Cr}[\mathrm{VI}])$ chromium as the most common state occurring naturally in the environment and $\mathrm{Cr}(\mathrm{III})$ is the most stable forms. Chromium is a bluewhite coloured compound and it is used in several industrial and domestic purposes such as in pigment manufacturing, painting, leather tanning, steel wielding, metal or chromium plating (Henkler et al., 2010). Hexavalent chromium (Cr [VI]) is classified by International Agency for Research on Cancer (IARC) as Group 1 human carcinogen while trivalent chromium $(\mathrm{Cr}[\mathrm{III}])$ is classified as Group 3 carcinogen because it plays a key role in the carcinogenesis of hexavalent chromium (Bonde \& 
Christensen, 1991), however trivalent chromium is an essential dietary mineral but in low doses, as it is useful in normalizing blood glucose level, regulating carbohydrate and lipid metabolism and potentiate insulin and insulin binding in the system (R. A. Anderson, 1986; Codd, Dillon, Levina, \& Lay, 2001).

\subsubsection{Sources and exposure to chromium}

The main sources of exposure to chromium are through occupational exposure (paint pigment, dyes, leather tanning, stainless steel additive, chrome plating), dietary exposure (romaine lettuce, onions , potatoes, milk and dairy products, meat, cereals, fruits, tomatoes and seafood) and environmental exposure (groundwater/drinking water, soil) (Bates \& Baqi, 2015). Chromium was found present in Canadian soils at concentrations ranging from 20 to $125 \mathrm{mg} / \mathrm{kg}$ (Health Canada, 2008). A survey by Health Canada on the level of chromium in Canadian drinking water supplies showed that the concentration of chromium in raw water and distributed treated water are 14 and $9 u g / L$ respectively. A maximum acceptable concentration for chromium in drinking water has been set as $0.05 \mathrm{mg} / \mathrm{L}(50 \mu \mathrm{g} / \mathrm{L})$ on the basis of health considerations by world Health Organization (WHO).

Chromium is present in food mainly in the trivalent form, but some food products contain more hexavalent than trivalent forms. Cooked food has been observed to contain slightly higher levels of chromium compared to raw food products because of chromium contribution from stainless steel utensils (Fawell \& Lund, 1996). The levels of chromium in food products varies; Canadian food survey has observed in average levels; milk and dairy products $(0.06 \mathrm{mg} / \mathrm{kg})$, meat $(0.07 \mathrm{mg} / \mathrm{kg})$, cereal $(0.17$ $\mathrm{mg} / \mathrm{kg})$, potatoes $(0.05 \mathrm{mg} / \mathrm{kg})$, fruits $(0.06 \mathrm{mg} / \mathrm{kg})$, sugars $(0.34 \mathrm{mg} / \mathrm{kg})$ and seafood (ranging between 0.13 to $0.85 \mathrm{mg} / \mathrm{kg}$ ) as the main dietary sources of chromium (Health Canada, 2008). Imported and domestic wines commercially available in Canada were also found to contain chromium concentration between 0.02 and $0.06 \mathrm{mg} / \mathrm{L}$ (Health Canada, 2008). 


\subsubsection{Biomarkers of chromium exposure}

Hair, urine and blood chromium levels are the most employed biomarkers used to identify the level of exposure to chromium. An epidemiological study done in Greece used the chromium levels in blood and hair to determine the exposure level to chromium in drinking water (Sazakli et al., 2014). Several other studies has been done to support the use of urine, blood and hair in determining the level of exposure to hexavalent or trivalent chromium species either occupationally, environmentally or through diet (Bonde \& Christensen, 1991; Kortenkamp, 1997; Stern et al, 1992; Werfel, Langen, Eickhoff, \& Schoonbrood, 1998).

\subsubsection{Chromium metabolism}

One of the mechanisms involved in chromium metabolism includes the reduction of hexavalent chromium (Cr (VI)) first to pentavalent chromium ( $\mathrm{Cr}(\mathrm{V}))$, then to tetravalent chromium $(\mathrm{Cr}(\mathrm{IV}))$ and finally to trivalent chromium ( $\mathrm{Cr}$ (III)) by intracellular non-enzymatic and enzymatic reductants (Tsopmo et al., 2014). Non-enzymatic reductant such as ascorbate (Asc) which is a cellular reducing agent mainly produces abundance of $\mathrm{Cr}$ (IV) as intermediates in the reduction of $\mathrm{Cr}$ (VI) to $\mathrm{Cr}$ (III) (Bonde \& Christensen, 1991). Hexavalent chromium can also be reduced to trivalent chromium by thiolbased reducing agents such as glutathione; however $\mathrm{Cr}(\mathrm{V})$ and $\mathrm{Cr}(\mathrm{IV})$ are produced as intermediates (Luczak, Green, \& Zhitkovich, 2015). Several in vitro studies has confirmed that other substances such as cysteine, lipoic acid, NADPH, fructose, ribose etc. can reduce $\mathrm{Cr}$ (VI) to $\mathrm{Cr}$ (III) once it is in the cell (Valko et al., 2006a).

\subsubsection{Chromium toxicity}

Chromium toxicity depends mostly on the exposure dose and its biological availability in the cell, which includes its uptake through cell membranes, intracellular distribution and binding of chromium to intracellular macromolecules (Léonard \& Lauwerys, 1980). Several studies have shown some of the 
mechanisms involved in chromium toxicity to include DNA damage, Apoptotic cell death, altered gene expression and induction of oxidative stress (Debasis Bagchi, Stohs, Downs, Bagchi, \& Preuss, 2002). There have been several debates and researches done in order to determine the particular species of chromium involved in cellular damage and the mechanisms involved in chromium-induced genotoxicity. Hexavalent chromium (Cr (VI)) compounds are considered to be highly toxic (i.e. carcinogenic) compared to trivalent chromium ( $\mathrm{Cr}(\mathrm{III}))$ because negatively charged chromate ions $\left(\mathrm{CrO}_{4}{ }^{2-}\right)$ are structurally similar to sulphate $\left(\mathrm{SO}_{4}{ }^{2-}\right)$ and hydrogen phosphate $\left(\mathrm{PO}_{4}{ }^{3-}\right)$ anions, so they can be transported across cellular membranes through nonspecific anion carriers or anion transporters such as regular $\mathrm{SO}_{4}{ }^{2-}$ and $\mathrm{PO}_{4}{ }^{3-}$ carriers (Poljšak et al., 2005). Once $\mathrm{Cr}$ (VI) is in the cell, in the presence of physiological reductants such as glutathione and ascorbate, it causes varieties of DNA lesions such as Cr-DNA adducts, DNA-protein crosslinks, DNA-DNA crosslinks and induces oxidative damages (Henkler et al., 2010). Cr (III) is generally considered non-toxic, however classified by IARC as Group 3 carcinogen as previously mentioned and when present in raw water, it can be oxidized to $\mathrm{Cr}$ (VI) during chlorination (Health Canada, 2008). Chromium (VI) was observed to induce the activation of $\mathrm{AP}-1$ protein in a time and dose - response manner, however, chromium (VI) was also found to activate MAPKs p38 and JNK in human lung cancer cell line (Leonard et al., 2004). A study by (Kortenkamp, 1997) reacted isolated DNA with $\mathrm{Cr}(\mathrm{VI}) /$ glutathione system in the presence of $\mathrm{O}_{2}$ and they noticed DNA damages such as DNA strand breaks and $\mathrm{Cr}$ (III)-DNA complexes similar to those observed in isolated DNA reacted with $\mathrm{Cr}(\mathrm{VI})$ /ascorbate system. Another study observed DNA damages such as DNA strand breaks and Cr(III)-DNA complexes in cell cultures and living organisms that were exposed to Cr(VI) (M. D. Cohen, Kargacin, Klein, \& Costa, 1993). The fate of Cr (VI) in the cell is mainly dependent on its intracellular redox activity and it has been shown to induce different oxidative damages (Figure 4). 


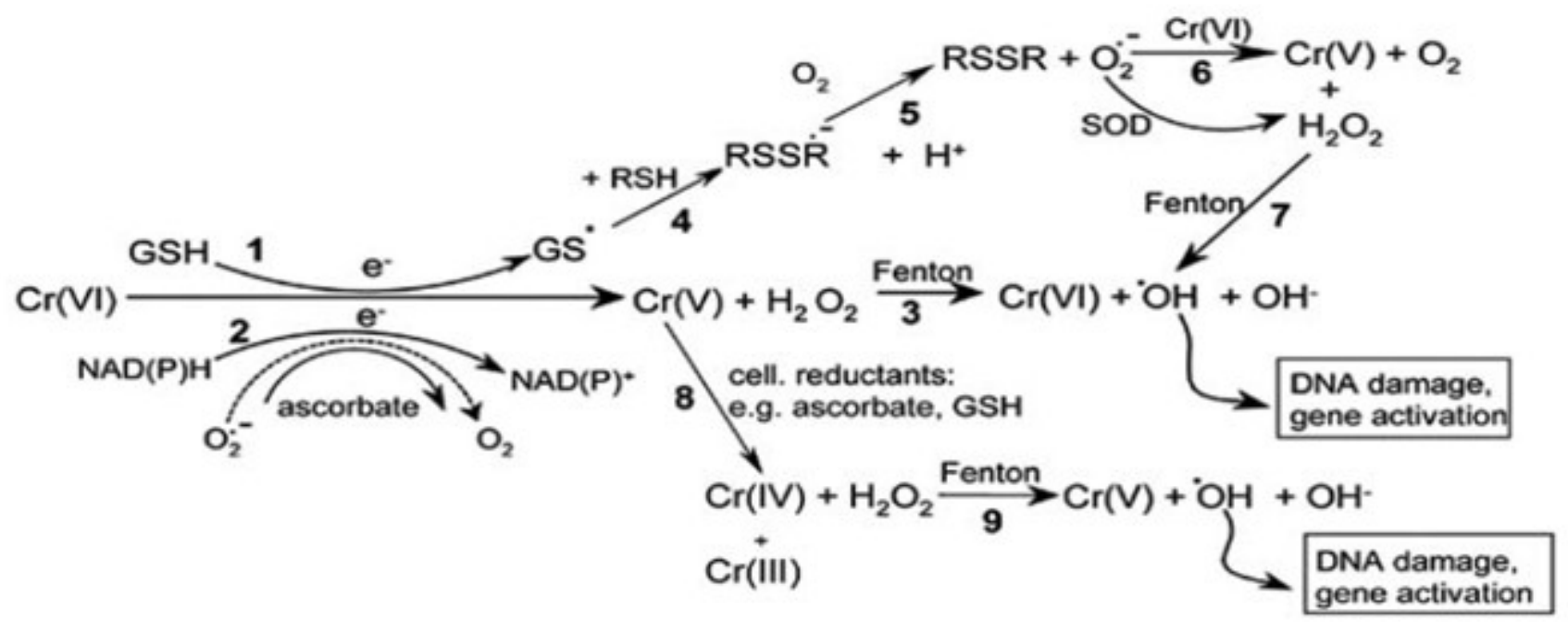

Figure 5: Biological mechanism of Chromium (VI) and Cr-induced oxidative stress (Valko et al., 2006a)

\subsubsection{Chromium induced oxidative stress}

Chromium induced oxidative stress is one of the mechanisms of chromium toxicity that is still on debate. Chromium-mediated generation of free radical is a complicated and an unclear mechanism which involves the formation of various $\mathrm{ROS}$ such as superoxide anion radical $\left(\mathrm{O}_{2}{ }^{-\bullet}\right)$, singlet oxygen $\left({ }^{1} \mathrm{O}_{2}\right)$, peroxyl radical $\left(\mathrm{ROO}^{\bullet}\right)$ and hydrogen peroxides $\left(\mathrm{H}_{2} \mathrm{O}_{2}\right)$ (Figure 5) (Valko et al., 2005). Similar to arsenic exposure, chromium exposure can also mediate the generation of RNS. Chromium species has been shown to bind to glutathione and other thiol molecules, thus inhibiting the activity of glutathione leading to a disturbance in DNA repair system and production of highly reactive oxygen species (Figure 5), and contributing to an increased level of oxidative stress and damages in the cell (Aiyar, Berkovits, Floyd, \& Wetterhahn, 1991).

Once chromium (VI) has been internalized in the cells through anion channels/carriers, it is initially reduced to $\mathrm{Cr}(\mathrm{V})$ by ascorbate or glutathione which results in the formation of glutathionethiyl radicals $\left(\mathrm{GS}^{\bullet}\right)$ that can further reduce molecular oxygen or react with other thiol in an oxygenated tissue, hence producing superoxide radicals which could be dismutated into hydrogen peroxide as shown 
in equation 6 (M. D. Cohen et al., 1993). Using electron paramagnetic resonance (EPR) spectroscopy, a study was able to demonstrate the formation of $\mathrm{Cr}(\mathrm{V})$ species and $\mathrm{GS}{ }^{\bullet}$ from the reaction of chromium (VI) with GSH (S. Liu \& Dixon, 1996).

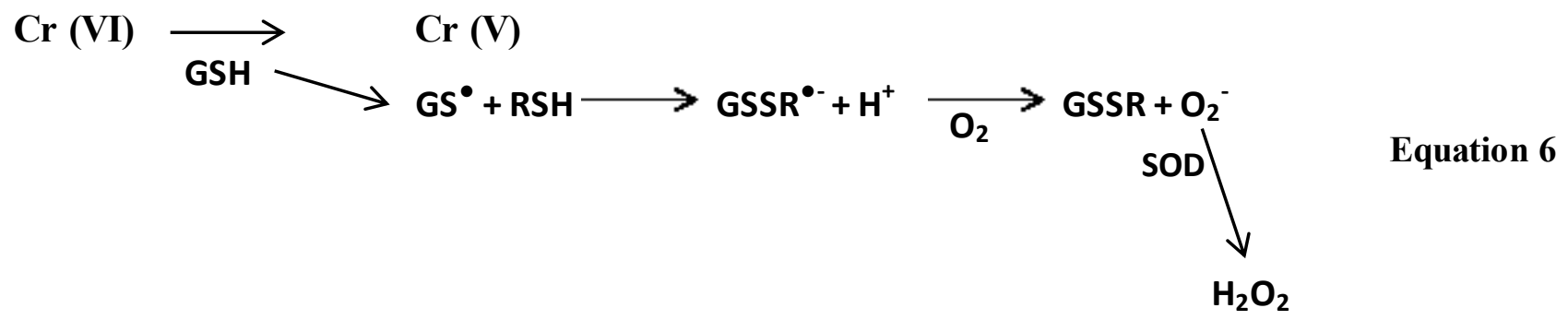

Chromium (V) formed from the reaction of GSH with $\mathrm{Cr}(\mathrm{VI})$, is further reduced to $\mathrm{Cr}(\mathrm{IV})$ by biological reductants such as ascorbate (Asc) or GSH which can form $\mathrm{GS}^{\bullet}$, hence resulting in further production of ROS (X Shi \& Dalal, 1994). Chromium (V) and chromium (IV) can each react with endogenous hydrogen peroxides $\left(\mathrm{H}_{2} \mathrm{O}_{2}\right)$ to gain an electron, hence forming $\mathrm{Cr}(\mathrm{VI})$ and $\mathrm{Cr}(\mathrm{V})$ respectively via Fenton reaction, and further producing DNA damaging hydroxyl radicals $\left({ }^{\bullet} \mathrm{OH}\right)$ as shown in the equation 7 (Debasis Bagchi et al, 2002). Chromium-mediated generation of hydroxyl radicals $\left({ }^{\bullet} \mathrm{OH}\right)$ can also occur through Haber-Weiss reaction which is dependent on endogenous superoxide anion radical $\left(\mathrm{O}_{2}^{-}\right)$and hydrogen peroxides $\left(\mathrm{H}_{2} \mathrm{O}_{2}\right)(\mathrm{X}$ Shi, Leonard, Liu, Zang, \& Gannett, 1998)

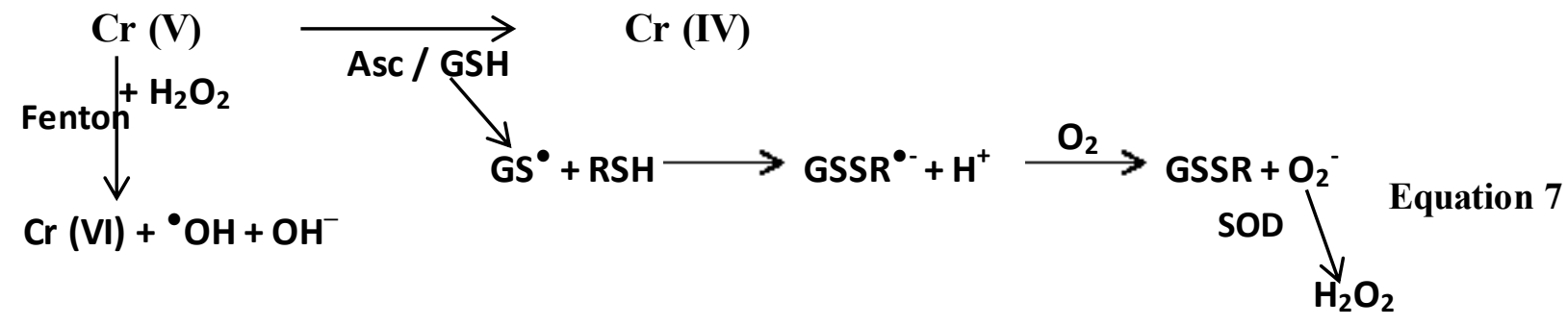

Chromium (VI) is then reduced and accumulated as the final stable product, chromium (III) or trivalent chromium which results in the formation of $\mathrm{Cr}$ (III)-DNA adducts due to the series of one-electron 
reduction of $\mathrm{Cr}(\mathrm{VI})$ that has generated various reactive oxygen species which could be potential target and damage to DNA molecules (Figure 5) (Poljšak et al., 2005).

A study observed that after orally administering water containing chromium (VI) to rats, there was an increase in markers of oxidative stress such as hepatic DNA damage, hepatic lipid peroxidation, enhanced urinary malondialdehyde, formaldehyde, acetaldehyde, acetone and propionaldehyde over a 90 days period (D. Bagchi, Hassoun, Bagchi, Muldoon, \& Stohs, 1995). A lot of the toxicity induced by chromium is mediated by ROS generated from chromium metabolism. Studies have confirmed the generation of free radicals during $\mathrm{Cr}(\mathrm{VI})$ metabolism in cells that could lead to formation of 8-hydroxy2-deoxyguanosin $(8-\mathrm{OH}-\mathrm{dG})$ (formed from the reaction of $\bullet \mathrm{OH}$ with guanine) which is a sensitive marker to ROS-induced DNA damage and could cause mutation at DNA replication (Kakkar \& Jaffery, 2005; Xianglin Shi \& Dalal, 1989).

Normal human lung fibroblast (HLF) cells were treated with $\mathrm{Cr}$ (VI) and its effect was compared to HLF cells pre-treated with ascorbic acid (vitamin C) and tocopherol (vitamin E). It was observed that $\mathrm{Cr}$ (VI) caused the HLF cells to undergo about $20 \%$ apoptosis and an increased level of p53 induction. It was observed that pre-treatment of the cells with vitamin $\mathrm{C}$ had no effect on p53 induction after chromium (VI) treatment and none of the two vitamins had an effect on Cr-DNA adduct formation. However, pre-treatment of the cells with vitamin $\mathrm{C}$ and vitamin $\mathrm{E}$ was shown to alter the spectrum of cellular and/or genetic lesions induced by chromium (VI) (Carlisle et al, 2000). In a different study, yeast cells were pre-treated with ascorbic acid (vitamin C) and the antioxidant effect of the vitamin $\mathrm{C}$ was investigated on chromium-induced DNA damage in the cells. It was shown that ascorbic acid influenced chromium (VI) toxicity both as a reducing agent, by decreasing $\mathrm{Cr}(\mathrm{V})$ persistence, and as an antioxidant, by decreasing intracellular superoxide anion and hydrogen peroxide formation and by scavenging free radicals formed during $\mathrm{Cr}(\mathrm{VI})$ to $\mathrm{Cr}$ (III) reduction, hence decreased cytotoxicity and genotoxicity in ascorbic acid pre-treated cells (Poljšak et al, 2005). Several forms of 
antioxidants have been researched in treatment of damages incurred by metal-induced oxidative stress (Aiyar et al., 1991; Stearns, Courtney, \& Giangrande, 1994).

\subsection{Antioxidants}

The effect of reactive oxygen species (ROS) and reactive nitrogen species (RNS) is balanced by cellular antioxidant defense mechanism through enzymatic or non-enzymatic reactions. These antioxidants quench free radicals (pro-oxidants), chelates/ scavenge redox metals and slow down or prevent oxidative stress. Enzymatic antioxidants includes superoxide dismutase (SOD), glutathione peroxidase (GSH peroxidase or GPx), and catalase (CAT) while the non-enzymatic antioxidants includes Vitamin C, Vitamin E, reduced glutathione, carotenoids and other molecules in foods (TPA et al., 2004; Valko, Rhodes, Moncol, Izakovic, \& Mazur, 2006b).

SOD is one of the most effective intracellular enzymatic antioxidants that catalyze the dismutation of superoxide anion $\left(\mathrm{O}_{2}^{-\bullet}\right)$ to a less reactive specie, hydrogen peroxide $\left(\mathrm{H}_{2} \mathrm{O}_{2}\right)$ then to oxygen $\left(\mathrm{O}_{2}\right)$ as shown in equation 2 in section 2.1.1.2 (Halliwell \& Gutteridge, 2015). There are three forms of SOD and they are classified based on the metal it requires to function; cytosolic $\mathrm{Cu} / \mathrm{Zn}-\mathrm{SOD}$, $\mathrm{Fe} / \mathrm{Mn}$-SOD and Ni-SOD. Hydrogen peroxide generated from the action of SOD is further converted to water and molecular oxygen by Catalase which is an enzyme present in cells of plants, animals and aerobic bacteria (T. S. Wang et al, 1997). Catalase helps control the level of $\mathrm{H}_{2} \mathrm{O}_{2}$ in the cells. Glutathione peroxidase (GPx) is an enzyme with peroxidase activity, however GPx has two forms, Seleniumdependent GPx and selenium-independent (glutathione-S-transferase, GST) (Valko et al., 2006a). Selenium-dependent GPx converts $\mathrm{H}_{2} \mathrm{O}_{2}$ to water and oxygen, at the same time oxidizes GSH which results in the generation of glutathione disulfide (GSSG) as shown in equation 8. GPx also decomposes or detoxifies hydroperoxides $(\mathrm{LOOH}, \mathrm{ROOH})$ by converting them to water or alcohol as shown in equation 9 (Y. Fang, Yang, \& Wu, 2015). 


\begin{tabular}{|rccc|l|}
\hline 2GSH & $\mathrm{H}_{2} \mathrm{O}_{2} \underset{\mathrm{GPx}}{\longrightarrow}$ & GSSG $+2 \mathrm{H}_{2} \mathrm{O}$ & Equation 8 \\
\hline $2 \mathrm{GSH}+\mathrm{ROOH} \underset{\mathrm{GPx}}{\longrightarrow}$ & GSSG + ROH $+\mathrm{H}_{2} \mathrm{O}$ & Equation 9 \\
\hline
\end{tabular}

Vitamins are non-enzymatic antioxidants that directly scavenge ROS by donating an electron to the free radicals and it also upregulate the activities of antioxidant enzymes. Vitamin E for example is one of the most important antioxidants and is fat soluble, hence prevents the generation of ROS-induced peroxyl radicals thereby protecting the cells against lipid peroxidation (Aruoma, 1998). In a study conducted by (Muller, 1990), it was observed that a dietary deficiency in vitamin E resulted in the reduction in the activity of hepatic Catalase, GSH reductase and GSH peroxidase hence inducing liver and lipid peroxidation thereby causing neurological and cardiovascular disorder (Yagi, 1987; Young \& Woodside, 2001). Vitamin $\mathrm{C}$ is one of the most important water soluble antioxidants that work in aqueous part of the body. Its main function in the body is to protect thiol group of proteins against oxidation, however vitamin $\mathrm{C}$ works in combination with vitamin $\mathrm{E}$, carotenoids and enzymatic antioxidants to protect against ROS-induced oxidative damage (Carr, Zhu, \& Frei, 2000). In addition to vitamins, there are several other molecules in foods that contribute to the maintenance of cellular redox balance, prevent or retard the oxidative deterioration of food products. Sources of such molecules vary but some include fruits and vegetables, legumes, and cereals. The focus of the work is on cereals, specifically oats as sources of peptides to reduce ROS generation in model systems, chelate or convert toxic metal to stable forms.

\subsection{Cereals}

The term cereal is used to designate any grass cultivated mainly for the edible components of its grains known as caryopsis and consist of the endosperm, germ and bran(Butt et al., 2008). Cereals grains are grown in large quantities and provides more food energy worldwide than any other type of crop 
(Koehler \& Wieser, 2013). They are therefore amongst the most important staple foods to mankind but also a main constituent in animal feeds (Koehler \& Wieser, 2013). They are rich source of vitamins, minerals, carbohydrates, fats, oils, and proteins. Major cereals are wheat, corn, rice, barley, sorghum, millet, oats and rye in order of production (Butt et al., 2008). Figure 6 shows the evolutionary development (phylogeny) of cereal grains.

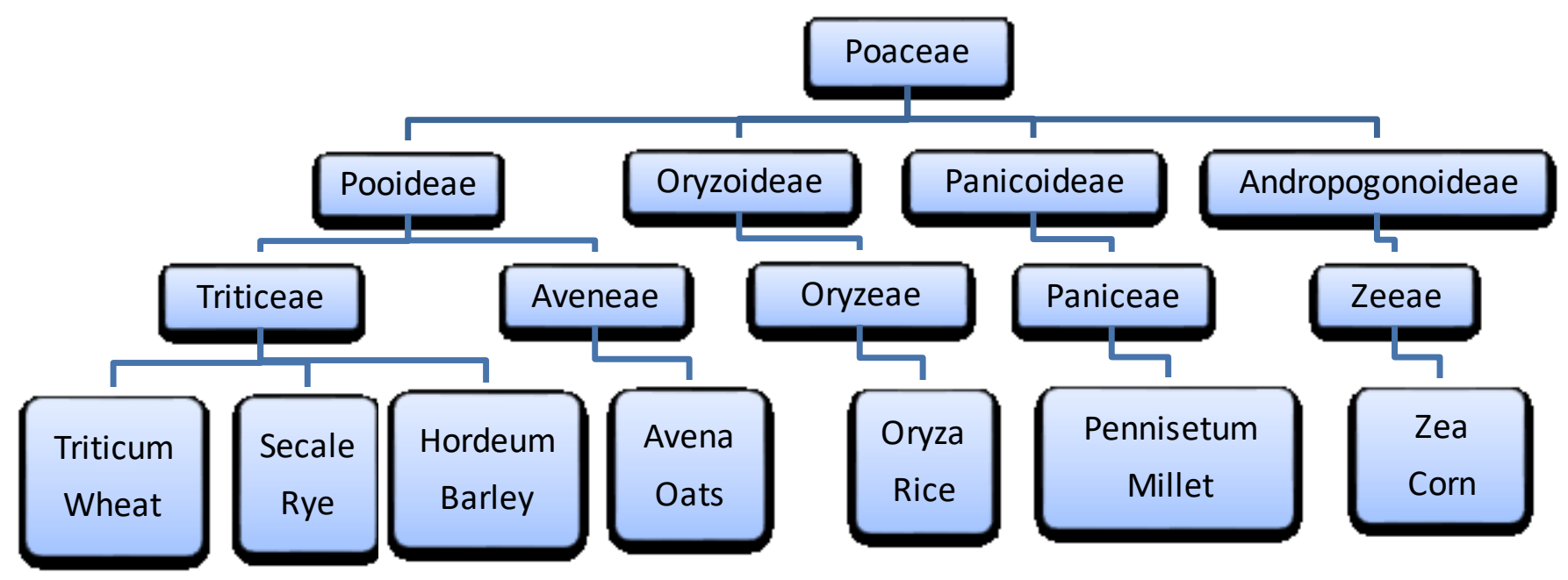

Figure 6 : Phylogeny of Cereal Grains. Adapted from (McGrew \& Chambers, 2012)

\subsubsection{Cereal Production}

Cereal supply almost one third of the total protein in human diet in Canada and United States (Kent \& Evers, 1994). They are grown on nearly $60 \%$ of the cultivated land in the world. According to a survey by the Food and Drug Organization in 2014, Rice, corn and Wheat take up the greatest part of land cultivated with cereals and produce the largest quantities of cereal grains (FAO, 2014) (Table 3 \& 4). Cereals are planted annually, with one harvest per planting. However, different cereals grains grow at different climatic conditions. Some grow in warm-seasons (e.g. rice, corn, millet and sorghum) while others are grown in cool-seasons (e.g. wheat, barley, oats and rye) (Koehler \& Wieser, 2013). 
Table 3: World Cereal production; cultivated area 2010 - 2014 (FAO, 2014)

\begin{tabular}{|c|ccccc|}
\hline & \multicolumn{5}{|c|}{ Cultivated Area (million ha) } \\
\hline Cereal Species & 2010 & 2011 & 2012 & 2013 & 2014 \\
\hline Barley & 47 & 48 & 49 & 49 & 49 \\
Maize (Corn) & 163 & 171 & 179 & 186 & 185 \\
Millet & 36 & 34 & 31 & 31 & 31 \\
Oats & 9 & 10 & 10 & 10 & 10 \\
Rice & 161 & 162 & 162 & 164 & 163 \\
Rye & 5 & 5 & 5 & 6 & 5 \\
Sorghum & 42 & 42 & 39 & 43 & 45 \\
Triticale & 4 & 4 & 4 & 4 & 4 \\
Wheat & 215 & 220 & 219 & 218 & 220 \\
\hline
\end{tabular}

Table 4: World Cereal production; grain production 2010 - 2014 (FAO, 2014)

\begin{tabular}{|c|ccccc|}
\hline & \multicolumn{5}{|c|}{ Grain Production (million tons) } \\
\hline Cereal Species & 2010 & 2011 & 2012 & 2013 & 2014 \\
\hline Barley & 123 & 133 & 132 & 143 & 144 \\
Maize (Corn) & 851 & 887 & 873 & 1014 & 1038 \\
Millet & 32 & 27 & 27 & 26 & 28 \\
Oats & 20 & 23 & 21 & 24 & 23 \\
Rice & 701 & 722 & 733 & 739 & 741 \\
Rye & 12 & 13 & 15 & 17 & 15 \\
Sorghum & 60 & 57 & 57 & 61 & 69 \\
Triticale & 14 & 14 & 14 & 14 & 17 \\
Wheat & 642 & 697 & 673 & 711 & 729 \\
\hline
\end{tabular}

\subsubsection{Chemical composition of cereals}

Cereal grains are mainly characterized by their high content of carbohydrates $(66-76 \%)$, mainly starch which amounts to $56-74 \%$ and fibre, $2-13 \%$. Moisture contents are $11-14 \%$, proteins $7-11 \%$, lipids $2-4 \%$, and minerals $1-3 \%$ (Kent \& Evers, 1994). Structures and quantities of chemical 
constituents in cereal grains differ by species, hence the difference in qualities of products made from cereal grains. This project focuses specifically on oat grains.

\subsection{Oats}

Oat plant consists of leaves and shortened stems like rosette type plants, which later terminates into large panicles that bear flowers and seeds or kernels. The oat kernel is also called the caryopsis or groats. It is elongated - spindle shaped, generally covered with fine, silky hairs and consists of the seed coat layers of cells, starchy endosperm and the embryo (Butt et al., 2008). Table 5 shows the taxonomic information of the oat plant. Grains have different nutritional properties, but Oat (Avena sativa) is distinct due to its multifunctional characteristic, nutritional properties and medicinal value (C. Chen, Milbury, Kwak, \& Collins, 2004). Whole oats are good source of protein, fibre, minerals and antioxidants. Oats are part of human diet and they are consumed in the form of flour, oatmeal, bran and oat rolled (mainly in breakfast cereals) or added to other food products.

\subsubsection{Oat Production and Distribution}

Oat was ranked 7th (Table 3) in the 2014 world cereal production statistics after wheat, corn (or maize), rice, barley and sorghum (FAO, 2014). Oat grains are mainly cultivated in temperate regions of the world. Russia, Canada and United States of America are the predominant oat producer, while Argentina, Australia, Finland and Sweden are the highest exporters of oats (Strychar, Webster, \& Wood, 2011). They are staple foods in Germany, Ireland, Scotland, and the Scandinavian countries. Several studies have shown that oat is traditionally used as a medicine to improve cognitive performance and mental health, reduces low density lipoprotein (LDL) as well as total cholesterol (Ahmed et al., 2013; Singh, De, \& Belkheir, 2013). 
Table 5: Taxonomic information of common oat (Butt et al., 2008)

\begin{tabular}{|ll|}
\hline Botanical name & Avena sativa \\
\hline Kingdom & Plantae: plants \\
Subkingdom & Tracheobionta: vascular plants \\
Super-division & Spermatophyta: seed plants \\
Division & Magnoliophyta: flowering plants \\
Class & Liliopsida: monocotyledons \\
Subclass & Commelinidae \\
Order & Cyperales \\
Family & Poaceae: grass family \\
Genus & Avena: oat \\
Species & A. sativa: common oat, A. byzantina, \\
\hline
\end{tabular}

\subsubsection{Anatomy of Oat}

The oat grain (Figure 7) consists of the apex, hull, bran, endosperm and the germ or embryo. The hull contains about $25-30 \%$ of the seed, which mostly comprises of cellulose, hemicellulose, lignin and about $2 \%$ of phenolic compounds (Butt et al., 2008; Klose \& Arendt, 2012). The oat kernel mainly consists of $38-40 \%$ bran, $55.8-68.3 \%$ endosperm, and 3\% germ. The starchy endosperm is the primary source of nutrient used by the embryo during germination and it is also the primary storage site for starch, proteins, lipids and $\beta$-glucan (predominant) (Klose \& Arendt, 2012). Germ contains the highest amount of proteins compared to other physiological parts of the kernel; however, it accounts for only $3 \%$ of the total weight of the kernel. The germ contain phytic acids, small amounts of calcium magnesium, manganese, and iron (Ekholm, Virkki, Ylinen, \& Johansson, 2003). 


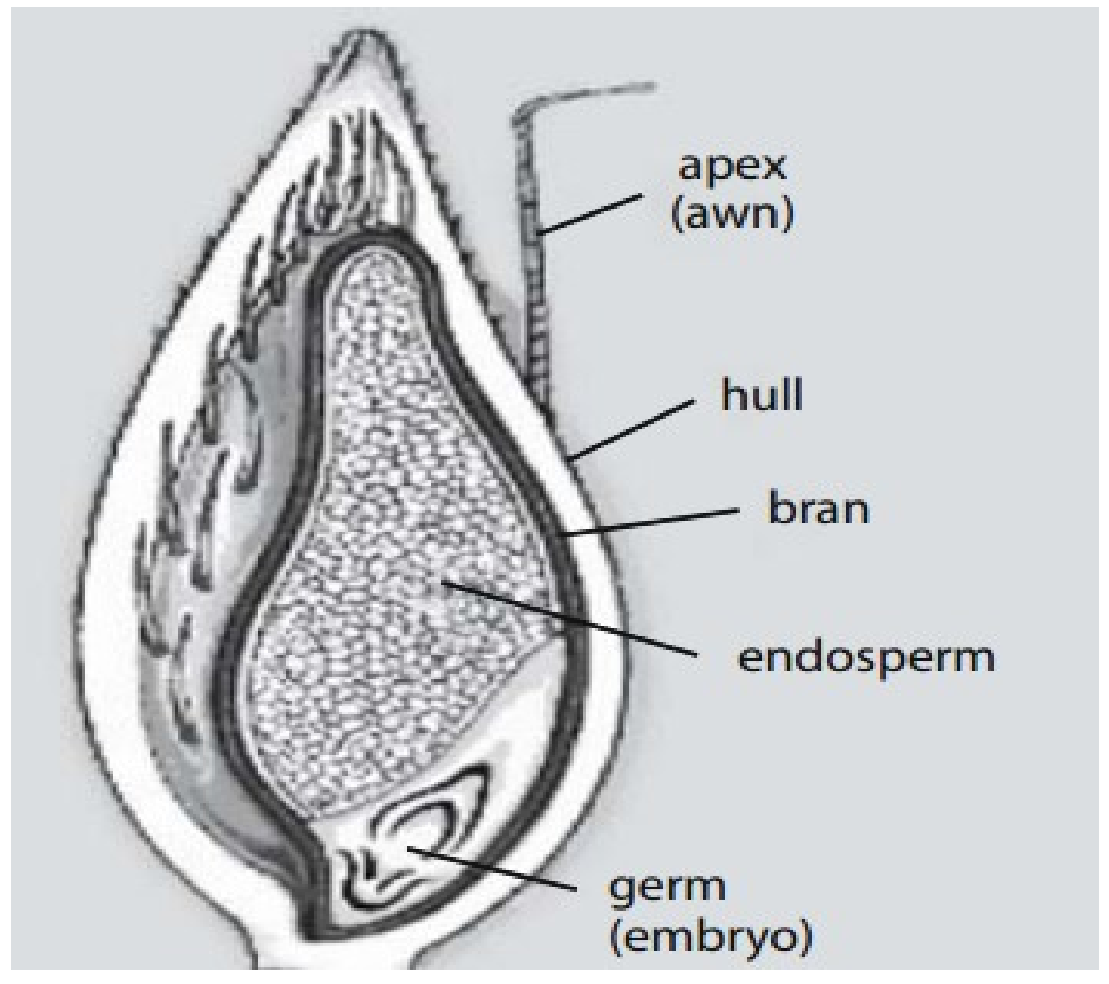

Figure 7: Cross-s ection of oat kernel (Butt et al., 2008)

\subsubsection{Oat Processing}

Unprocessed oat grains are not readily digestible, so they must be processed to convert them into a palatable and nutritious food through milling and other processing steps. Oat grain has lipid distributed throughout the seeds and also has a soft kernel, hence the difficulty in its milling process to separate the germ, endosperm and bran fractions compared to corn (maize) and wheat (McGrew \& Chambers, 2012).

The milling process involves the removal of foreign materials, isolate and stabilise the groats, thereby converting it into an easy to cook form. The milling process includes cleaning, dehulling and kilning, and then cutting, flaking or producing flour (Klose \& Arendt, 2012). Water is rarely used for this cleaning process because it promotes growth of microorganisms. The dehulling process is done until approximately $85 \%$ of the oat grains are dehulled and produces mixture of hulls, groats, unhulled oats and broken groats which are further separated. To prevent from atmospheric oxidation, the kilning process is done by giving a hydro-thermic treatment or live steaming to the oats, which also accelerates Maillard reaction, thereby producing desirable nutty flavours and 
caramelcolour, inactivates bacteria, yeasts and moulds that can decrease shelf-life and pose food safety risks (Decker, Rose, \& Stewart, 2014).

After the oat milling steps, the final products which includes the whole oat groats (Figure $8(1)$ ) and broken oat groats are further processed into oat flakes, steel-cut oats, oat flour, and oat bran. The whole oat groats are cut into smaller pieces (Figure 8 (2)) using instruments containing steel knives, followed by flattening or rolling the whole groats or the steel cut groats to produces oat flakes (Figure 8(3)), which are grounded using the mill to produce oat flour (Figure 8 (4)) mainly used for ready -to-eat cereals. Oat bran (Figure 8 (5)) is the coarse fraction of the oat flour separated by shifting the oat flour.
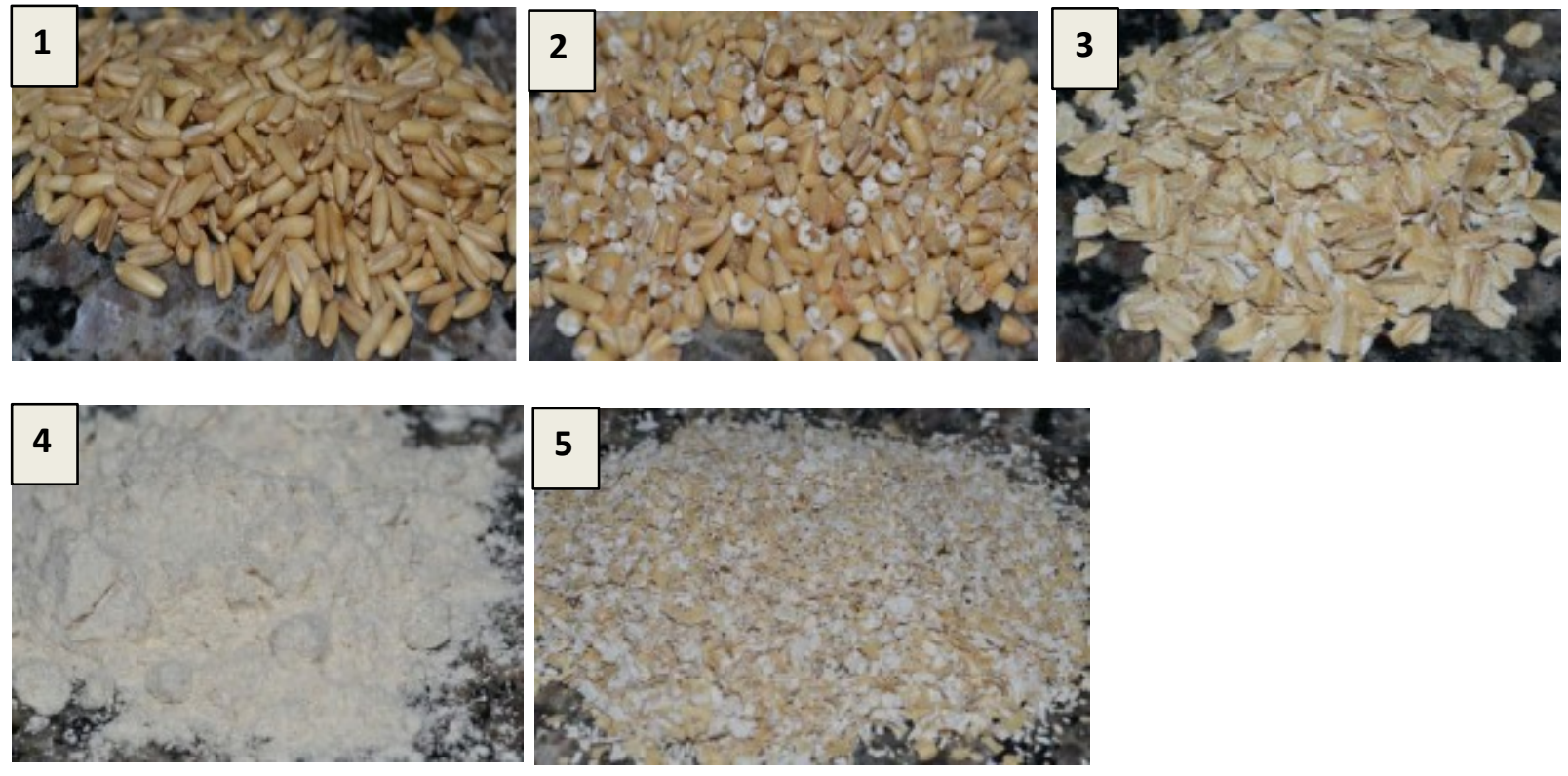

Figure 8: Different oat physical appearance as a result of processing (1) whole groats, (2) steel-cut groats, (3) oat flakes, (4) oat flour, and (5) oat bran (Decker et al., 2014)

\subsubsection{Oat Bran}

Oat bran is the edible, outermost layer of the oat kernel (Figure 7). It contains B complex vitamins, protein, fat, minerals, $\beta$-glucan and dietary fibre, mostly soluble fibre (Dimberg, Gissén, \& Nilsson, 2005). Oat bran comprises of $17.1 \%$ protein, $67.9 \%$ carbohydrates, $10.4 \% \beta$-glucan, $8.6 \%$ fat, $1.3 \mathrm{mg}$ 
niacin, $171 \mathrm{mg}$ magnesium, $15-22 \%$ dietary fibre, $6.4 \mathrm{mg}$ iron, $0.17 \mathrm{mg}$ copper, $441 \mathrm{mg}$ potassium and $\alpha-$ tocopherol less than $0.5 \mathrm{mg}$ per $100 \mathrm{~g}$ (Butt et al., 2008). Compared to oat flour, oat bran has relatively high protein content that ranges from $18-32 \mathrm{~g} / 100 \mathrm{~g}$ (Liu et. al., 2008). Protein extract from oat bran will increase the concentration of $\beta$-glucan or soluble fibre and in turn increase the value of oat byproduct (Dimberg et al., 2005). Low-calorie or low glycemic index food products increasingly use oat bran in their formulation because of the health benefits of $\beta$-glucan or oat fibre (Nnanna \& Gupta, 1996).

\subsection{Chemical composition of oat grains}

Whole oat kernel contains high levels of some nutrients valuable to human such as soluble fibres, proteins, carbohydrates, unsaturated fatty acids, vitamins, minerals, and phytochemicals (Table 6) (Kirk \& Sawyer, 1991). Recent studies have shown that oat contains many types of phytochemicals with antioxidant properties such as vitamin E, soluble fibres, phenols (e.g. avenanthramides), sterols, tocotrienols, phytic acids, flavonoids, phenolic acids, carotenoids, lignans, $\beta$-glucan, inulin and resistant starch. These molecules possess functions such as inhibition of pro-inflammatory cytokines and adhesion molecules, reduction of blood pressure, stress, tension, excitation and anxiety. There is also an improved endothelial function as indicated on studies on people with cardiovascular disorders and metabolic disease such as diabetes (Ahmed et al., 2013; Collins, Mclachlan, \& Blackwell, 1991; Dimberg et al., 2005). 
Table 6: Che mical composition of common oat, Avena sativa (Kirk \& Sawyer, 1991)

\begin{tabular}{|c|c|c|c|}
\hline Components & Average (\%) & Components & Average (\%) \\
\hline Moisture & 13.3 & Iron (mg/ 100g) & 3.8 \\
\hline Protein & 13 & Zinc (mg/ 100g) & 3.9 \\
\hline Lipids & 7.5 & Iodine (mg/ 100g) & 16 \\
\hline Fibre & 10.3 & Thiamine (mg/ 100g) & 0.50 \\
\hline Ash & 3.1 & Riboflavin (mg/ 100g) & 0.14 \\
\hline Calcium (mg/ 100g) & 60 & Niacin (mg/ 100g) & 1.3 \\
\hline Phosphorus (mg/ 100g) & 372 & Energy (mg/ 100g) & 1.61 \\
\hline
\end{tabular}

\subsubsection{Carbohydrates / Polysaccharides}

Carbohydrates are the main groups of nutrients in oat and make up about $90 \%$ of oat molecules. They are comprised of dietary fibres and starch. Oats fibres are known as $\beta$-glucans and consist of linear unbranched polysaccharide composed of 70\% 1-4-O-linked and 30\% 1-3-O-linked $\beta$-D-glucopyranosyl units (Figure 9); however, 1-3-linkages occur singly and most of the 1-4-linkages occur in groups of two or three (Wood, 1994). This mixed linkage (1-3)(1-4)- $\beta$-D-glucan ( $\beta$-glucan) makes it unique because it has high functional and nutritional properties exhibiting high viscosities at relatively low concentrations, hence its use in food industries as a thickening agent (Kent \& Evers, 1994). Foods rich in oat $\beta$-glucans are used to lower blood cholesterol and to control blood glucose of diabetic and prediabetic individuals (Singh et al., 2013). 


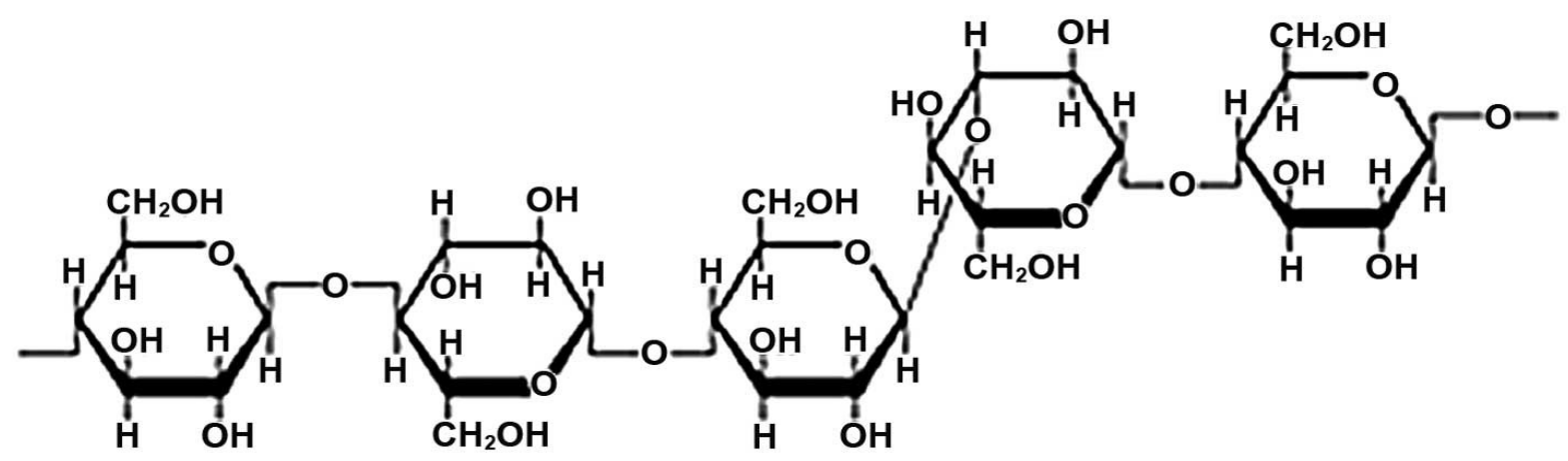

Figure 9: Structure of (1-3, 1-4)-ß-D-glucans (Daou \& Zhang, 2012)

\subsubsection{Oat Proteins}

Proteins are large biomolecules or macromolecules made of one or more long chains of amino acid residues linked together by peptide bonds. Peptides are protein molecules containing less than $20-$ 30 amino acid residues, while polypeptides are linear chain of amino acid residues. Therefore, proteins are described to have at least one long polypeptide chain which is typically made of 1002000 amino acids. Total proteins of oats are between $1520 \%$ by weight. Their quality is higher, due to better amino acid compositions compared to other cereal grains (Klose \& Arendt, 2012). Over $30 \%$ of oat protein is found in the embryo, followed by the bran which contains $20 \%$, endosperm containing about $10 \%$ and the hull containing more than $2 \%$ (Singh et al., 2013). Various procedures are reported in the literature for obtaining proteins from bran or whole oat flours.

\subsubsection{Methods of extracting proteins}

There are different methods used in the extraction of proteins which are based on the characteristics of proteins being extracted such as its size, subunit structure, solubility, heat-stability, metal binding capacity and amino acid compositions (KX Zhu, Zhou, \& Qian, 2006). These methods are to remove unwanted compounds such as lipids, nucleic acids, carbohydrates, and other non-protein substances that can interfere with proteins and therefore reduce extraction yields (Zayas, 1997). 
First the oat grain is milled into oat flour, defatted to remove fat in the oat, and then dried to be ready for protein extraction. Solubilisation is one of the methods used in protein extraction in food substances and it involves the use of organic solvents, aqueous solutions, aqueous enzymatic extraction, or subcritical water to extract protein (Zayas, 1997). However, the use of organic solvent has been found to denature protein leading to loss or reduced protein functionality. The most common method of protein extraction is the use of alkaline treatment; sample solution is being adjusted to certain $\mathrm{pH}$ using alkaline solutions, based on the precipitation of the protein in the sample (Jodayree et al., 2012). In order to enhance the extraction of protein in cereals, the cell wall polysaccharide attached to some proteins can be broken down by the use of enzymes. Carbohydrase such as Viscozyme L was used to enhance the extraction of protein in oat bran to $55.69 \%$ under a controlled enzyme concentration, incubation time, $\mathrm{pH}$ and incubation temperature in order to obtain a maximum protein yield, followed by the classification of the extracted proteins (J. Liu, Guan, Zhu, \& Sun, 2008).

\subsubsection{Classification of oat proteins}

There are 4 major groups of proteins in cereals including oats that differ based on their solubility in water, salt solution, alcoholic solution and alkaline buffer solution. They are albumins, globulins, prolamins, and glutelins (Figure 10).

Albumins are the water-soluble proteins fraction which is one of the minor storage proteins in oats, ranging between $1-12 \%$ of total protein. Glutelins accounts for about $10 \%$ of total oat proteins and are soluble in alkaline buffer solutions containing detergents and reducing agents (Mohamed, Biresaw, Xu, Hojilla-Evangelista, \& Rayas-Duarte, 2009). Prolamins (i.e. avenins) are the other minor storage proteins in oats, they are soluble in aqueous alcohol and have low estimates in oats ranging from about $4-15 \%$ of total proteins, however, prolamins are found to be major 
storage proteins and in higher amount in other cereals such as wheat (40-50\%), rye (30-50\%) and barley (35-45\%) total protein (Klose \& Arendt, 2012). Globulins (avenalins) are salt soluble major storage proteins in oats and are linked with higher nutritional value of oat proteins since they have more lysine compared to globulins from other cereals (Koehler \&Wieser, 2013). Globulins and prolamins are the dominant storage proteins in oat grains, with globulins accounting for about $80 \%$ and it is often identified with 3 different sedimentation coefficients such as $3 \mathrm{~S}, 7 \mathrm{~S}$ and $12 \mathrm{~S}$ globulins (Mohamed et al, 2009). One of the benefits of high-globulin, low-prolamin composition of oats protein is the balance in essential amino acids compared to other cereal protein (O. D. Anderson, 2014). According to WHO, oat proteins is almost the same as soy-protein which is equal to that of meat, milk, and egg protein (Singh et al., 2013).

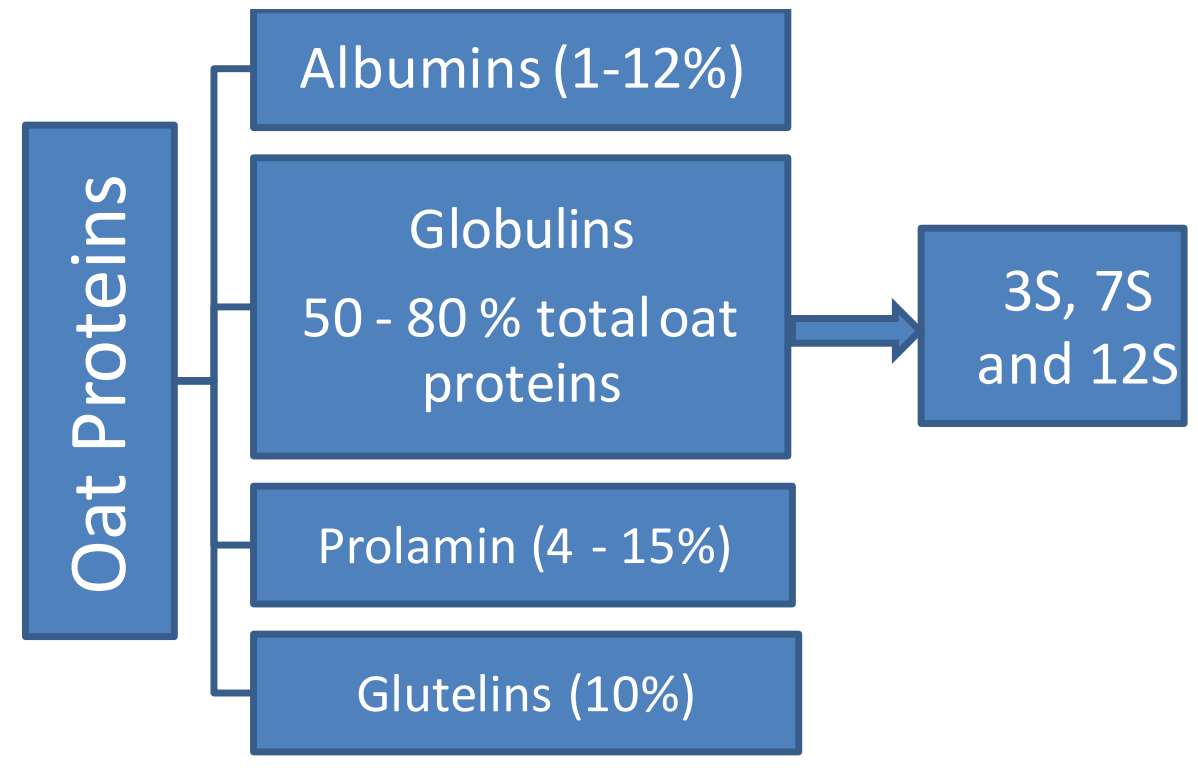

Figure 10: Classifications of oat proteins based on solubility

In the last decade, foods proteins have been investigated for their role beyond basic nutrition. To enhance their potential, extracted proteins are often fermented or treated with proteases of various specificities in attempts to release peptides with unique properties. Literature data then exist on biological activity of hydrolyzed proteins including those from oats. 


\subsection{Bioactivity of hydrolyzed proteins / peptides}

Hydrolyzed proteins (i.e. hydrolysates) contain amino acids and peptides usually with average molecular weights of $10 \mathrm{kDa}$ (Aluko, 2012). Short-chain peptides in hydrolyzed proteins have been found to have very high nutritive value and are efficiently utilized by the body. The biological activities of hydrolysates differ based on the type of protease used in the hydrolysis and their resulting amino acid sequence of released peptides. Protease such as trypsin, alcalase, papain, protamex, flavorzyme are reported to be effective in hydrolysing proteins in cereal as well as enhance the functionality of hydrolysates (Gao, Smith, \& Tsopmo, 2014; Kodama, Miyazaki, Kitamura, \& Suzuki, 2005; Li et al., 2010; Ma, 1985; Vanvi \& Tsopmo, 2016). Protein hydrolysates, because of their nutritive value. are being used in energy drinks, weight control products, sports nutrition products and in elderly nutrition products (Gao et al., 2014). Bioactive peptides or hydrolysates are able to reduce the risk of cardiovascular diseases, reduce blood sugar level, prevent tumor formation, reduce blood cholesterol level, scavenge oxidative compounds and reduce blood pressure (Aluko, 2012; Li et al., 2010). Protein hydrolysates and peptides with antioxidant activities can be produced from cereals such as wheat, barley, rice, rye, corn and oats. Food protein hydrolysates from soy, fish and quinoa has been evidently associated with antioxidant, antihypertensive, anticancer, hypocholesterolemic and antitumor properties (Udenigwe \& Aluko, 2012). Peptides from wheat germ exhibited mineral binding capacity by increasing the absorption of minerals in cell and animal model (Kodama et al, 2005). The antioxidant properties of hydrolysed milk protein was investigated and it was observed that milk-derived antioxidative peptides consist of 5-11 amino acids including hydrophobic amino acids, proline, histidine, tyrosine or tryptophan in the sequence (Pihlanto, 2006). Food protein hydrolysates could be used as natural antioxidants in enhancing antioxidant properties of functional foods and in preventing oxidation reaction in food processing (Korhonen \& Pihlanto, 2003; Pihlanto, 2006; Udenigwe \& Aluko, 2012) 


\section{Chapter 3 Methods and Materials}




\section{Methods and materials}

\subsection{Materials and reagents}

Medium oat bran flour (Product number 112-001) containing $16 \%$ total dietary fiber, 9.2\% moisture, 14 $\%$ Protein, and $5.5 \%$ beta-glucan was obtained from Richardson Milling (Portage la Prairie, MB, Canada). Viscozyme L(R) 100 Fungal Beta Glucanase (FBG)/g, cellulase 700 Endo-Glucanase Units $(\mathrm{EGU}) / \mathrm{g}$, flavourzyme 500 units/g, papain 1500 units $/ \mathrm{g}$, alcalase $2.4 \mathrm{units} / \mathrm{g}$, protamex $1.5 \mathrm{units} / \mathrm{g}$, pyrogallo1, Tris-HCL, 1,10- phenanthraline, glutathione (GSH), mono- and dibasic potassium phosphates and 6-hydroxy-2,5,7,8- tetramethylchroman-2-carboxylic acid (Trolox) were obtained from Sigma Aldrich (Oakville, ON, Canada). 2, 2'-Azobis (2-amidinopropane) dihydrochloride (AAPH) was obtained from Wako Chemical (Richmond, VA, USA). All SDS-PAGE reagents were obtained from Bio-Rad Laboratories Inc. (Mississauga, Ontario, Canada). Methanol, ethylacetate, hexanes, fluorescein, hydrogen peroxide and ferrous sulfate heptahydrate were purchased from Fisher Scientific Co. (Nepean, ON, Canada). High-purity water was produced in the laboratory by an Alpha-Q system (Millipore, Marlborough, MA). Spectrophotometric measurements were performed on the BioTek Epoch ${ }^{\mathrm{TM}} \mathrm{UV}-\mathrm{V}$ is microplate reader controlled by Gen5 ${ }^{\mathrm{TM}}$ data analysis software while incubations were done on a MaxQ ${ }^{\mathrm{TM}}$ 8000 incubator shaker model (Fisher Scientific, Nepean, ON) and New Brunswick incubator shaker, Model G25 (Edison, NJ,USA). Other materials and equipment used in this research includes pipettes and pipette tips, Refrigerator, freezer $\left(-80{ }^{\circ} \mathrm{C}\right)$, Polystyrene 96 -well $300 \mathrm{uL}$ flat-bottom plate, Stirring bars, Measuring cylinders, Glass pipettes, Volumetric flasks, Thermal sealing film (Fisher \# 361006020 or Sigma, Z369675)

\subsection{Defatting medium oat bran flour}

Medium oat bran flour samples, $100 \mathrm{~g}$ each were defatted using $300 \mathrm{~mL}$ hexane $(1: 3 \mathrm{w} / \mathrm{v})$. Each sample batch was stirred for 1 hour at room temperature in a fume hood using a $10 \times 10$ inches magnetic stirrer 
plate (VWR International, Mont-Royal, Quebec). Hexane containing the fat was filtered using cheese cloth and the defatted oat brans were left to dry overnight under the fume hood.

\subsection{Extraction of proteins}

Defatted medium oat bran samples were mixed with $500 \mathrm{~mL}$ of deionized water 1:10 (w/v) ratios and blended to obtain homogeneous slurries. The $\mathrm{pH}$ of slurries were adjusted to $4.5 \mathrm{using} 1 \mathrm{M} \mathrm{HCL}$ and then treated with viscozyme or cellulase which are carbohydrases proven to hydrolyze cell wall components in order to improve protein extraction (Rosset, Acquaro, \& Beléia, 2014). Viscozyme and cellulase were added at a ratio of $3 \mathrm{FBG} / \mathrm{g}$ and $20 \mathrm{EGU} / \mathrm{g}$, respectively of defatted bran followed by $1 \mathrm{~h} 30 \mathrm{~min}$ incubation at $45{ }^{\circ} \mathrm{C}, 150 \mathrm{rpm}$ on a MaxQ ${ }^{\mathrm{TM}} 8000$ incubator shaker. At the end of the incubation, the $\mathrm{pH}$ of the slurries were adjusted to 9.5 with $1 \mathrm{M} \mathrm{NaOH}$ solution and further incubated for $30 \mathrm{~min}$. Samples were cooled down and centrifuged at $2500 \mathrm{xg}$, for $20 \mathrm{~min}, 4{ }^{0} \mathrm{C}$. To obtain protein isolates, the $\mathrm{pH}$ of each supernatant was adjusted to 4.0 and centrifuged at $10,000 \mathrm{xg}$ for $40 \mathrm{~min}$ at $4{ }^{0} \mathrm{C}$. The protein isolates (pellet) were collected, washed with water ( $\mathrm{pH} \mathrm{4.0)}$ and centrifuged for $15 \mathrm{~min}$ at 1100xg. Oat bran protein isolates (OBPIs) were finally dissolved in pure water, adjusted $\mathrm{pH}$ to 7.0 and freeze dried and stored at $-20{ }^{0} \mathrm{C}$ freezer until further analyses.

\subsection{Hydrolysis of proteins}

Viscozyme and Cellulase extracted protein isolates were digested with alcalase, papain and pepsin, and flavourzyme. $500 \mathrm{mg}$ each of oat bran protein isolates were suspended in water 1:20 ratio. The $\mathrm{pH}$ of each sample was adjusted to the optimum value of each protease as shown in Table 7. Digestions were performed at specific times, temperatures, rpm and enzyme/substrate $(\mathrm{E} / \mathrm{S})$ displayed in Table 7. At the end of hydrolysis, each protease was inactivated at $90{ }^{0} \mathrm{C}$ for $10 \mathrm{~min}$, and then allowed to cool in a $4{ }^{0} \mathrm{C}$ refrigerator. The resulting Oat Bran Protein Hydrolysate (OBPH) samples were centrifuged at 8000xg for 
$15 \mathrm{~min}$ to remove enzymes and non-digested proteins. Supernatants (protein hydrolysates) were collected, freeze dried and stored in $-20{ }^{0} \mathrm{C}$ freezer until further analyses.

Table 7: Hydrolysis of proteins extracted by Viscozyme and Cellulase

\begin{tabular}{|c|c|c|c|c|c|}
\hline $\begin{array}{c}\text { Protease } \\
\text { (Product } \\
\text { number - } \\
\text { Sigma) }\end{array}$ & Amount & $\begin{array}{c}\text { Optimum } \\
\text { pH }\end{array}$ & $\begin{array}{c}\text { Incubation } \\
\text { Time and } \\
\text { Temp }\end{array}$ & $\begin{array}{c}\text { Inactivation } \\
\text { Time and } \\
\text { Temp }\end{array}$ & Centrifuge \\
\hline $\begin{array}{c}\text { Flavourzyme } \\
\text { (P6110) }\end{array}$ & $\begin{array}{c}4 \% \mathrm{w} / \mathrm{w} \text { for } \\
500 \mathrm{U} / \mathrm{g} \\
18.2 \mu \mathrm{L} / 0.5 \\
\mathrm{~g} \text { of protein } \\
\text { isolate }\end{array}$ & 7 & $\begin{array}{c}50{ }^{0} \mathrm{C} \text { for } 5 \\
\text { hours }\end{array}$ & $\begin{array}{c}90{ }^{0} \mathrm{C} \text { for } 10 \\
\text { minutes }\end{array}$ & $\begin{array}{l}8000 x g \text { for } \\
15 \text { minutes }\end{array}$ \\
\hline $\begin{array}{l}\text { Papain } \\
\text { (P3375) }\end{array}$ & $\begin{array}{c}3 \% \mathrm{w} / \mathrm{w} \text { for } \\
1500 \mathrm{U} / \mathrm{g} \\
15 \mathrm{mg} \text { of } \\
\text { protease / } 0.5 \\
\text { g of sample }\end{array}$ & 7 & $\begin{array}{c}60{ }^{0} \mathrm{C} \text { for } 4 \\
\text { hours }\end{array}$ & $\begin{array}{c}90{ }^{0} \mathrm{C} \text { for } 10 \\
\text { minutes }\end{array}$ & $\begin{array}{l}8000 x g \\
\text { for } 15 \\
\text { minutes }\end{array}$ \\
\hline Alcalase & $\begin{array}{c}3 \% \mathrm{w} / \mathrm{w} \text { for } \\
1500 \mathrm{U} / \mathrm{g} \\
15 \mathrm{mg} \text { of } \\
\text { protease / } 0.5 \\
\mathrm{~g} \text { of sample }\end{array}$ & 8 & $\begin{array}{c}60{ }^{0} \mathrm{C} \text { for } 4 \\
\text { hours }\end{array}$ & $\begin{array}{c}90{ }^{0} \mathrm{C} \text { for } 10 \\
\text { minutes }\end{array}$ & $\begin{array}{l}8000 \mathrm{xg} \\
\text { for } 15 \\
\text { minutes }\end{array}$ \\
\hline Protamex & $\begin{array}{c}3 \% \mathrm{w} / \mathrm{w} \text { for } \\
1500 \mathrm{U} / \mathrm{g} \\
15 \mathrm{mg} \text { of } \\
\text { protease / } 0.5 \\
\mathrm{~g} \text { of sample }\end{array}$ & 7 & $\begin{array}{c}60{ }^{0} \mathrm{C} \text { for } \\
\text { 4hours }\end{array}$ & $\begin{array}{l}90{ }^{0} \mathrm{C} \text { for } \\
10 \text { minutes }\end{array}$ & $\begin{array}{l}8000 \mathrm{xg} \\
\text { for } 15 \\
\text { minutes }\end{array}$ \\
\hline
\end{tabular}

\subsection{Determination of protein contents}

Amounts of proteins in OBPIs and OBPHs were determined with a UV-Vis spectrophotometer at $660 \mathrm{~nm}$ based on the modified Lowry method (Markwell, Haas, Bieber, \& Tolbert, 1978). Bovine serum albumin Standard (BSA: Sigma Aldrich, Oakville, ON, Canada) which was used as the reference protein in the 
assay was prepared by dissolving $10 \mathrm{mg}$ of stock BSA in $10 \mathrm{~mL}$ of water. Stock BSA was diluted to make concentrations of $0,10,20,40,60,80$, and $100 \mu \mathrm{g} / \mathrm{mL}$. Stock solutions of reagents $\mathrm{A}, \mathrm{B}$ and $\mathrm{C}$ were prepared as follows; reagent $\mathrm{A}$ contains $2.0 \% \mathrm{Na}_{2} \mathrm{CO}_{3}, 0.4 \% \mathrm{NaOH}, 0.16 \%$ sodium tartrate and $1 \%$ SDS; reagent B contains $4 \% \mathrm{CuSO} 4$; and reagent C (prepared on the day of use) contains 100parts of reagent $\mathrm{B}+1$ part of reagent $\mathrm{A}$.

$1 \mathrm{~mL}$ each of 80 and $120 \mu \mathrm{g} / \mathrm{mL}$ of OBPIs and OBPHs samples solutions were prepared in quadruplicates. $600 \mu \mathrm{L}$ of reagent $\mathrm{C}$ was added to $200 \mu \mathrm{L}$ each of samples (vortex mix immediately after addition) and incubated at room temperature for 25 mins. $60 \mu \mathrm{L}$ of diluted Folin-Ciocalteu phenol reagent (1:1 dilution with pure water) was added to all sample mix (vortex mix directly after addition to avoid color localization) and incubated at room temperature for $45 \mathrm{~min}$. The absorbance was read at $660 \mathrm{~nm}$ on the Epoch Biotech microplate reader and the system was blanked with $0 \mu \mathrm{g} / \mathrm{mL}$ BSA.

\subsection{Sodium Dodecyl Sulfate-Polyacrylamide Gel Electrophoresis (SDS- PAGE)}

SDS-PAGE was performed with the modification of the well-established method (Laemmli, 1970) as described by (Guan, Yao, Chen, Shan, \& Zhang, 2006). The composition of proteins in isolates and hydrolysates were analyzed on SDS-PAGE slab gels which consisted of $12 \%$ separating gel (pH 8.6) and $5 \%$ stacking gel (pH6.8). OBPI and OBPH samples were dissolved in sample buffer consisting of 125 $\mathrm{mM}$ Tris- $\mathrm{HCl}(\mathrm{pH} 6.8), 1 \%$ (w/v) SDS, $5 \%$ (v/v) glycerol, $2 \%$ (v/v) 2-mecapoethanol (2-ME), and 0.02 $\%(\mathrm{v} / \mathrm{v})$ agarose gel loading dye. Ten microliters of the OBPI and OBPH samples as well as the molecular biomarker were loaded in each lane of the gel for electrophoresis. After electrophoresis, the gels were stained in Coomassie Brilliant Blue R-250 and destained in solution containing $10 \%$ Acetic acid and 20\% Methanol. Gel slabs containing each protein bands were compared to a standard mixture to determine relative molecular weights. 


\subsection{Characterization of protein isolates and hydrolysates}

The amino acid composition of the protein isolates and hydrolysates samples was determined using the following assays;

\subsubsection{Intrinsic Absorbance of Protein and Hydrolysates}

The absorbance of OBPI and OBPH samples was determined according to a previously reported method by (Bhattacharya, Jain, Bhasne, Kumari, \& Mukhopadhyay, 2011). Phenylalanine, tyrosine and tryptophan are the 3 aromatic amino acids with intrinsic UV absorbance properties but tryptophan gives the strongest absorbance coefficient signals at wavelength $280 \mathrm{~nm}$. Samples were dissolved in $0.1 \mathrm{M}$ phosphate buffer to give a final concentration of 0.5 and $1 \mathrm{mg} / \mathrm{mL} .200 \mu \mathrm{L}$ of the samples were transferred into a clear microplate and $200 \mu \mathrm{L}$ of reaction buffer was the blank. Absorbance of the samples was recorded at $280 \mathrm{~nm}$ wavelength on BioTeK Epoch microplate reader.

\subsubsection{Sulfhydryl (-SH) Assay}

Free and total sulfhydryl (-SH) were measured in OBPI and OBPH samples using Ellman's method. Ellman's method is based on the colorimetric reaction between 5,5'-dithio-bis-(2-nitrobenzoic acid) also known as DTNB and free (reduced) sulfhydryl group to produce a yellow colored compound called 2nitro-5-thiobenzoic acid (TNB) which is detected at a wavelength of $412 \mathrm{~nm}$ (Sedlak \& Lindsay, 1968). Samples were dissolved in $0.1 \mathrm{M}$ potassium phosphate buffer, $\mathrm{pH} 8.0$ containing $1 \mathrm{mM}$ EDTA. Cysteine standards were prepared at concentration $0-1.5 \mathrm{mM}$. The sulfhydryl groups in the isolates and hydrolysates were characterized by comparing the data to the cysteine standards according to literature report (Ellman, 1959).

\subsection{In vitro antioxidant activities of OBPIs and OBPHs}

Antioxidant properties of the OBPI and OBPH samples were analysed using the following radical scavenging assays; Oxygen radical absorbance capacity (ORAC), hydroxyl radical $\left(\mathrm{HO}^{\bullet}\right)$ and Superoxide 
anion radicals $\left(\mathrm{O}_{2}^{-\bullet}\right)$; and lipid peroxidation $\left(\mathrm{LOO}^{\bullet}\right)$. These three radical scavenging assays were used because they have been reported to be the most efficient and provides different results when characterizing the antioxidant capacity of proteins and food-derived peptides (Chakrabarti, Jahandideh, \& Wu, 2014; Khang, Vasiljevic, \& Xuan, 2016; TPA et al., 2004)

\subsubsection{Determination of Oxygen Radical Absorbance Capacity (ORAC)}

ORAC assay was performed with some modifications according to well-established method by (Huang, Ou, Hampsch-Woodill, Flanagan, \& Prior, 2002). In summary, ORAC buffer working solution (75 mM phosphate buffer, $\mathrm{pH} 7.4$ ) was prepared and stored at room temperature. $25 \mathrm{~mL}$ of $8.37 \times 10^{-4} \mathrm{M}$

Fluorescein Concentrated Solution was prepared and stored in $-80{ }^{\circ} \mathrm{C}$ (stable for up to1 year). Fluorescein stock solution $(4.19 \mu \mathrm{M})$ was made by diluting $100 \mu \mathrm{L}$ of FL concentrate in $20 \mathrm{~mL}$ of $75 \mathrm{mM}$ phosphate buffer (pH 7.4) and stored wrapped in aluminum foil at $5{ }^{\circ} \mathrm{C}$ (stable for a month). Immediately prior to use, Fluorescein working solution $\left(8.16 \times 10^{-2} \mathrm{M}\right)$ was prepared by adding $975 \mu \mathrm{L}$ of FL stock to $50 \mathrm{~mL}$ of $75 \mathrm{mM}$ phosphate buffer (pH 7.4). The FL working solution is prepared daily and stored in the dark by wrapping in aluminum foil. AAPH $(0.3911 \mathrm{~g})$ was dissolved in $10 \mathrm{ml}$ of $75 \mathrm{mM}$ phosphate buffer (pH 7.4) to a final concentration of $140 \mathrm{mM}$. AAPH solution is used immediately or placed on ice bath up to 8 hours and made fresh daily. Trolox standard was prepared as follows: $0.0129 \mathrm{~g}$ of Trolox was dissolved in $50 \mathrm{~mL}$ of $75 \mathrm{mM}$ phosphate buffer (pH 7.4) to give a $1000 \mu \mathrm{M}$ stock solution. The stock solution was diluted with $75 \mathrm{mM}$ phosphate buffer to $100 \mu \mathrm{M}$ which is further diluted using the same buffer to 50, 25, 12.5, and $6.25 \mu \mathrm{M}$ working solutions. $1 \mathrm{mg} / \mathrm{mL}$ aliquots of Glutathione (GSH) were used as control, prepared and stored in $-80{ }^{\circ} \mathrm{C}$ freezer. $5 \mathrm{mg} / \mathrm{mL}$ of OBPI and OBPH samples were prepared in $75 \mathrm{mM}$ phosphate buffer ( $\mathrm{pH} 7.4$ ) and further diluted to give $1,0.2$ and $0.1 \mathrm{mg} / \mathrm{mL}$.

The samples and reagent were added to the 96-well dark microplate. The exterior wells were not used for experimental analysis; they were filled with $200 \mu \mathrm{L}$ water while the interior wells were used in the analysis. Each experimental well was filled with $120 \mu \mathrm{L}$ of FL working solution. $20 \mu \mathrm{L}$ of ORAC buffer 
was pipetted in the Blank wells; $20 \mu \mathrm{L}$ of Trolox dilutions were pipetted in the standard wells, $20 \mu \mathrm{L}$ of samples and $20 \mu \mathrm{L}$ of control were pipetted in the respective wells. The plate was covered and allowed to incubate in the dark for 20 minutes in the Biotek FL800x Microplate Reader preheated at $37{ }^{0} \mathrm{C}$ with 3 minutes shaking during this time. After 20 minutes incubation, the reaction was initiated by pipetting $60 \mu \mathrm{L}$ of AAPH $(140 \mathrm{mM})$ into all well containing blanks, standards, samples and control. The fluorescence was then monitored kinetically with data collected every 60 seconds for 35 minutes. The Biotek FL800x Microplate Reader was used with a $485 \mathrm{~nm} / 20 \mathrm{~nm}$ bandpass, excitation filter and a $528 \mathrm{~nm} / 20 \mathrm{~nm}$ bandpass, emission filter.

ORAC values were calculated as described by (Cao \& Prior, 1999). The area Under Curve (AUC) and the Net AUC of the standards and samples were determined using KC4 ${ }^{\mathrm{TM}}$ Software on the BioTek Instrument using equations 10,11 and 12 respectively.

$$
\mathrm{AUC}=0.5+(\mathrm{F} 2 / \mathrm{F} 1)+(\mathrm{F} 3 / \mathrm{F} 1)+(\mathrm{F} 4 / \mathrm{F} 1)+\ldots+0.5(\mathrm{Fn} / \mathrm{F} 1) \quad \text { Equation } 10
$$

Where F1 is the fluorescence reading at the initiation of the reaction and Fn is the last fluorescence measurement.

$$
\begin{array}{lr}
\text { Net AUCsample }=\text { AUCsample }- \text { AUCblank } & \text { Equation } 11 \\
\text { Net AUCtrolox }=\text { AUCtrolox }- \text { AUCblank } & \text { Equation } 12
\end{array}
$$

The standard curve was obtained by plotting the Net AUC of different Trolox® concentrations against their individual concentration. ORAC values of samples were then calculated automatically using the $\mathrm{KC}^{\mathrm{TM}}$ software to plot the sample's Net AUC values against the Trolox ${ }^{\circledR}$ standard curve.

\subsubsection{Hydroxyl Radical $\left(\mathrm{HO}^{\circ}\right)$ scavenging assay}

Hydroxyl radical $\left(\mathrm{HO}^{\bullet}\right)$ scavenging assay was performed according to the reported method by (Alrahmany \& Tsopmo, 2012a) with some modifications in order to determine if the protein isolates and hydrolysates can chelate ferrous ions and prevent/reduce the formation of $\mathrm{HO}^{\bullet}$. Briefly, $0.5 \mathrm{mg} / \mathrm{mL} \& 1$ 
$\mathrm{mg} / \mathrm{mL}$ OBPI and OBPH samples and glutathione (positive control) were prepared in $0.75 \mathrm{mM}$ potassium phosphate buffer at $\mathrm{pH} 7.4$. In 96-well clear microplate, $50 \mu \mathrm{L}$ of samples and positive control was added in triplicates with $0.75 \mathrm{mM}$ potassium phosphate buffer as blank sample followed by the addition of $50 \mu \mathrm{L}$ of $3 \mathrm{mM} \mathrm{1,10-phenanthroline} \mathrm{prepared} \mathrm{in} \mathrm{phosphate} \mathrm{buffer} \mathrm{and} 50 \mu \mathrm{L}$ of $3 \mathrm{mM} \mathrm{FeSO} \cdot 7 \mathrm{H}_{2} \mathrm{O}$ to all samples, control and blank. $50 \mu \mathrm{L}$ of $0.03 \%$ aqueous $\mathrm{H}_{2} \mathrm{O}_{2}$ was added to samples and control to initiate the reaction, while $50 \mu \mathrm{L}$ of water was added to blank and the plate was sealed and incubated at $37{ }^{0} \mathrm{C}$ for $1 \mathrm{~h}$ with shaking at $120 \mathrm{rpm}$. The absorbance was measured at $536 \mathrm{~nm}$ on the microplate reader. $\mathrm{HO}^{\bullet}$ scavenging activity was calculated in percentage using the following formula:

$$
(\mathrm{As}-\mathrm{Ac}) /(\mathrm{A} 0-\mathrm{Ac})] \times 100 \quad \text { Equation } 13
$$

Where As: absorbance of the sample; Ac: absorbance of the control solution containing 1,10phenanthroline, $\mathrm{FeSO}_{4}$ and $\mathrm{H}_{2} \mathrm{O}_{2} ; \mathrm{A} 0$ : absorbance of the blank solution containing 1,10-phenanthroline and $\mathrm{FeSO} 4$

\subsubsection{Superoxide radical $\left(\mathrm{O}_{2}^{-\bullet}\right)$ scavenging activity}

Superoxide scavenging activity of the OBPI and OBPH samples and glutathione (positive control) was measured as previously reported by (Alrahmany \& Tsopmo, 2012a) with slight modifications. Samples and GSH were dissolved in $50 \mathrm{mM}$ Tris-HCL buffer containing $1 \mathrm{mM}$ EDTA, pH 8.3 to a final concentration of $1 \mathrm{mg} / \mathrm{mL}$. To run the assay $80 \mu \mathrm{L}$ of each OBPI and OBPH sample or GSH control was mixed with $80 \mu \mathrm{L}$ of the buffer in a 96 -well clear round bottom microplate in darkness. $160 \mu \mathrm{L}$ of $50 \mathrm{mM}$ Tris-HCL buffer was used as a negative control. Then, $70 \mu \mathrm{L}$ of $2.0 \mathrm{mM}$ pyrogallol dissolved in $10 \mathrm{mM}$ HCL was added to each well except the blank in which $70 \mu \mathrm{L}$ of $10 \mathrm{mM}$ HCL was added. The reaction rate $(\Delta \mathrm{A} / \mathrm{min})$ was measured immediately at $420 \mathrm{~nm}$ for 4 minutes at room temperature on BioTeK Epoch microplate reader (Fisher Scientific, Nepean, ON). The superoxide scavenging activity was calculated using the following equation; 
Superoxide scavenging activity $(\%)=\{[(\Delta \mathrm{A} / \mathrm{min}) \mathrm{c}-(\Delta \mathrm{A} / \mathrm{min}) \mathrm{s}] /(\Delta \mathrm{A} / \mathrm{min}) \mathrm{c}\} \quad \mathrm{x} 100$ Equation 14

Where; $(\Delta \mathrm{A} / \mathrm{min}) \mathrm{c}=$ reaction rate of control, $(\Delta \mathrm{A} / \mathrm{min}) \mathrm{s}=$ reaction rate of sample

\subsubsection{Lipid Peroxidation Assay}

Hydrogen peroxides in meat (chicken breast) samples were analyzed by the modification of a previously reported ferrous oxide xylenol (FOX) orange assay (Nourooz-Zadeh, 1998). Briefly, FOX reagent was prepared by adding one part volume of solution A (which contains the mixture of $2.5 \mathrm{mM}$ ferrous ammonium sulphate and $1.0 \mathrm{mM}$ xylenol orange dissolved in $250 \mathrm{mM} \mathrm{H}_{2} \mathrm{SO}_{4}$ ) to nine part volume of solution $\mathrm{B}$ (which contains $53.87 \mathrm{mg}$ of $\beta$-Hydroxytoluene (BHT) dissolved in $50 \mathrm{~mL}$ of methanol). The calibration standard solutions are prepared from a stock solution of $30 \% \mathrm{H}_{2} \mathrm{O}_{2}$ with a $10 \mathrm{M}$ concentration and diluted into eight working standard concentrations $(5-200 \mu \mathrm{M})$. Lipids were extracted from the chicken breast that was treated with OBPI and OBPH samples using chloroform methanol (2:1). FOX reagent was mixed with lipid samples and standard solutions in the ratio $1140 \mu \mathrm{L}$ : $60 \mu \mathrm{L}$, followed by the incubation of all samples and standards for $30 \mathrm{~min}$ at room temperature and were read at an absorbance of $560 \mathrm{~nm}$. The lipid peroxide concentrations were calculated using the calibration curve and expressed as micro-moles of $\mathrm{H}_{2} \mathrm{O}_{2}$ per gram of wet weight. OBPI and OBPH treated samples, as well as the untreated samples (control) were analyzed right away at Room Temperature (RT $=22-$ $23^{0} \mathrm{C}$ ) while other batches were analyzed after 24 hours storage at $4{ }^{0} \mathrm{C}$ and $-20{ }^{0} \mathrm{C}$.

\subsection{Processing of meat samples for analyzing arsenic and chromium species}

The effect of OBPI and OBPH samples on arsenic and chromium species was determined in meat samples. First, $5 \mathrm{~g}$ meat samples and $5 \mathrm{mg}$ OBPI or OBPH were homogenized to give a smooth paste-like sample. Then the homogenized samples were divided into 3 aliquots, 2 of which were stored separately at 4 degrees and -20 degrees for 24 hours before analysis. Enzyme (50 mg papain) in $5 \mathrm{ml}$ of $50 \mathrm{mM}$ ammonium bicarbonate $\left(\mathrm{NH}_{4} \mathrm{HCO}_{3}\right)$ were added to $0.5 \mathrm{~g}$ each of the samples and thoroughly mixed using 
a vortex. They were incubated in water bath for 1 hour at 63 degrees, followed by 10 minutes sonication at amplitude of 50 . The samples were then centrifuges at $4000 \mathrm{rpm}$ for 20 minutes and then filtered through $0.45 \mu \mathrm{m}$ syringe filters into auto sampler vials for HPLC-ICP-MS analysis. Calibration standards were produced daily using 1ppb As (III) and As (V) spikes made form 1000 ppm Arsenic 3 and 5 stock standards; and 1ppb Cr (III) and Cr (VI) spikes made form 1000ppm chromium 3 and 6 stock standards. Arsenic and chromium speciation was analyzed instead of total arsenic or total chromium in order to quantify the effects of OBPI or OBPH on the distribution of these metal species. $0.1 \mathrm{M}$ EDTA and $1 \mathrm{mM}$ EDTA were used as preservative to stabilize arsenic and chromium species respectively. Concentration of arsenic and chromium were calculated using the calibration standards and expressed in part per billion (ppb) or Nano gram arsenic/chromium per milliliter of sample extract (ng/mL).

\subsection{Analysis of arsenic and chromium species by HPLC-ICP-MS}

The determination of chromium and arsenic species using HPLC-ICP-MS was based on previously described method (Day, Montes-Bayón, \& Vonderheide, 2002; Hulle, Zhang, Zhang, \& Cornelis, 2002). An Agilent 7500cx octopole reaction system (ORS) ICP-MS, and an Agilent 1200 series liquid chromatograph, equipped with an auto sampler and column temperature control was connected. Chromatographic separation was achieved through ion pair separation using a Phenomenex reversed phase ODS-3 column $(150 \times 4.6 \mathrm{~mm}, 3 \mu \mathrm{m}$ particle size $)$. The mobile phase contained $5 \mathrm{mmol} / \mathrm{L}$ TBA, $5 \%$ methanol, and $3 \mathrm{mmol} / \mathrm{L}$ malonic acid, with a flow rate of $1.2 \mathrm{~mL} / \mathrm{min}$. Arsenite (As (III)) and arsenate (As (V)) were separated in approximately $6 \mathrm{~min}$ as well as trivalent ( $\mathrm{Cr}$ (III)) and hexavalent chromium (Cr (VI)) as shown in Figure 11 and 12. The individual arsenic and chromium species were detected at m/z 75 and 52 respectively with an Agilent 7500cx HPLC-ICP-MS. 


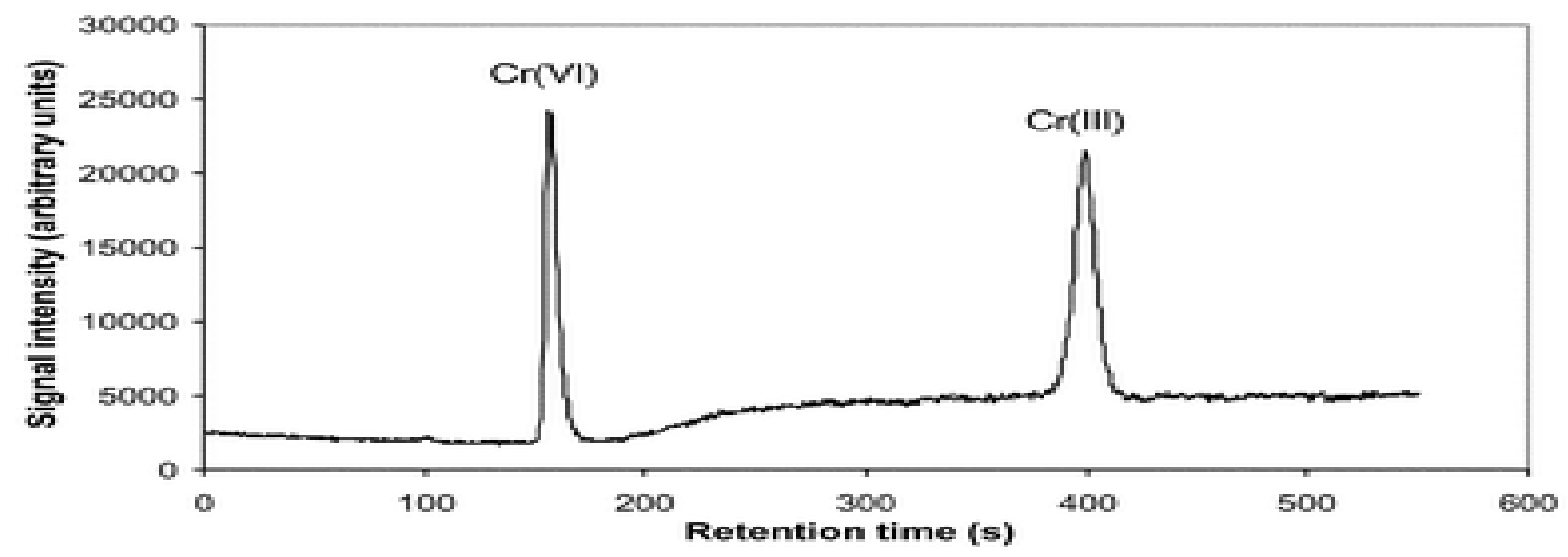

Figure 11 : HPLC/ICP/MS chromatograms of chromium speciation in me at samples spiked with Cr (VI) and $\mathrm{Cr}$ (III) after 6 minutes

Full Time Range EIC(75) : 14081345.D

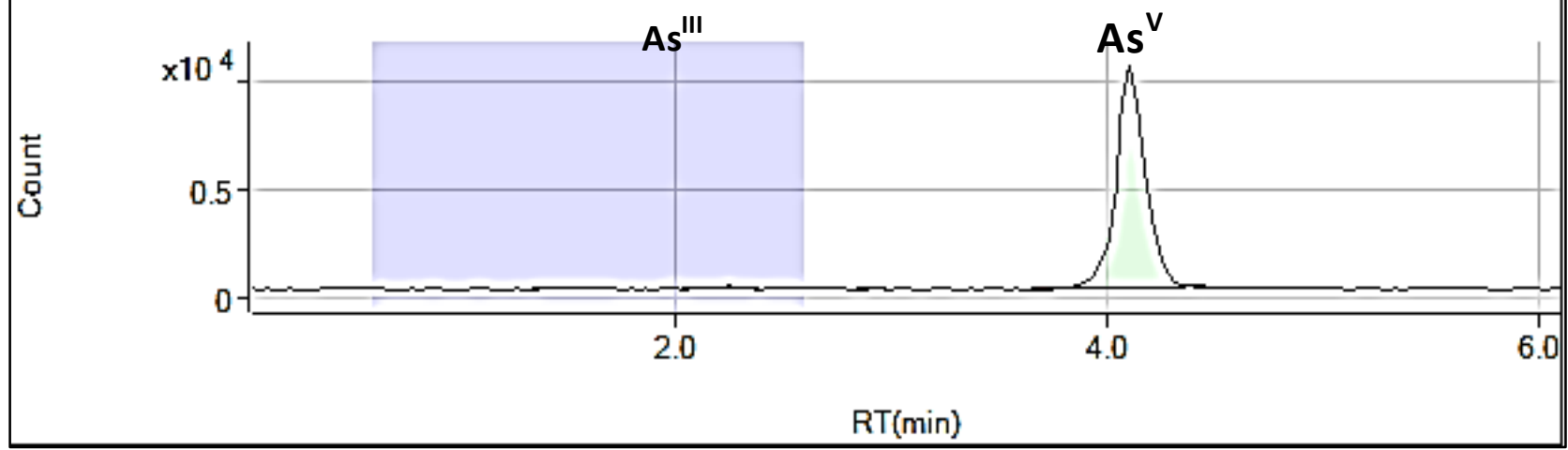

Figure 12 : HPLC/ICP/MS chromatograms of ars enic speciation in me at samples spiked with As (III) and As (V) after 6 minutes

\subsection{Statistical analysis}

Data are shown as mean \pm standard deviation. Statistical differences were evaluated by a one-way analysis of variance (ANOVA) using SPSS 11.0 for Windows 7 (SPSS Inc., Chicago). Fisher's least significant difference was used to determine the significant difference between groups $(\mathrm{p}<0.05)$. A simple linear regression was performed using Microsoft Excel 2010 (Microsoft, Redmond, WA, USA). 


\section{Chapter 4 Results and Discussion}




\section{RESULTS AND DISCUSSION}

Medium oat bran samples were defatted and pre-treated with carbohydrases viscozyme, or cellulase. This process has been reported to break down cell wall polysaccharides, to reduce viscosity of slurries and hence increased extraction yields (Sowbhagya, Srinivas, \& Krishnamurthy, 2010; Sowbhagya, Srinivas, \& Purnima, 2011; Tang \& Hettiarachchy, 2003). Following extractions, oat bran protein isolates (OBPI) from Viscozyme or cellulase treated samples were hydrolyzed with four proteases to obtain a total of eight hydrolysates. These enzymes were selected because they are commonly used for in vitro digestion of food proteins and have been reported to show high protease activities in several studies done on cereal (Claver \& Zhou, 2005; Hou, Li, Zhao, Zhang, \& Li, 2011; Kim, Lee, Lim, Jeon, \& Song, 2008). Alcalase is an alkaline serine protease with broad substrate specificity and most active at $\mathrm{pH}$ 7-9. It has been shown to have high specificity for aromatic, acidic, hydroxyl, basic and sulphur containing amino acid residues (Doucet, Otter, Gauthier, \& Foegeding, 2003). Papain is a cysteine or thiol protease with broad specificity and active at pH 5-7. Flavourzyme is an enzyme with exo and endo-peptidase activity due to its complex composition of peptides, hence its extensive specificity at optimum pH 7 (Merz et al., 2015). Protamex is an endopeptidase with broad specificity for hydrophobic amino acids such as tryptophan, methionine, and phenylalanine etc.

Alcalase, papain, flavourzyme, and protamex hydrolysates from viscozyme treated brans were indexed VAL, VPA, VFL and VPRO, respectively while those from cellulase treated brans were named CAL, CPA, CFL and CPRO.

Protein isolates $(\mathrm{OBPI})$ and their hydrolysates $(\mathrm{OBPH})$ were characterized based on protein contents and relative molecular weights. In addition their antioxidant activities and potential to reduce naturally occurring toxic metal contaminants such as As and $\mathrm{Cr}$ to non-toxic forms were determined. 
Data that are statistically similar $(\mathrm{p}<0.05)$ are referred to as similar in all of the experimental results and data comparisons.

\subsection{Protein contents of isolates and hydrolysates}

Amount of proteins in ten samples (two OBPI and eight OBPH) were analyzed using Lowry assay and expressed as a percentage of the total sample weights (Figure 11). Non-hydrolyzed protein isolates showed percentage protein contents of $77.94 \pm 1.27 \%$ and $82.11 \pm 1.85 \%$ for cellulase and viscozyme extracted protein isolates respectively, which were higher than the values for their hydrolysates. VAL and VPA had the highest protein content of $57.84 \pm 0.42 \%$ and $55.88 \pm 0 \%$ respectively compared to other OBPHs. Higher protein contents were found in viscozyme isolates hydrolyzed with alcalse and papain (VAL $(57.84 \pm 0.42 \%)$ and VPA $(55.88 \pm 0 \%)$ compared to hydrolysates of the same protease from cellulase extracted proteins (CAL $(35.78 \pm 0.42 \%)$ and CPA $(39.46 \pm 5.01 \%))$ and this may be due to differences in concentration of individual proteins in viscozyme and cellulase OBPIs. Alcalase and papain digested cellulase isolates $(\mathrm{CAL}$ and CPA) showed a similar $(\mathrm{p}<0.05)$ percentage protein content of $35.78 \pm 0.42 \%$ and $39.46 \pm 5.01 \%$ respectively. Cellulase and viscozyme hydrolysates (CPRO and VPRO) had similar protein content of $28.92 \pm 1.85 \%$ and $22.30 \pm 0.42 \%$ respectively. Flavourzyme digests, CFL and VFL, were also similar (Figure 11). The type of carbohydrase used to pre-treat oat bran did not affect the protein content of flavourzyme and protamex hydrolysates.

The protein content in the non-hydrolyzed samples are higher than that of hydrolyzed samples because each peptidase / protease used in the digestion of the protein isolates have different protein binding sites which is specific to each peptidase. Lowest values found in VFL and CFL indicated that flavourzyme was the least active of the proteases resulting in less breakdown of proteins regardless of the carbohydrase used for extraction. This is contrary to a work done by (C. Wang, Han, Feng, \& Dong, 2008) which found that protamex and flavourzyme produced hydrolysates with high protein contents, 
regardless of carbohydrase used for extraction. Alcalase and papain on the other hand, were certainly able to better hydrolyze (i.e. better degree of hydrolysis) proteins from viscozyme treated brans compared to those from cellulase treated brans. The composition of oats protein ranges from $15-20 \%$ by weight compared to the protein contents in other cereals such as wheat and barley which ranges between $8-15 \%$, therefore high protein contents in OBPI $(78-82 \%)$ observed in this assay indicates that extraction was efficient. The functionality and biological activity of the hydrolysates are then expected to be high (Singh et al., 2013).

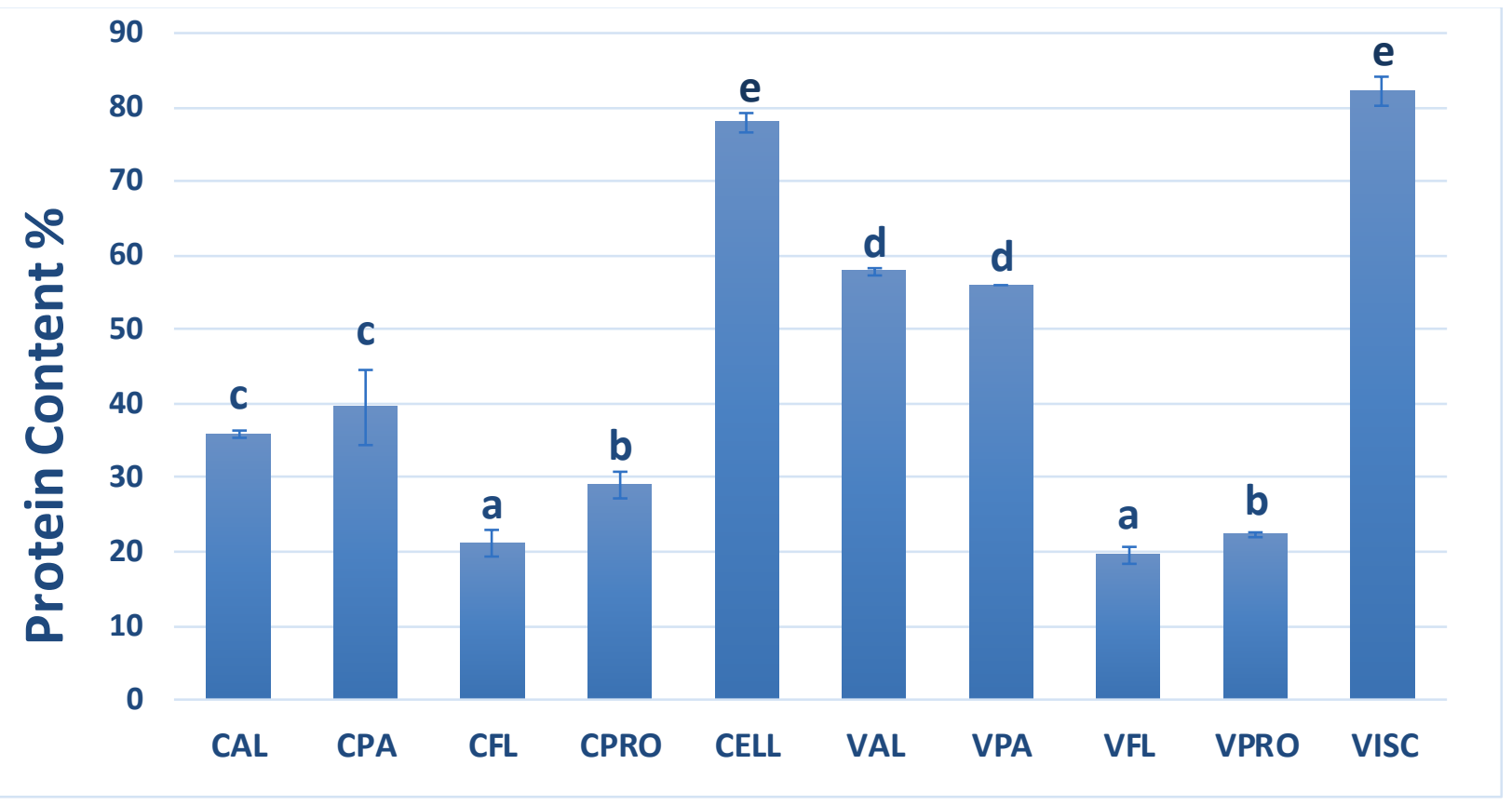

Figure 13: Protein content of oat bran hydrolysates as determined by Lowry assay, using Bovine se rum albumin (BSA) as standard. Peptide labels includes: Cellulase extracted; alcalase hydrolyzed sample (CAL), papain hydrolyzed sample (CPA), flavourzyme hydrolyzed s ample (CFL), protamex hydrolyze d s ample (CPRO), non-hydrolyze d sample (CELL), and Vis cozyme extracted; alcalase hydrolyze d sample (VAL), papain hydrolyzed sample (VPA), flavourzyme hydrolyzed sample (VFL), protamex hydrolyzed sample (VPRO), nonhydrolyzed sample. Each peptide was dissolved at $80 \mu \mathrm{g} / \mathrm{mL}$, tested in triplicates and are expressed as mean \pm SEM. Diffe re nt letter above each bar indicate significant differe nce as determined with Turkey's Honest Significance Differences (HSD) in one-way ANOVA ( $p$ value $<\mathbf{0 . 0 5}$ ) 


\subsection{Molecular weight distribution of samples}

The electrophoretic patterns indicating the molecular weight of oat bran protein isolates and hydrolysates are shown in figure 12. Non-hydrolyzed protein isolates extracted using cellulase (CELL) showed four minor protein bands with approximate MW of 15, 19, 20 and $27 \mathrm{kDa}$ while Viscozyme (VISC) extracted protein isolates showed two major (approx. MW of 20 and $35 \mathrm{kDa}$ ) and three minor protein bands (approx. MW of 25, 30 and $60 \mathrm{kDa}$ ). All of the hydrolysates treated with alcalase, papain, flavourzyme or protamex did not show any visible protein bands on the gel slabs, therefore assumed to have protein with molecular weight below $15 \mathrm{kDa}$.

VISC showed bands that were more intense and broad than those found in CELL. The thick bands (MW of 20 and $35 \mathrm{kDa}$ ) in the VISC isolate indicated that concentrations of these proteins were higher compared to those of CELL.

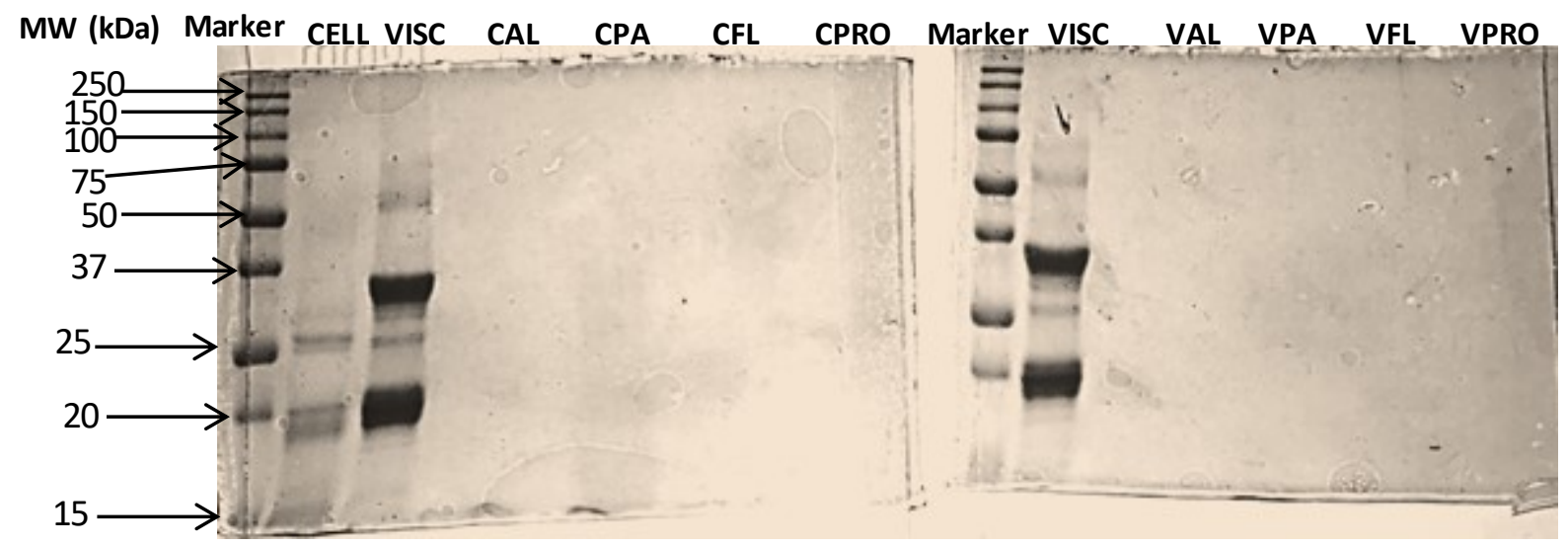

Figure 14: SDS-PAGE of isolates and hydrolysates dissolved in buffer containing $2 \%$ (v/v) 2me carptoe thanol. $10 \mu \mathrm{L}$ samples were run on gel slabs consisting of $12 \%$ separating gel (pH 8.6) and $5 \%$ stacking gel (pH6.8) for 1 hour at $120 \mathrm{~V}$. Biorad molecular-weight marker was used for molecular weight estimation.

There are acidic and basic polypeptide characterization of oat globulins (Mohamed et al., 2009). Protein bands observed for CELL samples are basic or $\beta$ - group $(15,19,20$ and $27 \mathrm{kDa})$ of polypeptide while VISC samples had two basic or $\beta(20,25 \mathrm{kDa})$ and three acidic or $\alpha$ - group $(30,35,60 \mathrm{kDa})$ of 
polypeptide. The pattern observed in Figure 12 is similar to that of oat globulins, indicating that globulins is the major protein component in OBPIs and is in agreement with previous report (Brinegar \& Peterson, 1982a). The $11 \mathrm{~S}$ or $12 \mathrm{~S}$ globulins (salt soluble proteins) (MW 60-70 kDa) are the dominant protein component for oats and the 3S (MW 15 and $21 \mathrm{kDa}$ ) or $7 \mathrm{~S}(55$ and $65 \mathrm{kDa})$ globulins are the minor protein component, both accounting for $50-80 \%$ of the seed protein (Klose \& Arendt, 2012; Koehler \& Wieser, 2013). Hence, it was concluded that the protein on figure 12 shows that the nonhydrolyzed samples VISC and CELL comprises of $3 \mathrm{~S}, 11 \mathrm{~S}$ or $12 \mathrm{~S}$ globulin and of the acidic and basic

subunits $(\alpha \& \beta)$. The hydrolyzed protein samples, assumed to have molecular weight less than $15 \mathrm{kDa}$, all showed comparable SDS-PAGE pattern despite the difference in their enzymatic hydrolysis. This is similar to results from other research on oat protein fractionation (Brinegar \& Peterson, 1982b; Klose \& Arendt, 2012) and oat protein hydrolysates (Guan et al., 2006). As mentioned earlier, globulins dominates oat proteins, however when compared to other cereals, prolamin dominates wheat, rye and barley (Burgess \& Shewry, 1986).

\subsection{Intrinsic Ultraviolet Absorbance}

Intrinsic ultraviolet absorbance of protein in oat bran proteins hydrolysates and isolates recorded at 280 $\mathrm{nm}$ are shown in Figure 13. Data from this experiment are used to relatively quantify the amount of chromophores in proteins that absorb light at $280 \mathrm{~nm}$. It was found that OBPIs had similar absorbance $(\mathrm{p}<0.05)$ meanwhile they were higher compared to most OBPHs. Two of the cellulase treated OBPHs, CPA and CFL, had the same level as the OBPIs, CELL and VISC. CAL had similar absorbance $(\mathrm{p}<0.05)$ as CPRO and VFL. VPA and VAL absorbed the least light (Figure 13). Several studies have demonstrated that proteins are capable of emitting prompt luminescence when excited with UV-light; thus the protein absorbance reveals different information about the protein, including the aromatic amino acid residues present in the protein (Bhattacharya et al., 2011). 
Phenylalanine, tyrosine and tryptophan are the 3 aromatic amino acids with intrinsic absorbance properties at $280 \mathrm{~nm}$; however tryptophan and tyrosine possess high absorbance when exposed to UVlight at wavelength $280 \mathrm{~nm}$ (Eftink, 2002). In proteins that consist of both tryptophan and tyrosine, tryptophan always dominates and gives the strongest absorption at wavelength $280 \mathrm{~nm}$ (Ghisaidoobe \& Chung, 2014). OBPI and OBPH samples with higher absorbance therefore contained higher residues of aromatic amino acids. Differences can also be attributed to the relative number of residues because a previous research showed that absorbance is low in proteins that contain tyrosine and no tryptophan (Goodwin \& Morton, 1946). Higher absorbance shown in non-hydrolyzed samples can be explained by the fact that some proteins that were not hydrolyzed in the presence of proteases were removed in the OBPH samples during centrifugation steps. The variation in absorbance of hydrolysates could be as a result of protease specificity and protein composition of OBPHs.

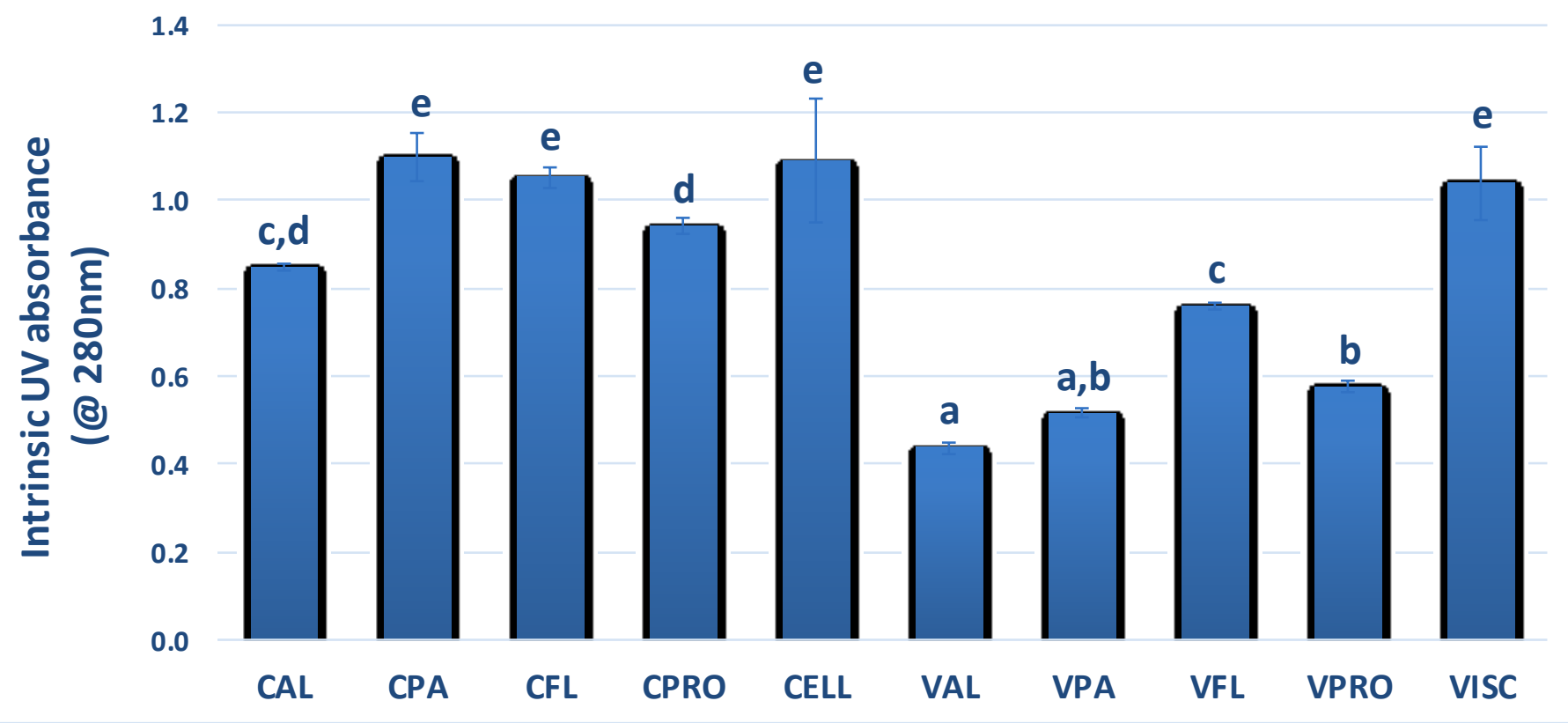

Figure 15: Ultraviolet absorbance of intrinsic protein in hydrolyzed and non-hydrolyzed oat bran prote in samples; absorbance reading recorded at wavelength $280 \mathrm{~nm}$ for amino acid residue. Hydrolyze d and non-hydrolyze d samples were prepared in $0.1 \mathrm{M}$ phosphate buffer (pH 7.0). Each sample was analyzed in triplicates and are expressed as mean \pm SEM. Diffe re nt letter above each bar indicate significant diffe re nce as de te rmined with Turkey's Honest Significance Diffe re nces (HSD) in one-way ANOVA ( $p$ value $<0.05$ ) 
It is anticipated that the samples with high aromatic amino residues will have high antioxidant properties because tryptophan and tyrosine are able to form stable radical intermediates after donating a proton as a result of their aromatic rings. It was demonstrated that peptides containing aromatic amino acid residues, tryptophan and tyrosine, possess radical scavenging properties (Pérez-González, Alvarez-Idaboy, \& Galano, 2015).

\subsection{Quantification of sulfhydryl (-SH) group}

In addition to aromatic amino acids, the presence of sulfur or thiol groups is important in antioxidant, chelating and reducing properties of hydrolyzed proteins. Thiols are a group of organic compounds that contain a sulfhydryl group (-SH). Free thiol such as in amino acid cysteine and peptide glutathione (GSH) are important for biological functions. The properties of methionine in peptides is also related to the presence of sulfur in the form of $-\mathrm{S}-\mathrm{CH}_{3}$, therefore, thiols are often quantified in proteins or their hydrolysates (Prakash, Shetty, Tilak, \& Anwar, 2009). The quantification is based on the reaction of 5,5'-dithio-bis-(2-nitrobenzoic acid) (DTNB) with free thiol groups present in the OBPI and OBPH samples to form a 2-nitro-5-thiobenzo ic acid (TNB) that absorbs at $412 \mathrm{~nm}$. Data (Figure 14) showed that OBPI samples, CELL and VISC, had similar $(p<0.05)$ free thiols $(-\mathrm{SH})$ and their contents were higher compared to their hydrolysates. Protein hydrolysates, CFL, VAL, VFL and VPRO had similar concentration of thiols (-SH). VPA had similar concentration as CPRO, CAL and CPA. 


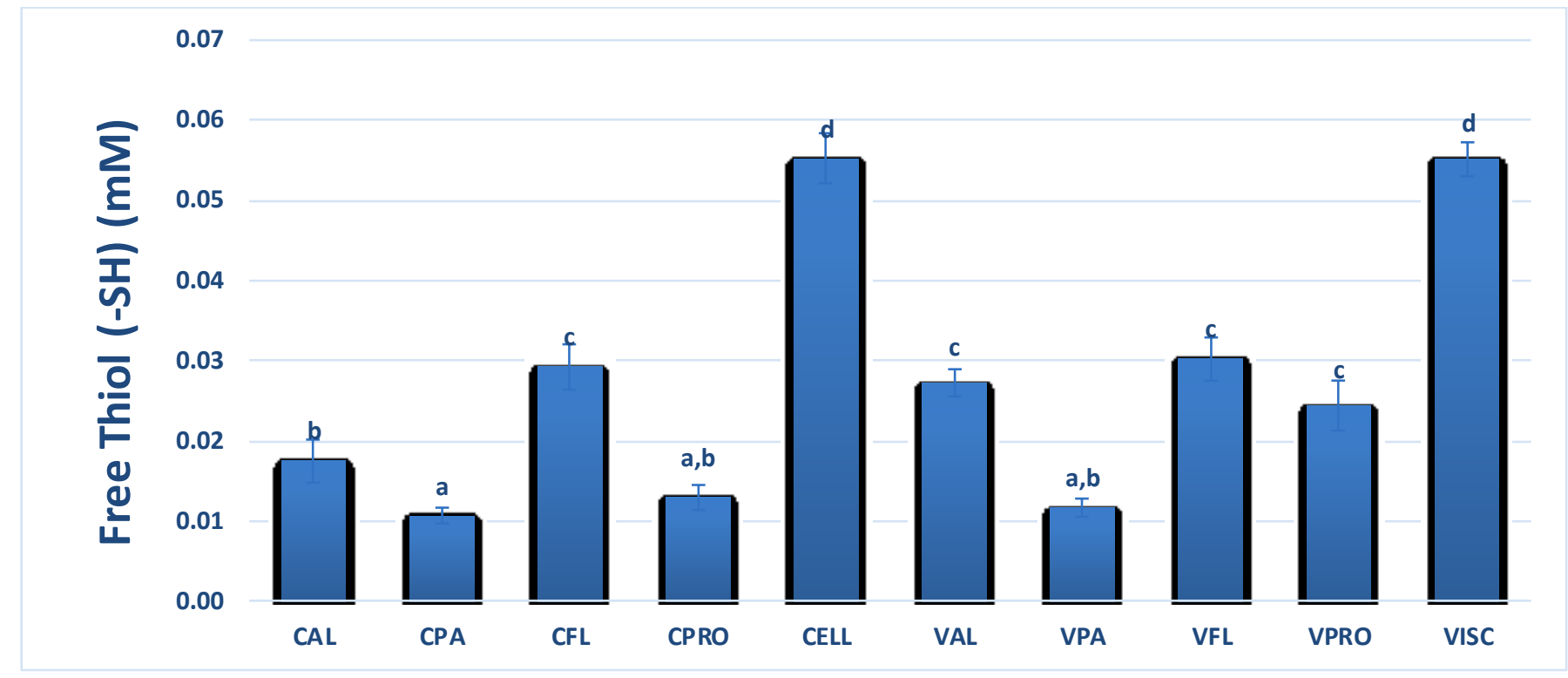

Figure 16: Free sulfhydryl groups in oat bran protein isolates and protein hydrolys ates. Each sample and control was analyzed in triplicates and are expressed as mean \pm SEM. Diffe rent letter above each bar indicate significant difference as determined with Turkey's Honest Significance Differe nces (HSD) in one-way ANOVA $(p$ value $<0.05)$

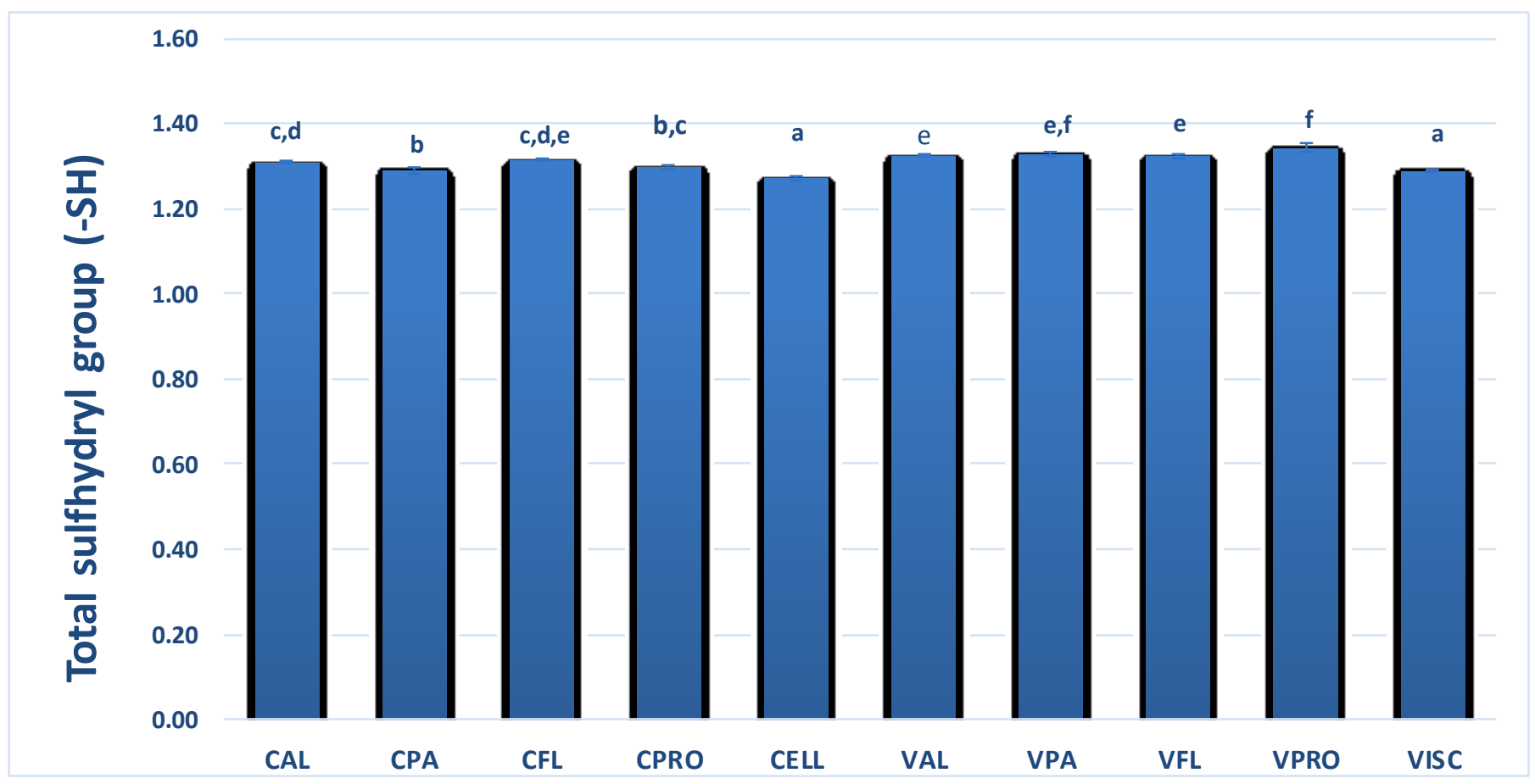

Figure 17: Total sulfhydryl groups in oat bran prote in is olates and prote in hydrolys ates. Dis ulphide bonds were hydrolyzed with 2 -mecaptoethanol. Each sample and control was analyzed in triplicates and is expressed as mean \pm SEM. Different letter above each bar indicate significant differe nce as de termined with Turkey's Honest Significance Diffe rences (HSD) in one-way ANOVA $(p$ value $<0.05)$. 
Total sulfhydryl group were analyzed in samples treated with 2-mecaptoethanol, a reagent that breaks disulfide bonds in proteins (Equation 15).

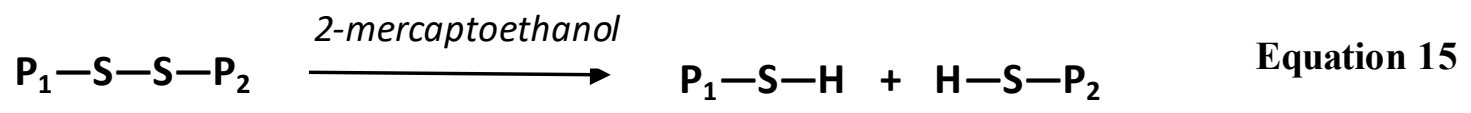

Data (figure 14) showed that OBPHs from viscozyme treated brans had highest total thiols compared to those from cellulase treatment. Overall, differences in total thiol are not as pronounced as free thiols indicate samples had different amount of proteins or peptides containing disulfide bonds. OBPHs had higher concentration of total thiol compared to OBPIs indicating that there were more disulfide bonds in hydrolysates than in intact proteins. OBPHs from viscozyme treated brans had similar concentration of total thiol. CPA had similar concentration as CPRO, and CPRO had similar concentration as CPA and CFL. Therefore, the protein hydrolysates from viscozyme had higher disulphide-bonded thiols (-S-S) that were readily available to be broken down by 2-ME to produce the total thiols (-SH). The 2mecaptoethanol has been used in many studies to hydrolyze disulphide to form free thiols (-SH) (Mirsky, 1936). Similar trend was observed in another research that investigated the thiol contents in cereal samples before and after hydrolysis with a reducing agent (Chan \& Wasserman, 1993). Estimation of total thiol in protein hydrolysates is useful in understanding their ability to reduce oxidative stress because they can serve as reducing agents in the cell or be preferentially oxidized by reactive oxygen species.

\subsection{Oxygen radical absorbance capacity (ORAC) assay}

The ORAC assay that measures peroxyl radical (ROO ${ }^{\circ}$ ) scavenging activity is often used to characterize the antioxidant activity of chemicals, food and biological samples. Data (Figure 16) showed that cellulase and viscozyme treated OBPHs had ORAC values higher $(p<0.05)$ than OBPIs. This is in agreement with literature data because hydrolysis produces smaller molecular weight 
fragments that generally interact better with $\mathrm{ROO}^{\bullet}$ radicals ( K Zhu, Zhou, \& Qian, 2006, Udenigwe \& Aluko, 2012). Although CELL-OBPI had a higher ORAC value $(305 \pm 28 \mu \mathrm{M} \mathrm{TE} / \mathrm{g})$ compared to VISC-OBPI (107 $\pm 12 \mu \mathrm{M} \mathrm{TE/g),} \mathrm{most} \mathrm{CELL-OBPHs} \mathrm{had} \mathrm{lower} \mathrm{activities} \mathrm{compared} \mathrm{to} \mathrm{VISC-OBPHs.}$ This can be explained by the difference in protein composition of the two OBPIs. Amongst the hydrolysates, those from protamex, and papain had similar value regardless of the carbohydrase used in pre-treatment steps. All samples better scavenge peroxyl radical than control (GSH). Higher peroxyl radical scavenging activity found in OBPHs compared to OBPIs is because the hydrolysis broke peptide bonds and then resulted in smaller weight fragments as demonstrated by the SDS-PAGE data. Many studies have shown that antioxidant peptides generally have smaller molecular weights (K Zhu, Zhou, \& Qian, 2006, Udenigwe \& Aluko, 2012). ORAC values obtained in this research is higher than the ORAC values from other studies on oat bran protein isolates; $15.9 \pm 1.9$ to $25.4 \pm 3.2 \mu \mathrm{M} \mathrm{TE} / \mathrm{g}$ (Alrahmany \& Tsopmo, 2012b) and hydrolyzed oat proteins; $294 \pm 4$ to $434 \pm 16 \mu \mathrm{M} \mathrm{TE} / g$ (Jodayree et al., 2012). Hydrolysates had aromatic amino acids (Figure 13) in addition to thiols of disulfide bonds, all of which can contribute to their antioxidant activities. Thiol containing peptides have been shown to possess strong peroxyl radical scavenging activity, hence reducing oxidative damage to cells and food products (Andersson, Lindgren, \& Hultberg, 1995; Valko et al., 2005). Amino acid sequences of peptides in each hydrolysate were not determined in this research; it would have been possible to identify what amino acid residue is present in each hydrolysate sample. The position of the amino acid residue and the length of the peptides have been shown to contribute to the antioxidant activity of protein hydrolysates (Hm Chen, Muramoto, Yamauchi, Fujimoto, \& Nokihara, 1998). The difference in the oxygen radical scavenging properties of the samples could also be due to the selectivity of the peptidase and their reaction rate (Je et al., 2009). 


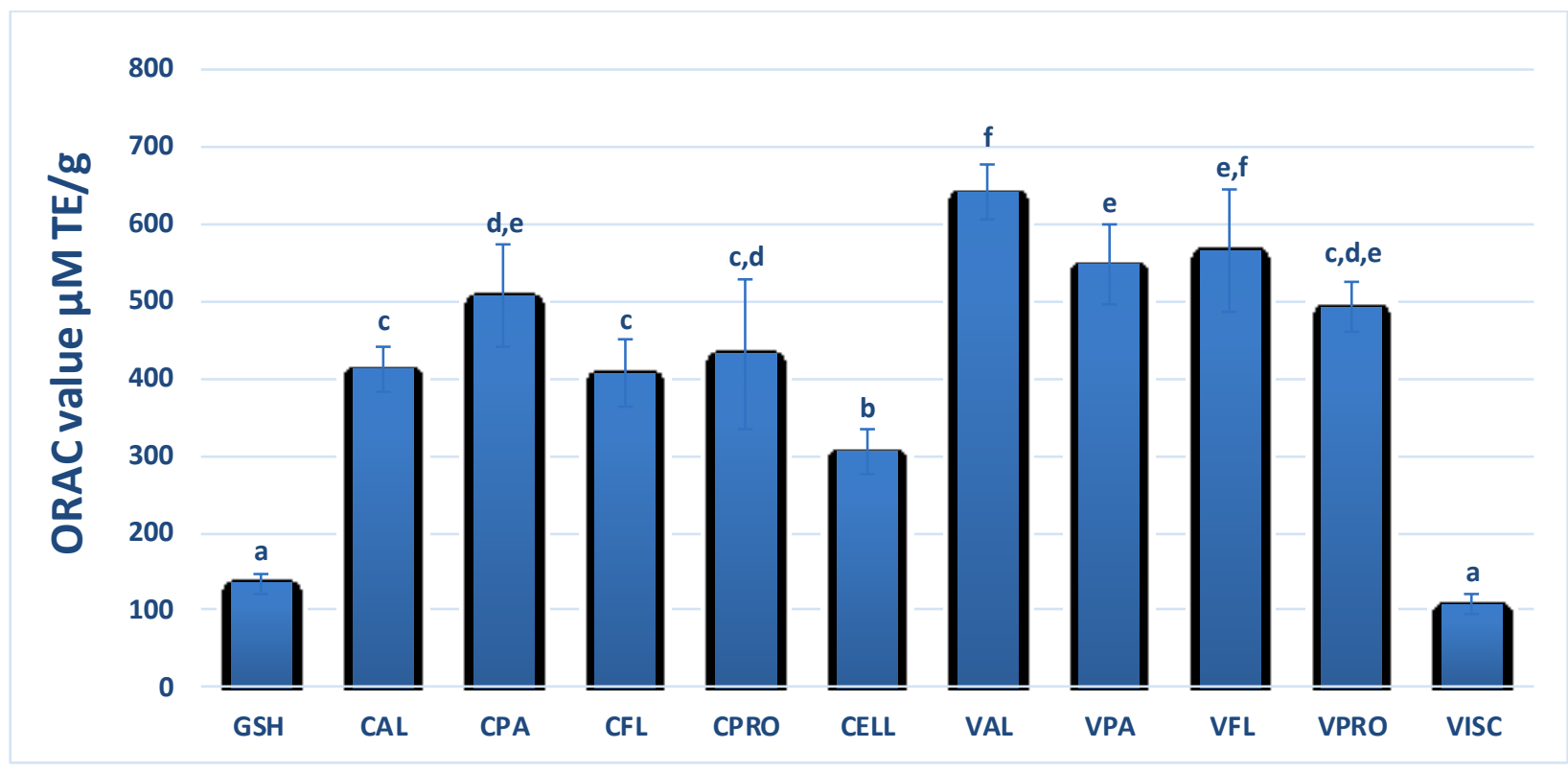

Figure 18: Antioxidant activity (ORAC value $\mu M$ TE/g sample) of OBPI and OBPH samples. Each sample and control (GSH) was analyzed in triplicates and is expressed as mean \pm SEM. Diffe re nt letter above each bar indicate significant diffe re nce as de te rmined with Turkey's Honest Significance Diffe re nces (HSD) in one-way ANOVA ( $p$ value $<0.05$ ).

\subsection{Hydroxyl radical $\left(\mathrm{HO}^{\circ}\right)$ scavenging activity}

Hydroxyl radical is the most reactive free radical formed from the reaction of hydrogen peroxide and superoxide anion as shown in section 2.1.1.2. Hydroxyl radical react with proteins, polypeptide, lipids and DNA in the presence of metal ions such as copper or iron, hence causing damages to these biomolecules (Noori, 2012). Hydroxyl radical was generated in this study using a Fenton-like $\mathrm{Fe}^{2+} / \mathrm{H}_{2} \mathrm{O}_{2}$ reaction. $\mathrm{HO}^{\bullet}$ scavenging activity of OBPI and $\mathrm{OBPH}$ samples, as well as control, were investigated and expressed as $\% \mathrm{HO}^{\bullet}$ inhibition as shown in Figure 17. OBPI samples, CELL and VISC, had the highest $\% \mathrm{HO}^{\bullet}$ scavenging activities compared to OBPHs and control. OBPIs and OBPHs behave differently in scavenging peroxyl radicals (ORAC assay) and hydroxyl radical ( $\left.\mathrm{HO}^{\bullet}\right)$ because $\mathrm{HO}^{\bullet}$ scavenging activity depends on the ability of an antioxidant compound to act as a reducing agent, a hydrogen donor and a scavenger of active oxygen (Rice-evans, Miller, \& Bolwell, 1995). OBPIs may have more hydrophobic amino acids in their sequence. VAL, CPA and CPRO had similar $(\mathrm{p}<0.05) \%$ $\mathrm{HO}^{\bullet}$ scavenging ability of $8.6 \pm 1.4 \%, 7.9 \pm 0.6 \%, 6.6 \pm 1.1 \%$ respectively. CAL, VFL and VPRO 
had similar $(\mathrm{p}<0.05) \% \mathrm{HO}^{\bullet}$ scavenging ability as GSH (control). CFL and VPA had the highest \% $\mathrm{HO}^{\bullet}$ scavenging capacity of $13.7 \%$ compared to most OBPHs and control. OBPIs and OBPHs, showed a minimum $\% \mathrm{HO}^{\bullet}$ scavenging capacity of $7.9 \%$ and a maximum of $21 \%$. The difference in $\mathrm{HO}^{\bullet}$ scavenging properties of the samples may be due to differences in their amino acid composition and the positioning of the amino acid on the peptide sequence. Research showed that proteins / peptides with intrinsic and hydrophobic amino acids at the $\mathrm{N}$-terminus or the third position adjacent to the $\mathrm{C}$-terminus enhances their antioxidant activities (Wattanasiritham, Theerakulkait, \& Wickramasekara, 2016). High $\% \mathrm{HO}^{\bullet}$ scavenging capacity of the samples could be due to the presence of Histidine in the protein hydrolysates and isolates, which has been shown to be a metal chelator and a hydroxyl radical scavenger (Hm Chen et al., 1998).

\subsection{Superoxide radical $\left(\mathrm{O}_{2}^{-\bullet}\right)$ scavenging activity}

Superoxide anion is a reduced form of molecular oxygen, known to be very harmful ROS to cellular components when produced in excess, and a precursor to more reactive oxygen specie such as hydroxyl radical. Superoxide anion was generated by pyrogallol autoxidation reaction, which univalently reduces molecular oxygen (Aruoma, 1998), then the rate of reaction was used to calculate the scavenging activity. The reaction rate of pyrogallol autoxidation decreases in the presence of $\mathrm{O}_{2}^{-\bullet}$ scavenger. Data (Figure 18) showed that OBPI and OBPH samples had lower $\% \mathrm{O}_{2}^{-\bullet}$ scavenging capacity compared to GSH (control) with $67 \pm 1.5 \%$ capacity. OBPI samples, CELL and VISC, had similar $(\mathrm{p}<0.05) \% \mathrm{O}_{2}^{-\bullet}$ scavenging activity of $28.6 \pm 5.6 \%$ and $28 \pm 2.7 \%$ respectively. Some of the OBPHs, CAL, CPA and CFL, had higher $\% \mathrm{O}_{2}{ }^{-\bullet}$ scavenging activity ranging from $37.5 \pm 1.5 \%$ to $39.3 \pm 4.1 \%$ compared to OBPIs. CPRO, VAL, VPA, VFL and VPRO all had similar $(\mathrm{p}<0.05) \% \mathrm{O}_{2}^{-\bullet}$ scavenging activity ranging from $28.6 \pm 6.7 \%$ to $34.8 \pm 1.5 \%$. CAL, CPA, CFL and CPRO had higher $\% \mathrm{O}_{2}^{-\bullet}$ scavenging activity ranging from $34.8 \pm 1.5 \%$ to $39.3 \pm 4.1 \%$. The superoxide radical scavenging capacity of 
OBPIs and OBPHs in this study is similar to that obtained from a research by (Baakdah \& Tsopmo, 2016), where the activity of GSH is much higher than their protein isolate and hydrolysate samples. Protein isolates and hydrolysates from other food sources (such as soymilk, berry crops, and leaf extracts) have been reported to possess varying superoxide radical scavenging activity (Pavithra \& Vadivukkarasi, 2015; S. Y. Wang \& Jiao, 2000; Y.-C. Wang, Yu, \& Chou, 2006). The presence of indole group in tryptophan has been shown to increase the superoxide anion scavenging activity of tryptophan-containing peptides (Höhn, König, \& Grune, 2013). OBPIs and OBPHs samples has been shown to contain aromatic amino acids, hence their superoxide radical scavenging activity. A positive correlation (correlation coefficient +1 ) was obtained between $\mathrm{O}_{2}^{-\bullet}$ scavenging activity (Figure 17) and Intrinsic UV absorbance (Figure 13).

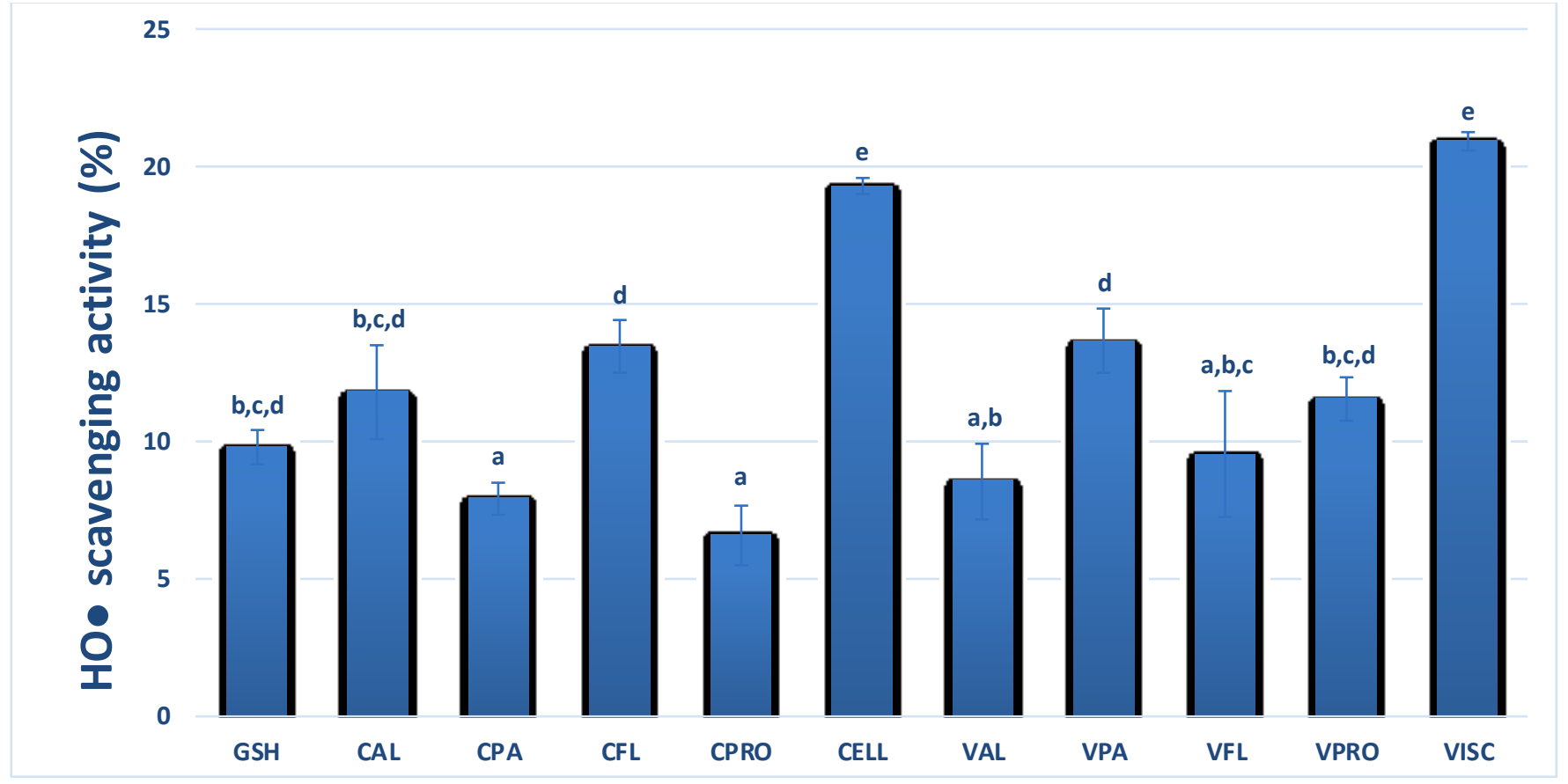

Figure 19: Hydroxyl radical scavenging activity of OBPI and OBPH samples. Each sample and control (GSH) was analyzed in triplicates and is expressed as me an \pm SEM. Diffe rent le tte $r$ above each bar indicate significant difference as determined with Turkey's Honest Significance Differences (HSD) in one-way ANOVA $(p$ value $<0.05)$. 


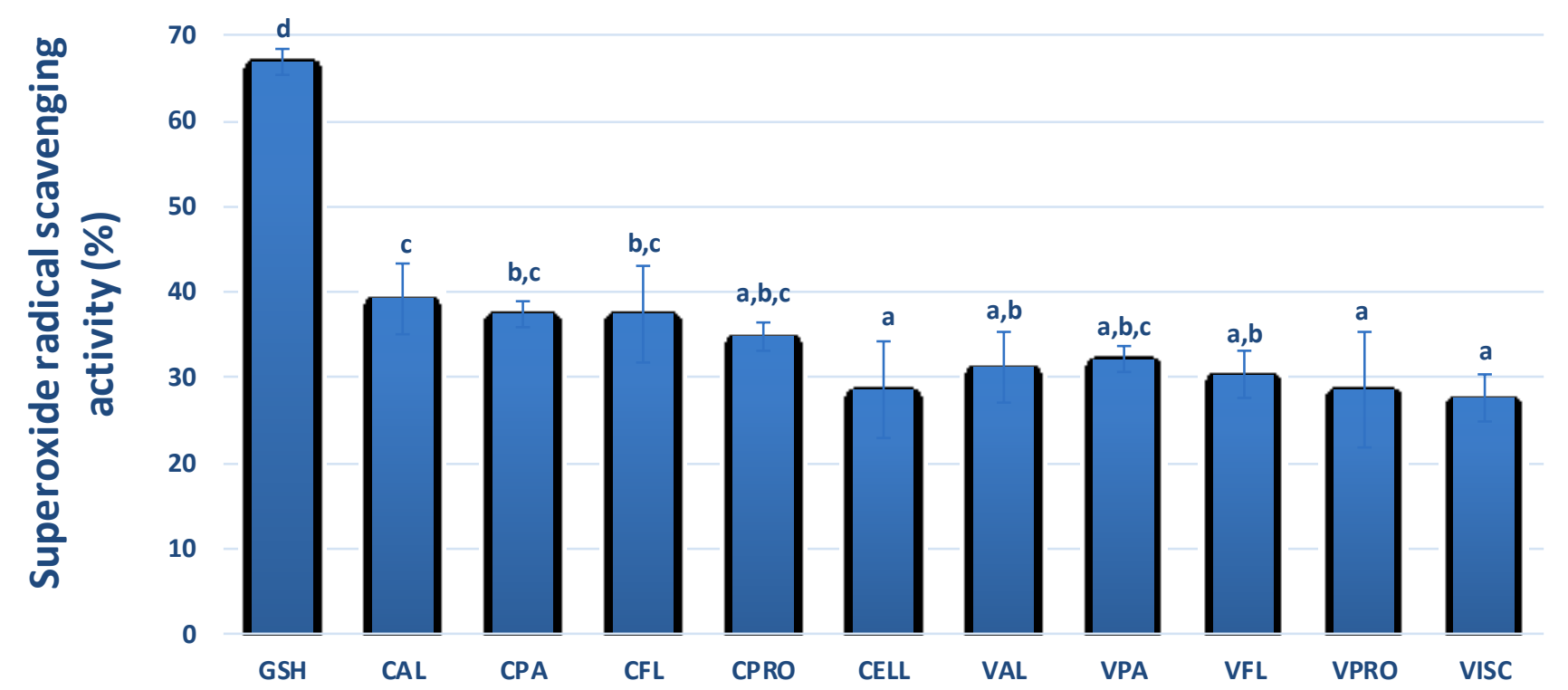

Figure 20: Superoxide radical scavenging activity of OBPI and OBPH samples. Each sample and control (GSH) was analyzed in triplicates and expressed as mean \pm SEM. Diffe rent letter above each bar indicate significant difference as determined with Turkey's Honest Significance Differences (HSD) in one-way ANOVA $(p$ value $<0.05)$.

\subsection{Inhibition of lipid peroxidation in meat}

Unsaturated fatty acids such as oleic, linoleic and linolenic acids undergo autoxidation by losing hydrogen atom to a free radical. Polyunsaturated fatty acids in foods does not react with ground state oxygen, however in the presence of an initiator, they can form a carbon centered radical which in turn can react with oxygen to form peroxyl radicals $\left(\mathrm{ROO}^{\bullet}\right)$ and hydroperoxides $(\mathrm{ROOH})$. The reaction between the oxidized lipids (i.e. hydroperoxide or lipid peroxide) and ferrous iron is used to quantify their amount in foods and biological samples. In the absence of an antioxidant, there may be high color intensity $(560 \mathrm{~nm})$ due to greater lipid peroxides. The ability of OBPIs and OBPHs, at a final concentration of $1 \mathrm{mg} / \mathrm{g}$ of meat sample, to inhibit or reduce lipid peroxidation in meat (chicken breast) was investigated and expressed as $\mu \mathrm{M} \mathrm{H}_{2} \mathrm{O}_{2} / \mathrm{g}$ of meat (Figure 19). Data showed that in non-stored (NS) samples (i.e. immediately after homogenization with or without OBPI/OBPH), meat treated with CFL, VPA or VPRO did not change $(\mathrm{p}<0.05)$ the concentration of lipid peroxides when compared to 
control (no protein or hydrolysates), while other OBPHs and OBPIs increased oxidation of lipids

(Figure 19). Samples stored at $4{ }^{0} \mathrm{C}$ further increased concentration of lipid peroxides by up to 4.5 fold compared to NS samples. At this temperature $\left(4{ }^{0} \mathrm{C}\right)$, all cellulase treated OBPHs (CAL, CPA, CFL, and CPRO) had higher $(\mathrm{p}<0.05)$ activity in inhibiting lipid peroxidation compared to viscozyme. VPA increased oxidation, while VFL and VPRO had no effect. Amongst the OBPIs, VISC had no effect while CELL increased peroxidation. The extent of oxidation was 1 - to 3 -fold lower at $-20{ }^{0} \mathrm{C}$ compared to $4{ }^{0} \mathrm{C}$ but still higher compared to NS. At $-20{ }^{0} \mathrm{C}$, VFL and VPRO had lower concentration compared to other OBPHs, which had no effect on peroxidation except CFL, which had a higher concentration compared to control. Amongst the OBPIs, VISC showed peroxidation inhibiting activity while CELL increased peroxidation compared to control.

Peptides containing hydrophobic amino acids in their sequence has been shown to reduce/prevent lipid peroxidation by donating hydrogen to peroxyl radical $\left(\mathrm{ROO}^{\bullet}\right)$, hence neutralizing the radicals in the propagation step in lipid peroxidation mechanism (HM Chen, Muramoto, \& Yamauchi, 1995; Davalos, Miguel, \& Bartolome, 2004; Suetsuna, Ukeda, \& Ochi, 2000). When comparing all the three different condition, it was observed that OBPIs and OBPHs had varying lipid peroxide inhibition activity at different temperatures due to the differences in their amino acid composition and hydrophobicity, however at $-20{ }^{0} \mathrm{C}$, they are most active in preventing or reducing lipid oxidation. Protein isolates and hydrolysate from other food sources has been shown to inhibit lipid peroxidation (Y. Li, Jiang, Zhang, Mu, \& Liu, 2008; Xie, Huang, Xu, \& Jin, 2008; K Zhu, Zhou, \& Qian, 2006). The isolation of these antioxidant peptides in the OBPHs can be used by food industries to prevent lipid peroxidation in food products. Further research on the hydrophobicity of the OBPHs and OBPIs will help to further characterize them. 


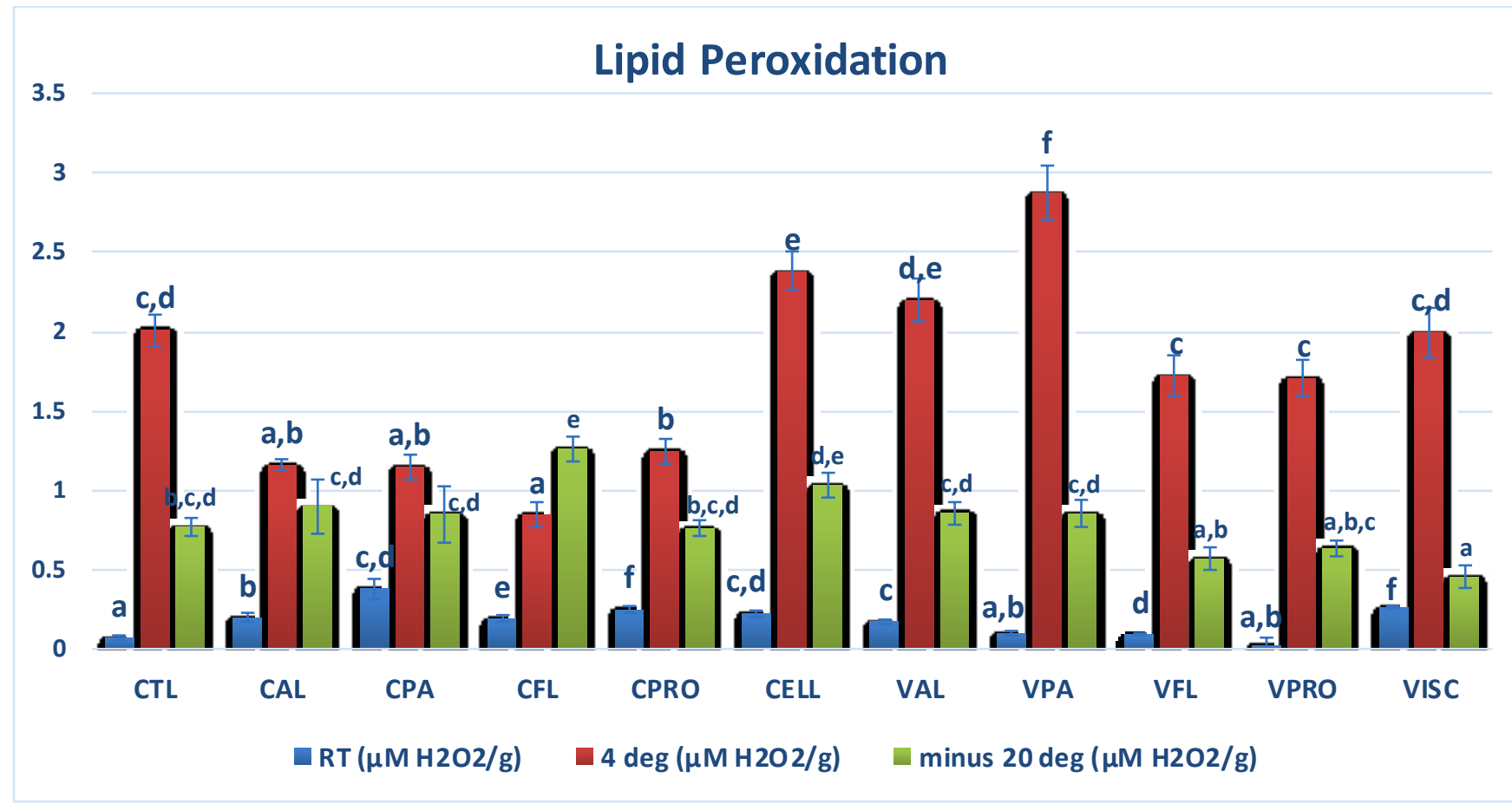

Figure 21: Lipid peroxidation inhibition of OBPI and OBPH samples. Each sample and control (untre ated) was analyzed in triplicates and expressed as me an \pm SEM. Each series indicate analysis with no storage (NS) and after 24 hours storage at $4{ }^{\circ} \mathrm{C}$ and $-20{ }^{\circ} \mathrm{C}$. Different letter above each bar indicate significant difference within the same series as determined with Turkey's Honest Significance Differences (HSD) in one-way ANOVA $(p$ value $<0.05)$.

\subsection{Effect of protein isolates and hydrolysates on arsenic in meat}

Arsenic is a widely known toxic metal and a carcinogen, especially the trivalent form (As (III)). One of its mechanisms of toxicity involves the formation of reactive oxygen species (ROS) in the cell. As (III) has been shown to inhibit the activity of glutathione, which protects the cell against oxidative damage, thereby leading to a disturbance in DNA repair system, hence contributing to an increased level of oxidative stress and damages in the cell (Beyersmann \& Hartwig, 2008). The concentration of arsenic species at different storage conditions was determined by HPLC-ICP-MS in meat samples treated with OBPIs or OBPHs. A batch of the samples were analyzed immediately after treatment while other batches were either stored at $4{ }^{0} \mathrm{C}$ or $-20{ }^{0} \mathrm{C}$ for 24 hours before analysis. 
In non-stored samples (NS), there was an increase in As (III) in all OBPI and OBPH treated samples compared to the control (untreated samples). This might be because of the affinity of As (III) with thiol groups or other functional groups in OBPIs and OBPHs. Amongst samples, CELL and CFL had the highest $(\mathrm{p}<0.05)$ concentrations of As (III) compared to VISC, CAL, CPA, CPRO, VFL and VPRO which had similar $(\mathrm{p}<0.05)$ concentrations. The concentration of As $(\mathrm{V})$ observed in samples treated with OBPIs and OBPHs are similar $(\mathrm{p}<0.05)$ to the control (untreated).

Samples stored at $4{ }^{0} \mathrm{C}$ further increased concentration of As (III) and decreased concentration of As (V) compared to NS samples. Amongst samples, CPRO and VISC had the highest concentrations of As (III) compared to CAL, CPA, VAL, and VPA which had similar $(\mathrm{p}<0.05)$ concentrations. The concentration of As (III) in CELL, CFL, VFL, and VPRO was similar $(p<0.05)$ to control. Concentration of As (V) in all OBPI and OBPH treated samples were similar $(\mathrm{p}<0.05)$ except CAL which had a higher concentration.

At $-20{ }^{0} \mathrm{C}$, OBPI and OBPH treated samples had higher concentration of As (III) compared to NS, but mostly lower concentration compared to $4{ }^{0} \mathrm{C}$. Concentration of As (V) in treated samples is mostly lower compared to NS and $4{ }^{0} \mathrm{C}$. Amongst all samples, VPA and VFL had highest concentration of As (III), compared to CAL, CPA, CPRO, CFL and VPRO which had similar $(\mathrm{p}<0.05)$ concentrations. VAL, CELL and VISC had similar $(\mathrm{p}<0.05)$ concentration of As (III). VISC, CAL, CPA, and CFL had similar $(\mathrm{p}<0.05)$ concentration of As $(\mathrm{V})$ compared to control, while CELL, CPRO, VAL, VPA, VFL and VPRO had similar $(\mathrm{p}<0.05)$ concentration of As $(\mathrm{V})$, lower than control.

Data (Figure 20A-C) showed that in NS and samples stored at $4{ }^{0} \mathrm{C}$ or $-20{ }^{0} \mathrm{C}$, there were little changes in concentrations of As (V). This was an implication that As (V) was not reduced to As (III) upon treatment of samples with OBPIs or OBPHs or upon storage. The increase in concentrations of As (III) in treated samples might be due to its binding to proteins or peptides present in OBPI and OBPH. In addition to preventing oxidation of trivalent arsenic to pentavalent arsenic in treated samples, OBPIs and 
OBPHs were also able to prevent the reduction of pentavalent arsenic to trivalent arsenic. The levels of arsenic obtained from this study were much lower $(\mathrm{ng} / \mathrm{mL})$ compared to the regulated levels allowed in foods $(0.5-2 \mathrm{mg} / \mathrm{L})$ (U.S. FDA). Literature data indicated that thiol containing molecules can bind to As (III) and this may be the reason why the amount of As (III) increased in OBPI and OBPH treated samples. There was 58\% correlation observed between As (III) and sulphydryl groups (Figure 14) present in OBPI and OBPH. One of the thiol that binds to As (III) is the endogenous antioxidant tripeptide, GSH. Toxicity of As (III) in biological systems is mainly due to protein binding (i.e. loss of function), oxidative stress and altered DNA methylation (Kitchin \& Ahmad, 2003; Kitchin \& Wallace, 2008; Menzel et al., 1999). Arsenic-binding peptides from hydrolyzed food proteins, if bioavailable, can therefore mitigate the toxicity of arsenic in biological systems. Additionally, data from this work showed that hydrolyzed proteins can be used to enhance the quantification of arsenic species in meat. 

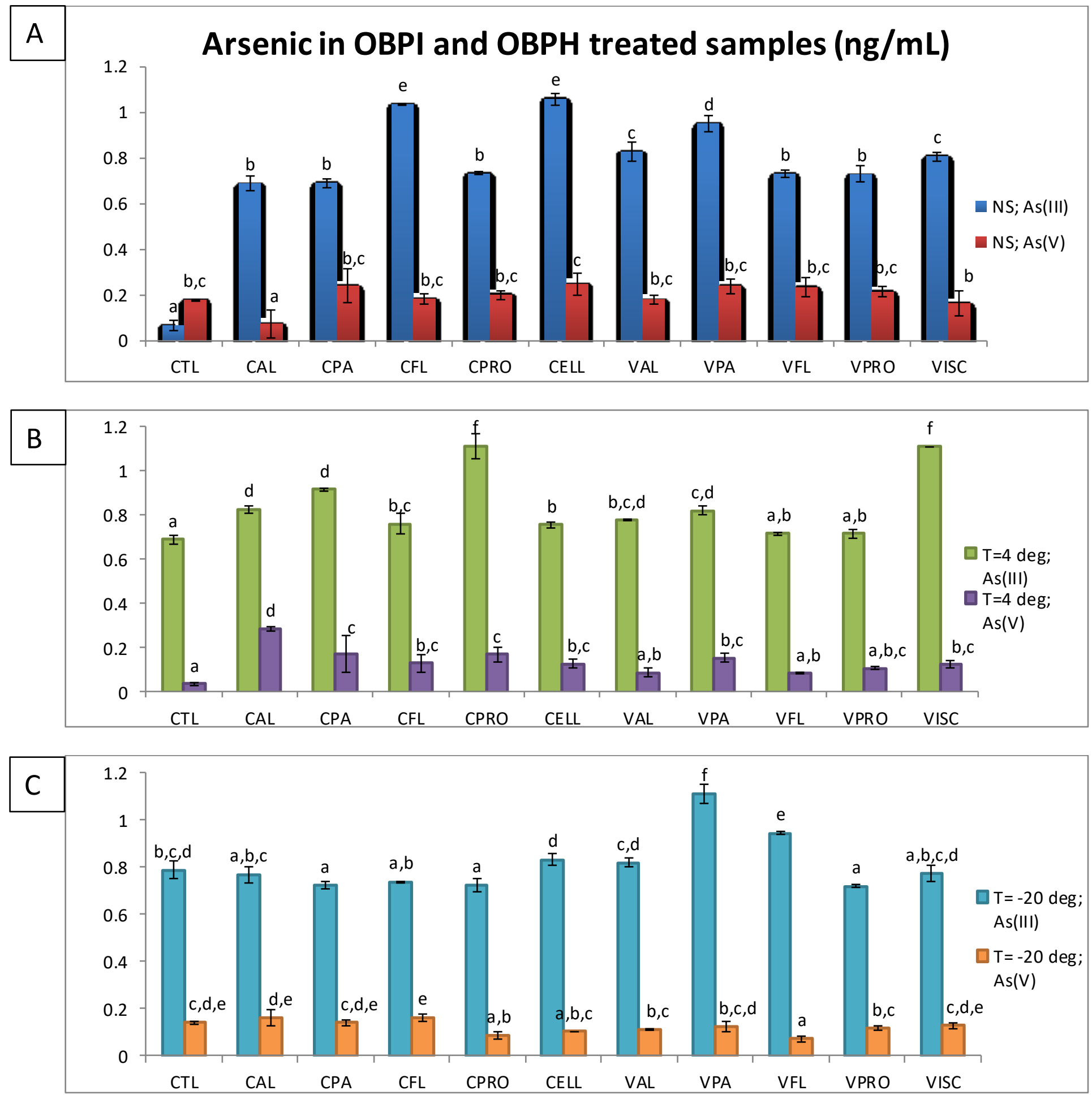

Figure 22: Effect of protein isolates and hydrolysates on arsenic species; trivale nt (As (III)) and pentavalent $(\mathrm{As}(\mathrm{V}))$. Each sample and control (untre ated) was analyzed in triplicates and expressed as mean \pm SEM. Each series indicate analysis with (A) no storage (NS), (B) storage at $4{ }^{\circ} \mathrm{C}$ for 24 hours and (C) storage at $-20{ }^{\circ} \mathrm{C}$ for $24 \mathrm{hrs}$. Different le tter above each bar indicate significant diffe rence within the same series as de te rmined with Turkey's Honest Significance Diffe re nces (HSD) in one-way ANOVA ( $p$ value $<0.05$ ). 


\subsection{Chromium reducing activity}

Hexavalent chromium ( $\mathrm{Cr}(\mathrm{VI})$ ) is a known carcinogen. Once $\mathrm{Cr}(\mathrm{VI})$ is being transported into the cell membrane, the steps involved in its metabolism into $\mathrm{Cr}$ (III) generate free radicals. $\mathrm{Cr}$ (VI) toxicity is mitigated by reducing molecules such as glutathione (GSH). This experiment was conducted to determine if there were molecules in oat protein isolates or hydrolysates capable of reducing $\mathrm{Cr}$ (VI) to $\operatorname{Cr}($ III).

In non-stored samples (NS), concentrations of $\mathrm{Cr}(\mathrm{VI})$ decreased in all treatment compared to control while the concentration of $\mathrm{Cr}$ (III) increased in six samples (CAL, CFL, VAL, VPA, VFL, and VPRO), four of which were hydrolysates of VISC proteins. The combination of decreased $\mathrm{Cr}(\mathrm{VI})$ and increased $\mathrm{Cr}$ (III) contents is an indication of the reducing power of OPBH samples. Immediately after homogenization, the most reducing sample was CAL which had the highest concentration of Cr (III). The concentrations of $\mathrm{Cr}$ (III) in CPA, CPRO, CELL, and VISC were similar $(p<0.05)$ to control meaning that there were possibly no reductive effects on $\mathrm{Cr}(\mathrm{VI})$ species.

Samples stored at $4{ }^{0} \mathrm{C}$ further increased concentration of $\mathrm{Cr}$ (III) and decreased $\mathrm{Cr}$ (VI) compared to NS. At this temperature $\left(4{ }^{0} \mathrm{C}\right)$, concentration of $\mathrm{Cr}(\mathrm{VI})$ decreased in all treatment compared to control while the concentration of $\mathrm{Cr}$ (III) increased in five samples (CPA, CFL, CPRO, VAL, and VPRO), three of which were hydrolysates of CELL protein. Compared to NS and $4{ }^{0} \mathrm{C}$, samples stored at $-20{ }^{0} \mathrm{C}$ generally had lower concentration of $\mathrm{Cr}$ (VI) and higher concentrations of $\mathrm{Cr}$ (III). At this temperature $\left(-20{ }^{0} \mathrm{C}\right)$, the concentration of $\mathrm{Cr}(\mathrm{VI})$ decreased significantly $(\mathrm{p}<0.05)$ in all treatments except in VPA, compared to control while the concentration of $\mathrm{Cr}$ (III) increased in five samples (CAL, CPA, CPRO, VAL and VPRO), three of which were hydrolysates of CELL protein. Hexavalent chromium reducing activity of OBPIs and OBPHs at different temperature varies slightly as shown in Figure 21A-C.

Studies have shown that cellular reductant and thiol containing molecules such as GSH and ascorbate reduces Cr (VI) (Xianglin Shi, 1999; Wiegand, Ottenw, \& Bolt, 1984). Oat bran protein hydrolysates 
has been shown to reduce $\mathrm{Cr}(\mathrm{VI})$, however the concentration or percentage at which $\mathrm{Cr}$ (III) increased was not shown or mentioned in any previous study. OBPIs and/or OBPHs with lower concentration of $\mathrm{Cr}$ (VI) and higher concentration of $\mathrm{Cr}$ (III) were concluded to have $\mathrm{Cr}(\mathrm{VI})$ reducing activity. $\mathrm{Cr}$ (VI) reduction could be by its reaction with the peptides from hydrolyzed food proteins to generate $\mathrm{Cr}$ (III). The reduction of $\mathrm{Cr}(\mathrm{VI})$ to $\mathrm{Cr}$ (III) has been shown to generate superoxide anion and hydroxyl radical partially responsible for DNA, lipid and blood cell damages (X Shi et al., 1998), however, OBPI and OBPH have been shown in this study to possess superoxide anion and hydroxyl radical scavenging activities. For future studies, an in vivo study on the effect of OBPI and OBPH in reducing hexavalent chromium would be an interesting area of future research. 

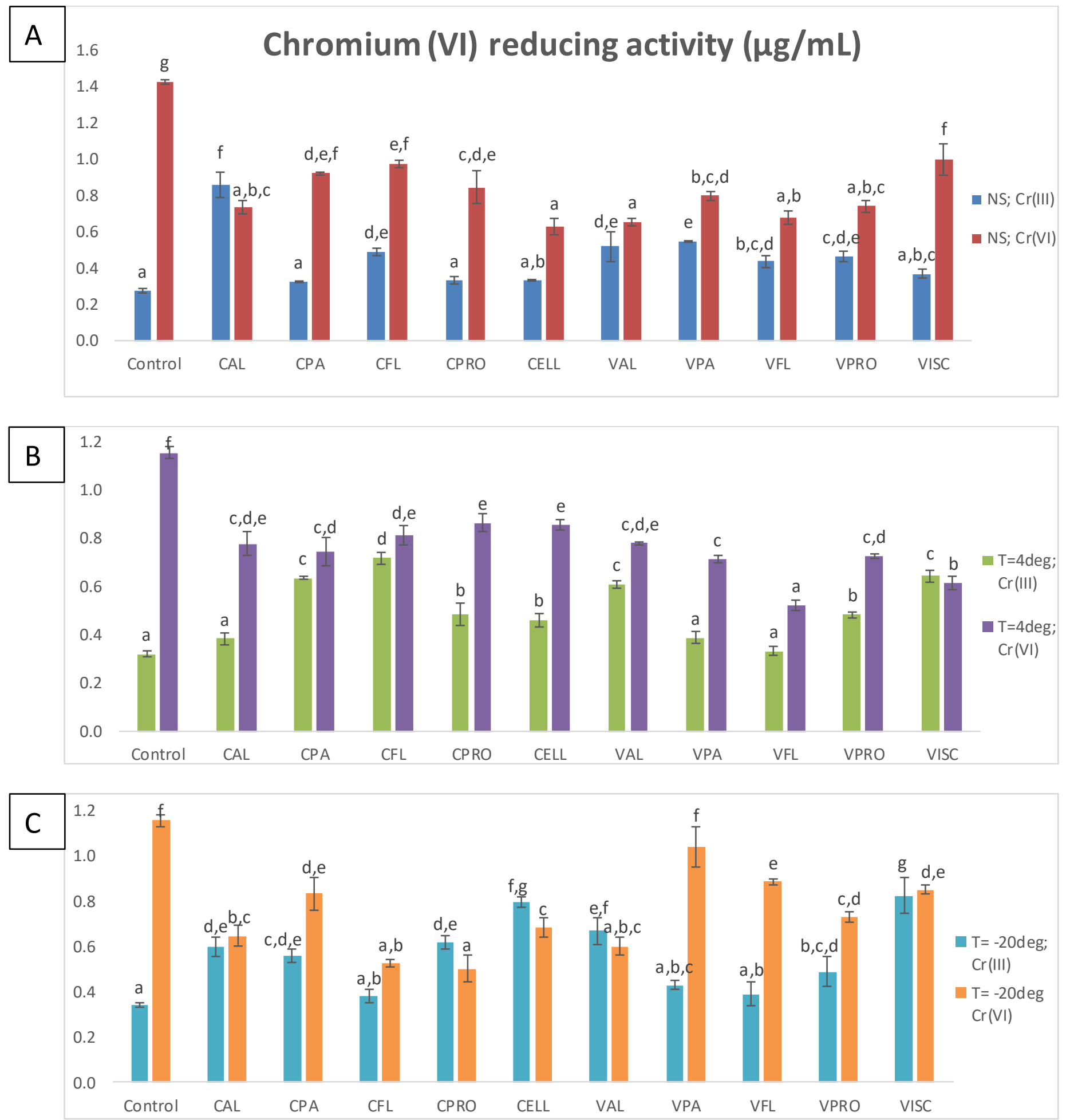

Figure 23: Activity of OBPI and OBPH samples to reduce he xavalent (Cr(VI)) to trivalent (Cr(III)) chromium. Each tre ated sample and control (untre ated) was analyzed in triplicates and expressed as mean \pm SEM. Each series indicate analysis with (A) no storage (NS), (B) storage at $4{ }^{\circ} \mathrm{C}$ for 24 hours and (C) storage at $-20{ }^{\circ} \mathrm{C}$ for $24 \mathrm{hrs}$. Different le tter above e ach bar indicate significant diffe rence within the same series as de te rmined with Turkey's Honest Significance Diffe re nces (HSD) in one-way ANOVA ( $p$ value $<0.05$ ). 


\section{Chapter 5 \\ Conclusions and Future Research}




\section{CONCLUSION}

This is the first study to determine the effect of peptides from oat bran on arsenic and chromium species in food. It was concluded that OBPIs and OBPHs had ORAC or peroxyl radical and hydroxyl radical scavenging activity that was significantly higher than GSH (control) and the result correlated with the level of thiols observed in OBPIs and OBPHs. OBPIs and OBPHs had Superoxide scavenging activity as well as the ability to inhibit lipid peroxidation in food, with higher inhibition observed at $20{ }^{0} \mathrm{C}$. In addition to their antioxidant activities, OBPIs and OBPHs also exhibited arsenic binding properties as well as reduced concentration of $\mathrm{Cr}(\mathrm{VI})$. We concluded that increase in concentrations of As (III) in treated samples might be due to its affinity for binding to proteins or peptides present in OBPI and OBPH. We also found that oxygen radicals generated during possible reduction of $\mathrm{Cr}$ (VI) to $\mathrm{Cr}$ (III), will be scavenged by OBPI and OBPH.

We can also conclude from these investigations that the enzymes, viscozyme and cellulase, generated protein isolates that exhibited antioxidant properties. Also, enzyme hydrolyzed oat bran protein generated peptides that had more radical scavenging activities compared to non-hydrolyzed protein. Hence they can both be used in food industries to prevent lipid peroxidation and prevent oxidative rancidity in order to increase the shelf life and nutritional values of food. OBPIs and OBPHs can also be used in reducing toxicity of transition metals and the scavenging of metal-mediated free radicals. The use of OBPI and OBPH will result in the reduction of DNA damages and potential carcinogenesis. 


\section{Future study}

Studies such as hydrophobicity and amino acid sequencing could be done to better characterize the oat bran protein isolates and hydrolysates so that the antioxidant property of each OBPI and OBPH is better understood. Their ability to inhibit lipid peroxidation in meat products over a longer period of time could be investigated as well in order to determine the improvement in food product shelf life. Further studies on the effect of OBPI and OBPH on the methylated species of arsenic can be done, as they are toxic forms of arsenic. Other species of chromium in food samples can be measured when reacted with hydrolyzed proteins. Also, further studies can be done to investigate metal-chelating properties of the OBPIs and OBPHs. 


\section{Chapter 6 \\ References and Bibliography}




\section{REFERENCES}

Ahmed, S., Gul, S., Gul, H., Bangash, M. H., Nuclear, C., \& Plant, P. (2013). Anti-Inflammatory and Anti-Platelet Activities of Avena Sativa Are Mediated Through the Inhibition of Cyclooxygenase and Lipoxygenase Enzymes, 1(2), 62-65.

Aiyar, J., Berkovits, H. J., Floyd, R. A., \& Wetterhahn, K. E. (1991). Reaction of Chromium ( VI ) with Glutathione or with Hydrogen Peroxide: Identification of Reactive Intermediates and Their Role in Chromium ( VI ) -Induced DNA Damage. Environmental Health, 92(Vi), 53-62. Retrieved from https:/www.ncbi.nlm.nih.gov/pmc/articles/PMC1519390/

Alrahmany, R., Avis, T. J., \& Tsopmo, A. (2013). Treatment of oat bran with carbohydrases increases soluble phenolic acid content and influences antioxidant and antimicrobial activities. Food Research International, 52(2), 568-574. http://doi.org/10.1016/j. foodres.2013.03.037

Alrahmany, R., \& Tsopmo, A. (2012a). Role of carbohydrases on the release of reducing sugar, total phenolics and on antioxidant properties of oat bran. Food Chemistry, 132(1), 413-418. http://doi.org/10.1016/j. foodchem.2011.11.014

Alrahmany, R., \& Tsopmo, A. (2012b). Role of carbohydrases on the release of reducing sugar, total phenolics and on antioxidant properties of oat bran. Food Chemistry, 132, 413-418. http://doi.org/10.1016/j. foodchem.2011.11.014

Aluko, R. (2012). Bioactive Peptides (pp. 37-61). http://doi.org/10.1007/978-1-4614-3480-1_3

Anderson, O. D. (2014). The spectrum of major seed storage genes and proteins in oats (Avena sativa). PLoS ONE, 9(7). http//doi.org/10.1371/journal.pone.0083569

Anderson, R. A. (1986). Chromium metabolism and its role in disease processes in man. Clinical Physiology and Biochemistry, 4(1), 31-41. Retrieved from http://www.ncbi.nlm.nih.gov/pubmed/3514054 
Andersson, A., Lindgren, A., \& Hultberg, B. (1995). Effect of thiol oxidation and thiol export from erythrocytes on determination of redox status of homocysteine and other thiols in plasma from healthy subjects and. Clinical Chemistry. Retrieved from http://clinchem.aaccjnls.org/content/41/3/361.short

Aposhian, H. V., \& Aposhian, M. M. (2006). Arsenic toxicology: Five questions. Chemical Research in Toxicology, 19(1), 1-15. http://doi.org/10.1021/tx050106d

Aruoma, O. (1998). Free radicals, oxidative stress, and antioxidants in human health and disease. Journal of the American Oil Chemists' Society, 75(2), 199-212. http://doi.org/10.1007/s11746998-0032-9

Baakdah, M. M., \& Tsopmo, A. (2016). Identification of peptides, metal binding and lipid peroxidation activities of HPLC fractions of hydrolyzed oat bran proteins. Journal of Food Science and Technology, 53(9), 3593-3601. http://doi.org/10.1007/s13197-016-2341-6

Bagchi, D., Hassoun, E. A., Bagchi, M., Muldoon, D. F., \& Stohs, S. J. (1995). Oxidative stress induced by chronic administration of sodium dichromate $[\mathrm{Cr}(\mathrm{VI})]$ to rats. Comparative Biochemistry and Physiology Part C: Pharmacology, Toxicology and Endocrinology, 110(3), 281-287. http://doi.org/10.1016/0742-8413(94)00103-H

Bagchi, D., Stohs, S. J., Downs, B. W., Bagchi, M., \& Preuss, H. G. (2002). Cytotoxicity and oxidative mechanisms of different forms of chromium. Toxicology, 180, 5-22. Retrieved from www.elsevier.com/locate/toxicol

Baky, H. H. A. El, \& El-Baroty, G. S. (2013). Healthy Benefit of Microalgal Bioactive Substances. Journal of Aquatic Science, 1(1), 11-22. http:/doi.org/10.12691/jas-1-1-3

Baran, C., Zeigler, M., \& Tridandapani, S. (2004). The role of ROS and RNS in regulating life and death of blood monocytes. Current. Retrieved from http://www.ingentaconnect.com/content/ben/cpd/2004/00000010/00000008/art00005 
Bates, L. F., \& Baqi, A. (2015). The magnetic properties of chromium. Proceedings of the Physical Society, 48(5), 781-794. http://doi.org/10.1088/0959-5309/48/5/311

Beckman, J., \& Koppenol, W. (1996). Nitric oxide, superoxide, and peroxynitrite: the good, the bad, and ugly. American Journal of Physiology. Retrieved from http:/ajpcell.physiology.org/content/ajpcel1/271/5/C1424.full.pdf

Beyersmann, D., \& Hartwig, A. (2008). Carcinogenic metal compounds: Recent insight into molecular and cellular mechanisms. Archives of Toxicology, 82(8), 493-512. http://oi.org/10.1007/s00204-008-0313-y

Bhattacharya, M., Jain, N., Bhasne, K., Kumari, V., \& Mukhopadhyay, S. (2011). pH-Induced conformational isomerization of bovine serum albumin studied by extrinsic and intrinsic protein fluorescence. In Journal of Fluorescence (Vol. 21, pp. 1083-1090). http://oi.org/10.1007/s10895-010-0781-3

Bonde, J., \& Christensen, J. (1991). Chromium in biological samples from low-level exposed stainless steel and mild steel welders. Archives of Environmental Health: An. Retrieved from http:/www.tand fonline.com/doi/abs/10.1080/00039896.1991.9937453

Breitenbach, M., \& Eckl, P. (2015). Introduction to oxidative stress in biomedical and biological research. Biomolecules, 5(2), 1169-1177. http://doi.org/10.3390/biom5021169

Brinegar, A. C., \& Peterson, D. M. (1982a). Separation and characterization of oat globulin polypeptides. Archives of Biochemistry and Biophysics, 219(1), 71-79. http://oi.org/10.1016/0003-9861(82)90135-7

Brinegar, A. C., \& Peterson, D. M. (1982b). Separation and characterization of oat globulin polypeptides. Archives of Biochemistry and Biophysics, 219(1), 71-79. http://doi.org/10.1016/0003-9861(82)90135-7

Burgess, S. R., \& Shewry, P. R. (1986). Identification of Homologous Globulins from Embryos of 
Wheat, Barley, Rye and Oats. Journal of Experimental Botany, 37(185), 1863-1871.

Butt, M. S. M. S., Tahir-Nadeem, M., Khan, M. K. I., Shabir, R., \& Butt, M. S. M. S. (2008). Oat: Unique among the cereals. European Journal of Nutrition, 47(2), 68-79. http://doi.org/10.1007/s00394-008-0698-7

Cao, G., \& Prior, R. (1999). Measurement of oxygen radical absorbance capacity in biological samples. Methods in Enzymology. Retrieved from http://www.sciencedirect.com/science/article/pii/S0076687999990080

Carlisle, D. L., Pritchard, D. E., Singh, J., Owens, B. M., Blankenship, L. J., Orenstein, J. M., \& Patierno, S. R. (2000). Apoptosis and P53 Induction in Human Lung Fibroblasts Exposed to Chromium (VI): Effect of Ascorbate and Tocopherol. Toxicological Sciences, 55(1), 60-68. http://doi.org/10.1093/toxsci/55.1.60

Carr, A., Zhu, B., \& Frei, B. (2000). Potential antiatherogenic mechanisms of ascorbate (vitamin C) and $\alpha$-tocopherol (vitamin E). Circulation Research. Retrieved from http:/circres.ahajournals.org/content/87/5/349.short

Chakrabarti, S., Jahandideh, F., \& Wu, J. (2014). Food-derived bioactive peptides on inflammation and oxidative stress. Biomed Res Int, 2014.

Chan, K., \& Wasserman, B. (1993). Direct colorimetric assay of free thiol groups and disulfide bonds in suspensions of solubilized and particulate cereal proteins. Cereal Chemistry.

Chen, C., Milbury, P., Kwak, H., \& Collins, F. (2004). Avenanthramides and phenolic acids from oats are bioavailable and act synergistically with vitamin $\mathrm{C}$ to enhance hamster and human LDL resistance to oxidation. The Journal of Nutrition. Retrieved from http://jn. nutrition.org/content/134/6/1459.short

Chen, H., Muramoto, K., \& Yamauchi, F. (1995). Structural analysis of antioxidative peptides from Soybean. beta.-Conglycinin. Journal of Agricultural and. Retrieved from 
http:/pubs.acs.org/doi/pdf/10.1021/jf00051a004

Chen, H., Muramoto, K., Yamauchi, F., Fujimoto, K., \& Nokihara, K. (1998). Antioxidative Properties of Histidine-Containing Peptides Designed from Peptide Fragments Found in the Digests of a Soybean Protein. Journal of Agricultural and Food Chemistry, 46(1), 49-53. http:/doi.org/Doi 10.1021/J970649w

Claver, I., \& Zhou, H. (2005). Enzymatic hydrolysis of defatted wheat germ by proteases and the effect on the functional properties of resulting protein hydrolysates. Journal of Food Biochemistry. Retrieved from http://onlinelibrary.wiley.com/doi/10.1111/j.17454514.2005.00004.x/full

Codd, R., Dillon, C. T., Levina, A., \& Lay, P. A. (2001). Studies on the genotoxicity of chromium: from the test tube to the cell. Coordination Chemistry Reviews, 216217, 537-582. Retrieved from http:/ac.els-cdn.com.proxy.library.carleton.ca/S0010854500004082/1-s2.0S0010854500004082-main.pdf?_tid=3578 f206-6673-11e7-b43500000aab0f01\&acdnat=1499803246_377c2167121551dba44a8fe265dab23c

Cohen, M. D., Kargacin, B., Klein, C. B., \& Costa, M. (1993). Mechanisms of Chromium Carcinogenicity and Toxicity. Critical Reviews in Toxicology, 23(3), 255-281. http://oi.org/10.3109/10408449309105012

Cohen, S., Ohnishi, T., Arnold, L., \& Le, X. (2007). Arsenic-induced bladder cancer in an animal model. Toxicology and Applied. Retrieved from http:/www.sciencedirect.com/science/article/pii/S0041008X06003711

Collins, F. W., Mclachlan, D. C., \& Blackwell, B. A. (1991). Avenalumic Acids-BY COLLINS. Cereal Chemistry, 68(2), 184-189. Retrieved from http:/www.aaccnet.org/publications/cc/backissues/1991/Documents/68_184.pdf

Dabeka, R., McKenzie, A., \& Lacroix, G. (1993). Survey of arsenic in total diet food composites 
and estimation of the dietary intake of arsenic by Canadian adults and children. Journal of AOAC. Retrieved from http:/europepmc.org/abstract/med/8448438

Dalle-Donne, I., Aldini, G., Carini, M., Colombo, R., Rossi, R., \& Milzani, A. (2006). Protein carbonylation, cellular dysfunction, and disease progression. Journal of Cellular and Molecular Medicine, 10(2), 389-406. http://oi.org/10.1111/j.1582-4934.2006.tb00407.x

Daou, C., \& Zhang, H. (2012). Oat Beta-Glucan: Its Role in Health Promotion and Prevention of Diseases. Reviews in Food Science and Food Safety. Retrieved from http:/onlinelibrary.wiley.com/doi/10.1111/j.1541-4337.2012.00189.x/full

Davalos, A., Miguel, M., \& Bartolome, B. (2004). Antioxidant activity of peptides derived from egg white proteins by enzymatic hydrolysis. Journal of Food. Retrieved from http://jfoodprotection.org/doi/abs/10.4315/0362-028X-67.9.1939

Davies, C., \& Tournier, C. (2012). Exploring the function of the JNK (c-Jun N-terminal kinase) signalling pathway in physiological and pathological processes to design novel therapeutic strategies. Biochemical Society Transactions, 40(1), 85-89. http://doi.org/10.1042/BST20110641

Day, J., Montes-Bayón, M., \& Vonderheide, A. (2002). A study of method robustness for arsenic speciation in drinking water samples by anion exchange HPLC-ICP-MS. Analytical and. Retrieved from http://www.springerlink.com/index/QDDGYEE86XD32VLY.pdf

Decker, E. A., Rose, D. J., \& Stewart, D. (2014). Processing of oats and the impact of processing operations on nutrition and health benefits. British Journal of Nutrition, 112(S2), S58-S64. http://oi.org/10.1017/S000711451400227X

Dimberg, L. H., Gissén, C., \& Nilsson, J. (2005). Phenolic Compounds in Oat Grains (Avena sativa L.) Grown in Conventional and Organic Systems. AMBIO: A Journal of the Human Environment, 34(4), 331-337. http://doi.org/10.1579/0044-7447-34.4.331 
Ding, W., Hudson, L., \& Liu, K. (2005). Inorganic arsenic compounds cause oxidative damage to DNA and protein by inducing ROS and RNS generation in human keratinocytes. Molecular and Cellular Biochemistry. Retrieved from http $/ /$ www.springerlink.com/index/F6648HV2657U3155.pdf

Doucet, D., Otter, D. E., Gauthier, S. F., \& Foegeding, E. A. (2003). Enzyme-induced gelation of extensively hydrolyzed whey proteins by alcalase: Peptide identification and determination of enzyme specificity. Journal of Agricultural and Food Chemistry, 51(21), 6300-6308. http://oi.org/10.1021/jf026242v

Eftink, M. R. (2002). Intrinsic Fluorescence of Proteins. In Topics in Fluorescence Spectroscopy (pp. 1-15). Boston: Kluwer Academic Publishers. http://doiorg/10.1007/0-306-47102-7_1

Ekholm, P., Virkki, L., Ylinen, M., \& Johansson, L. (2003). The effect of phytic acid and some natural chelating agents on the solubility of mineral elements in oat bran. Food Chemistry, 80(2), 165-170. http://doi.org/10.1016/S0308-8146(02)00249-2

Ellman, G. L. (1959). Tissue sulfhydryl groups. In Archives of Biochemistry and Biophysics (Vol. 82, pp. 70-77). http://doi.org/10.1016/0003-9861(59)90090-6

Faita, F., Cori, L., Bianchi, F., \& Andreassi, M. G. (2013). Arsenic-induced genotoxicity and genetic susceptibility to arsenic-related pathologies. International Journal of Environmental Research and Public Health, 10(4), 1527-1546. http//doi.org/10.3390/ijerph10041527

Fang, Y., Yang, S., \& Wu, G. (2015). Free Radicals, Antioxidants, and Nutrition. Nutrition, (June), 2-10. http://doi.org/10.13140/RG.2.1.4515.0886

Fang, Z., Zhao, M., Zhen, H., Chen, L., Shi, P., \& Huang, Z. (2014). Genotoxicity of tri- and hexavalent chromium compounds in vivo and their modes of action on DNA damage in vitro. PLoS ONE, 9(8). http://doi.org/10.1371/journal.pone.0103194

Fawell, J. K., \& Lund, U. (1996). Chromium in Drinking-water. Health Criteria and Other 
Supporting Information, World Health Organization, 2, 1-13. Retrieved from http:/www.who.int/water_sanitation_health/dwq/chemicals/chromium.pdf

Gao, Q., Smith, J. C., \& Tsopmo, A. (2014). Optimized Protamex Digested oat bran proteins: Antioxidant properties and identification of new peptides. Austin J. Nutri. Food Sci., 2(10), 1053.

Ghisaidoobe, A. B. T., \& Chung, S. J. (2014). Intrinsic tryptophan fluorescence in the detection and analysis of proteins: A focus on förster resonance energy transfer techniques. International Journal of Molecular Sciences, 15(12), 22518-22538. http://doi.org/10.3390/ijms151222518

Ghosh, P., Banerjee, M., Giri, A. K., \& Ray, K. (2008). Toxicogenomics of arsenic: Classical ideas and recent advances. Mutation Research - Reviews in Mutation Research, 659(3), 293-301. http://doi.org/10.1016/j.mrrev.2008.06.003

Goodwin, T. W., \& Morton, R. A. (1946). The spectrophotometric determination of tyrosine and tryptophan in proteins. Biochem $J, 40(5-6), 628-632$. Retrieved from http:/www.ncbi.nlm.nih.gov/pubmed/16748065

Guan, X., Yao, H., Chen, Z., Shan, L., \& Zhang, M. (2006). Some functional properties of oat bran protein concentrate modified by trypsin. Food Chemistry, 101(1), 163-170. http:/doi.org/10.1016/j. foodchem.2006.01.011

Halliwell, B., \& Gutteridge, J. (2015). Free radicals in biology and medicine. Retrieved from https:/books. google.ca/books?hl=en\&lr=\&id=3DlKCgAAQBAJ\&oi=fnd\&pg=PP1\&dq=Free + Radicals + in + Biology+and + Medicine\&ots=bnqH4VBplY\&sig=Q4VZkm3SGqjMCucuy2jslJF BVlk

Health Canada. (2008). Chromium. Retrieved from https://www.canada.ca/content/dam/canada/health-canada/migration/healthycanadians/publications/healthy-living-vie-saine/water-chromium-chrome-eau/alt/water- 
chromium-chrome-eau-eng.pdf

Hei, T. K., Liu, S. X., \& Waldren, C. (1998). Mutagenicity of arsenic in mammalian cells: Role of reactive oxygen species. Cell Biology, 95, 8103-8107. Retrieved from http://www.pnas.org/content/95/14/8103.full.pdf

Henkler, F., Brinkmann, J., \& Luch, A. (2010). The role of oxidative stress in carcinogenesis induced by metals and xenobiotics. Cancers, 2(2), 376-396. http://oi.org/10.3390/cancers2020376

Höhn, A., König, J., \& Grune, T. (2013). Protein oxidation in aging and the removal of oxidized proteins. Journal of Proteomics, 92, 132-159. http//doi.org/10.1016/j.jprot.2013.01.004

Hossain, E., Ota, A., Takahashi, M., Karnan, S., Damdindorj, L., Konishi, Y., ... Hosokawa, Y. (2013). Arsenic upregulates the expression of angiotensin II Type I receptor in mouse aortic endothelial cells. Toxicology Letters, 220(1), 70-75. http://doi.org/10.1016/j.toxlet.2013.04.006

Hou, H., Li, B., Zhao, X., Zhang, Z., \& Li, P. (2011). Optimization of enzymatic hydrolysis of Alaska pollock frame for preparing protein hydrolysates with low-bitterness. LWT-Food Science and Technology. Retrieved from http:/www.sciencedirect.com/science/article/pii/S0023643810003117

Huang, D., Ou, B., Hampsch-Woodill, M., Flanagan, J. A., \& Prior, R. L. (2002). High-throughput assay of oxygen radical absorbance capacity (ORAC) using a multichannel liquid handling system coupled with a microplate fluorescence reader in 96-well format. Journal of Agricultural and Food Chemistry, 50(16), 4437-4444. http///doi.org/10.1021/jf0201529

Hughes, M. F., Beck, B. D., Chen, Y., Lewis, A. S., \& Thomas, D. J. (2011a). Arsenic exposure and toxicology: A historical perspective. Toxicological Sciences, 123(2), 305-332. http://oi.org/10.1093/toxsci/kfr184 
Hughes, M. F., Beck, B. D., Chen, Y., Lewis, A. S., \& Thomas, D. J. (2011b). Arsenic exposure and toxicology: A historical perspective. Toxicological Sciences, 123(2), 305-332. http://doi.org/10.1093/toxsci/kfr184

Hulle, M. Van, Zhang, C., Zhang, X., \& Cornelis, R. (2002). Arsenic speciation in chinese seaweeds using HPLC-ICP-MS and HPLC-ES-MS. Analyst. Retrieved from http://pubs.rsc.org/en/content/articlehtml/2002/an/b110940e

IARC, I. A. for R. on C. (1987). IARC Monographs on the Evaluation of Carcinogenic Risks to Humans. Overall Evaluations of Carcinogenicity: An Updating of IARC Monographs Volumes 1 to 42 . Retrieved from http://bases.bireme.br/cgibin/wxislind.exe/iah/online/? IsisScript $=\mathrm{iah} / \mathrm{iah} . \mathrm{xis} \& \mathrm{src}=$ google \&base=WHOLIS\&lang=p\&nex tAction $=\operatorname{lnk} \&$ exprSearch $=9283214110$ \&indexSearch $=$ ID

Jannuzi, B., \& Dey, A. (1999). The NOAO Deep Wide-Field Survey. Photometric Redshifts and the Detection of. Retrieved from http://adsabs.harvard.edu/full/1999ASPC..191..111J

Je, J.-Y., Park, P.-J., Kim, E.-K., Park, J.-S., Yoon, H.-D., Kim, K.-R., \& Ahn, C.-B. (2009). Antioxidant activity of enzymatic extracts from the brown seaweed Undaria pinnatifida by electron spin resonance spectroscopy. LWT - Food Science and Technology, 42(4), 874-878. http://doi.org/10.1016/j.lwt.2008.10.012

Jodayree, S., Smith, J. C., \& Tsopmo, A. (2012). Use of carbohydrase to enhance protein extraction efficiency and antioxidative properties of oat bran protein hydrolysates. Food Research International, 46(1), 69-75. http://doi.org/10.1016/j.foodres.2011.12.004

Jomova, K., Jenisova, Z., Feszterova, M., Baros, S., Liska, J., Hudecova, D., ... Valko, M. (2011). Arsenic: Toxicity, oxidative stress and human disease. Journal of Applied Toxicology, 31(2), 95-107. http://doi.org/10.1002/jat.1649

Jomova, K., \& Valko, M. (2011). Advances in metal-induced oxidative stress and human disease. 
Toxicology, 283(2-3), 65-87. http://doi.org/10.1016/j.tox.2011.03.001

K. Shah, R. G. Kumar, S. Verma, and R. S. D. (2001). Effect of cadmium on lipid peroxidation, superoxide anion gener- ation and activities of antioxidant enzymes in growing rice seedlings. Plant Science, 161, 1135-1144. Retrieved from www.elsevier.com/locate/plantsci

Kakkar, P., \& Jaffery, F. N. (2005). Biological markers for metal toxicity. Environmental Toxicology and Pharmacology, 19, 335-349. http://doi.org/10.1016/j.etap.2004.09.003

Karagas, M., Morris, J., Weiss, J., \& Spate, V. (1996). Toenail samples as an indicator of drinking water arsenic exposure. Cancer Epidemiology. Retrieved from http://cebp.aacrjournals.org/content/5/10/849.short

Karagas, M., Stukel, T., \& Tosteson, T. (2002). Assessment of cancer risk and environmental levels of arsenic in New Hampshire. International Journal of Hygiene and. Retrieved from http:/www.sciencedirect.com/science/article/pii/S1438463904701315

Kent, N. L. (Norman L., \& Evers, A. D. (1994). Technology of cereals : an introduction for students offood science and agriculture. Retrieved from https:/books. google.ca/books?hl=en\&lr=\&id=JvaiAgAAQBAJ\&oi=fnd\&pg=PP1\&dq=cereals + consumption + canada + and + USA\&ots $=$ Fkul8rDnob\&sig $=$ LLofl fTX9 $\times 6 \mathrm{hmcsrnDmLRm94t0}$ $\mathrm{U}$

Khang, D. T., Vasiljevic, T., \& Xuan, T. D. (2016). Bioactive compounds , antioxidant and enzyme activities in germination of oats ( Avena sativa L .). International Food Research Journal, 23(5), 1980-1987. Retrieved from http $/ /$ www.ifrj.upm.edu.my/23 (05) 2016/(20).pdf

Kim, E., Lee, S., Lim, B., Jeon, Y., \& Song, M. (2008). Antioxidative and neuroprotective effects of enzymatic extracts from leaves of Perilla frutescens var. japonica. Food Science and. Retrieved from http://www.dbpia.co.kr/Journal/ArticleDetail/NODE01729549

Kirk, S., \& Sawyer, R. (1991). Pearson's composition and analysis of foods. Retrieved from 
https://www.cabdirect.org/cabdirect/abstract/19931459518

Kitchin, K. T., \& Ahmad, S. (2003). Oxidative stress as a possible mode of action for arsenic carcinogenesis. Toxicology Letters, 137(1-2), 3-13. http://oi.org/10.1016/S03784274(02)00376-4

Kitchin, K. T., \& Conolly, R. (2010). Arsenic-induced carcinogenesissoxidative stress as a possible mode of action and future research needs for more biologically based risk assessment. Chemical Research in Toxicology. http://doi.org/10.1021/tx900343d

Kitchin, K. T., \& Wallace, K. (2008). The role of protein binding of trivalent arsenicals in arsenic carcinogenesis and toxicity. Journal of Inorganic Biochemistry, 102(3), 532-539. http://doi.org/10.1016/j.jinorgbio.2007.10.021

Klose, C., \& Arendt, E. K. (2012). Proteins in Oats; their Synthesis and Changes during Germination: A Review. Critical Reviews in Food Science and Nutrition, 52(7), 629-639. http://doi.org/10.1080/10408398.2010.504902

Kodama, T., Miyazaki, T., Kitamura, I., \& Suzuki, Y. (2005). Effects of single and long-term administration of wheat albumin on blood glucose control: randomized controlled clinical trials. European Journal of. Retrieved from http:/www.nature.com/ejcn/journal/v59/n3/abs/1602085a.html

Koehler, P., \& Wieser, H. (2013). Chemistry of cereal grains. In Handbook on Sourdough Biotechnology (pp. 245-264). http://doi.org/10.1007/978-1-4614-5425-0

Koons, R., \& Peters, C. (1994). Axial distribution of arsenic in individual human hairs by solid sampling graphite furnace AAS. Journal of Analytical Toxicology. Retrieved from https://academic.oup.com/jat/article-abstract/18/1/36/813749

Korhonen, H., \& Pihlanto, A. (2003). Food-derived Bioactive Peptides - Opportunities for Designing Future Foods. Current Pharmaceutical Design, 9(16), 1297-1308. 
http://oi.org/10.2174/1381612033454892

Kortenkamp, A. (1997). Problems in the biological monitoring of chromium (VI) exposed individuals. Biomarkers. Retrieved from http:/www.tand fonline.com/doi/abs/10.1080/135475097231788

Kotyzova, D., Hodkova, A., Bludovska, M., \& Eybl, V. (2013). Effect of chromium ( VI ) exposure on antioxidant defense status and trace element homeostasis in acute experiment in rat. Toxicology and Industrial Health, in press, 1-7. http://oi.org/10.1177/0748233713487244

Laemmli, U. K. (1970). Cleavage of structural proteins during the assembly of the head of bacteriophage T4. Nature, 227(5259), 680-685. http://doi.org/10.1038/227680a0

Léonard, A., \& Lauwerys, R. R. (1980). Carcinogenicity and mutagenicity of chromium. Mutation Research, 76(3), 227-239. http://doi.org/10.1016/0165-1110(80)90018-4

Leonard, S. S., Harris, G. K., \& Shi, X. (2004). Metal-induced oxidative stress and signal transduction. Free Radical Biology and Medicine, 37(12), 1921-1942. http://doi.org/10.1016/j. freeradbiomed.2004.09.010

Li, D., Morimoto, K., Takeshita, T., \& Lu, Y. (2001). Arsenic induces DNA damage via reactive oxygen species in human cells. Environmental Health and Preventive Medicine, 6(1), 27-32. http://doi.org/10.1007/BF02897306

Li, H.-M. M., HU, X., GUO, P., FU, P., XU, L., \& ZHANG, X.-Z. Z. (2010). Antioxidant properties and possible mode of action of corn protein peptides and zein peptides. Journal of Food Biochemistry, 34(SUPPL. 1), 44-60. http//doi.org/10.1111/j.1745-4514.2009.00292.x

Li, Y., Jiang, B., Zhang, T., Mu, W., \& Liu, J. (2008). Antioxidant and free radical-scavenging activities of chickpea protein hydrolysate (CPH). Food Chemistry. Retrieved from http://www.sciencedirect.com/science/article/pii/S0308814607004207

Liu, J., Guan, X., Zhu, D., \& Sun, J. (2008). Optimization of the enzymatic pretreatment in oat bran 
protein extraction by particle swarm optimization algorithms for response surface modeling. LWT - Food Science and Technology, 41(10), 1913-1918. http://doi.org/10.1016/j.lwt.2008.02.013

Liu, R. H. (2013). Dietary bioactive compounds and their health implications. Journal of Food Science, 78(SUPPL.1). http://doi.org/10.1111/1750-3841.12101

Liu, S., \& Dixon, K. (1996). Induction of mutagenic DNA damage by chromium (VI) and glutathione. Environmental and Molecular Mutagenesis. Retrieved from http//onlinelibrary.wiley.com/doi/10.1002/(SICI)1098-2280(1996)28:2\%3C71::AIDEM2\%3E3.0.CO;2-H/full

Lobo, V., Patil, A., Phatak, A., \& Chandra, N. (2010). Free radicals, antioxidants and functional foods: Impact on human health. Pharmacognosy Reviews, 4(8), 118-26. http://doi.org/10.4103/0973-7847.70902

Lou, J., Jin, L., Wu, N., Tan, Y., Song, Y., Gao, M., ... He, J. (2013). DNA damage and oxidative stress in human B lymphoblastoid cells after combined exposure to hexavalent chromium and nickel compounds. FOOD AND CHEMICAL TOXICOLOGY, 55, 533-540. http://oi.org/10.1016/j.fct.2013.01.053

Luczak, M. W., Green, S. E., \& Zhitkovich, A. (2015). Different ATM Signaling in Response to Chromium(VI) Metabolism via Ascorbate and Nonascorbate Reduction: Implications for in Vitro Models and Toxicogenomics. Environmental Health Perspectives, 124(1), 61-61. http://oi.org/10.1289/ehp.1409434

Ma, C.-Y. (1985). Functional Properties of Oat Concentrate Treated with Linoleate or Trypsin. Canadian Institute of Food Science and Technology Journal, 18(1), 79-84. http://doi.org/10.1016/S0315-5463(85)71724-5

Markwell, M. A. K., Haas, S. M., Bieber, L. L., \& Tolbert, N. E. (1978). A modification of the 
Lowry procedure to simplify protein determination in membrane and lipoprotein samples. Analytical Biochemistry, 87(1), 206-210. http://doi.org/10.1016/0003-2697(78)90586-9

Martinez-monteagudo, S. I. (2016). Oxidative Stability of Fats and Oils Measured by Differential Scanning Calorimetry for Food and Industrial Applications Oxidative Stability of Fats and Oils Measured by Differential Scanning Calorimetry for Food and Industrial Applications, (June). http://oi.org/10.5772/54486

Matsui, M., Nishigori, C., Toyokuni, S., Takada, J., Akaboshi, M., Ishikawa, M., ... Miyachi, Y. (1999). The Role of Oxidative DNA Damage in Human Arsenic Carcinogenesis: Detection of 8-Hydroxy-2J-Deoxyguanosine in Arsenic-Related Bowen's Disease. Journal of Investigative Dermatology, 113, 26-31. http://oi.org/10.1046/j.1523-1747.1999.00630.x

McGrew, D., \& Chambers, E. (2012). Alcoholic Beverages. Alcoholic Beverages. http://doi.org/10.1533/9780857095176.1.24

Menzel, D. B., Hamadeh, H. K., Lee, E., Meacher, D. M., Said, V., Rasmussen, R. E., ... Roth, R. N. (1999). Arsenic binding proteins from human lymphoblastoid cells. Toxicology Letters, 105(2), 89-101. http://doi.org/10.1016/S0378-4274(98)00380-4

Merz, M., Eisele, T., Berends, P., Appel, D., Rabe, S., Blank, I., ... Fischer, L. (2015).

Flavourzyme, an Enzyme Preparation with Industrial Relevance: Automated Nine-Step Purification and Partial Characterization of Eight Enzymes. Journal of Agricultural and Food Chemistry, 63(23), 5682-5693. http://doi.org/10.1021/acs.jafc.5b01665

Mirsky, a E. (1936). Sulfhydryl and Disulfide Groups of Proteins : Iv. Sulfhydryl Groups of the Proteins of Muscle. The Journal of General Physiology, 19(4), 559-570. http:/doi.org/10.1085/jgp.19.4.559

Mizumura, A., Watanabe, T., Kobayashi, Y., \& Hirano, S. (2010). Identification of arsenite-and arsenic diglutathione-binding proteins in human hepatocarcinoma cells. Toxicology and 
Applied Pharmacology, 242(2), 119-125. http//doi.org/10.1016/j.taap.2009.10.013

Mohamed, A., Biresaw, G., Xu, J., Hojilla-Evangelista, M. P., \& Rayas-Duarte, P. (2009). Oats protein isolate: Thermal, rheological, surface and functional properties. Food Research International, 42(1), 107-114. http://oi.org/10.1016/j.foodres.2008.10.011

Muller, D. (1990). Antioxidant therapy in neurological disorders. Antioxidants in Therapy and Preventive Medicine. Retrieved from https://ink.springer.com/chapter/10.1007/978-1-4684$5730-8+73$

Mylonas, C., \& Kouretas, D. (1999). Lipid peroxidation and tissue damage. In Vivo. Retrieved from http:/www.ncbi.nlm.nih.gov/pubmed/10459507

Navas-Acien, A., Sharrett, A. R., Silbergeld, E. K., Schwartz, B. S., Nachman, K. E., Burke, T. A., \& Guallar, E. (2005). Arsenic exposure and cardiovascular disease: A systematic review of the epidemiologic evidence. American Journal of Epidemiology, 162(11), 1037-1049. http://doi.org/10.1093/aje/kwi330

Nnanna, I. A., \& Gupta, S. V. (1996). Purification and Partial Characterization of Oat Bran Globulin. Journal of Agricultural and Food Chemistry, 44(11), 3494-3499. http://doi.org/10.1021/j9960269v

Noori, S. (2012). An Overview of Oxidative Stress and Antioxidant Defensive System. Journal of Clinical \& Cellular Immunology, 1(8), 1177-1188. http//doi.org/10.4172/scientificreports.413

Nordenson, I., \& Beckman, L. (1991). Is the genotoxic effect of arsenic mediated by oxygen free radicals? Human Heredity. Retrieved from http:/www.karger.com/Article/Abstract/153979

Nourooz-Zadeh, J. (1998). Ferrous ion oxidation in presence of xylenol orange for detection of lipid hydroperoxides in plasma. Methods in Enzymology. http//doi.org/10.1016/S00766879(99)00113-5

Ou, K., Liu, Y., Zhang, L., Yang, X., Huang, Z., Nout, M. J. R., \& Liang, J. (2010). Effect of 
neutrase, alcalase, and papain hydrolysis of whey protein concentrates on iron uptake by Caco2 cells. Journal of Agricultural and Food Chemistry, 58(8), 4894-4900. http://oi.org/10.1021/jf100055y

Paschal, B., Obar, R., \& Vallee, R. (1989). Interaction of brain cytoplasmic dynein and MAP2 with a common sequence at the $\mathrm{C}$ terminus of tubulin. Nature. Retrieved from http:/link.springer.com/article/10.1038/342569a0

Pavithra, K., \& Vadivukkarasi, S. (2015). Evaluation of free radical scavenging activity of various extracts of leaves from Kedrostis foetidissima (Jacq.) Cogn. Food Science and Human Wellness, 4(1), 42-46. http://doi.org/10.1016/j.fshw.2015.02.001

Pérez-González, A., Alvarez-Idaboy, J. R., \& Galano, A. (2015). Free-radical scavenging by tryptophan and its metabolites through electron transfer based processes. Journal of Molecular Modeling, 21(8), 213. http://doi.org/10.1007/s00894-015-2758-2

Persson, L. (2002). The Bangladesh arsenic calamity and reproduction: does arsenic contamination of drinking water result in fetal wastage, intrauterine growth retardation,. Retrieved from http:/dspace.icddrb.org/jspui/bitstream/123456789/5039/1/ICDDRBProtocol-2002-029.pdf

Pihlanto, A. (2006). Antioxidative peptides derived from milk proteins. International Dairy Journal, 16(11), 1306-1314. http:/doi.org/10.1016/j. idairyj.2006.06.005

Poljšak, B., Gazdag, Z., Jenko-Brinovec, Š., Fujs, Š., Pesti, M., Bélagyi, J., ... Raspor, P. (2005). Pro-oxidative vs antioxidative properties of ascorbic acid in chromium(VI)-induced damage: An in vivo and in vitro approach. Journal of Applied Toxicology, 25(6), 535-548. http://doi.org/10.1002/jat.1093

Prakash, M., Shetty, M. S., Tilak, P., \& Anwar, N. (2009). Total Thiols: Biomedical importance and their alteration in various disorders. Online Journal of Health and Allied Sciences. Retrieved from http:/www.ojhas.org/issue30/2009-2-2.htm 
Rahman, T., Hosen, I., Islam, M. M. T., \& Shekhar, H. U. (2012). Oxidative stress and human health. Advances in Bioscience and Biotechnology, 3, 997-1019. http://doi.org/10.4236/abb.2012.327123

Rice-evans, C., Miller, N., \& Bolwell, P. (1995). The relative antioxidant activities of plant-derived polyphenolic flavonoids. Free Radical. Retrieved from http:/www.tand fonline.com/doi/abs/10.3109/10715769509145649

Rosset, M., Acquaro, V. R., \& Beléia, A. D. P. (2014). Protein Extraction from Defatted Soybean Flour with Viscozyme L Pretreatment. Journal of Food Processing and Preservation, 38(3), 784-790. http://doi.org/10.1111/jfpp.12030

Ryan, L., Thondre, P. S., \& Henry, C. J. K. (2011). Oat-based breakfast cereals are a rich source of polyphenols and high in antioxidant potential. Journal of Food Composition and Analysis, 24(7), 929-934. http://doi.org/10.1016/j.jfca.2011.02.002

Sarmadi, B. H., \& Ismail, A. (2010). Antioxidative peptides from food proteins: A review. Peptides, 31, 1949-1956. http://doi.org/10.1016/j.peptides.2010.06.020

Sazakli, E., Villanueva, C. M., Kogevinas, M., Maltezis, K., Mouzaki, A., \& Leotsinidis, M. (2014). Chromium in drinking water: association with biomarkers of exposure and effect. International Journal of Environmental Research and Public Health, 11(10), 10125-45. http://doi.org/10.3390/ijerph1 11010125

Schoen, A., Beck, B., Sharma, R., \& Dubé, E. (2004). Arsenic toxicity at low doses: epidemiological and mode of action considerations. Toxicology and Applied. Retrieved from http://www.sciencedirect.com/science/article/pii/S0041008X04000717

Sedlak, J., \& Lindsay, R. H. (1968). Estimation of Total, Protein-Bound, and Nonprotein Sulfhydryl Groups in Tissue with Ellman's Reagent. ANALYTICAL BIOCHEMISTRY, 25, 192-205. Retrieved from http://www.sciencedirect.com/sdfe/pdf/download/eid/1-s2.0- 
0003269768900924/first-page-pdf

Sheih, I. C., Fang, T. J., Wu, T. K., \& Lin, P. H. (2010). Anticancer and antioxidant activities of the peptide fraction from algae protein waste. Journal of Agricultural and Food Chemistry, 58(2), 1202-1207. http $/ /$ doi.org/10.1021/jf903089m

Shi, X. (1999). REDUCTION OF CHROMIUM (VI) AND ITS RELATIONSHIP TO

CARCINOGENESIS. Journal of Toxicology and Environmental Health, Part BOnline)

Journal Xianglin Shi Journal of Toxicology and Environmental Health, Part B, 2(1), 1093-

7404. http://doi.org/10.1080/109374099281241

Shi, X., \& Dalal, N. (1994). Generation of hydroxyl radical by chromate in biologically relevant systems: role of $\mathrm{Cr}(\mathrm{V})$ complexes versus tetraperoxochromate (V). Environmental Health Perspectives. Retrieved from https:/www.ncbi.nlm.nih.gov/pmc/articles/PMC1567404/

Shi, X., \& Dalal, N. S. (1989). Chromium (V) and hydroxyl radical formation during the glutathione reductase-catalyzed reduction of chromium (VI). Biochemical and Biophysical Research Communications. http://doi.org/10.1016/0006-291X(89)92183-9

Shi, X., Leonard, S., Liu, K., Zang, L., \& Gannett, P. (1998). Cr (III)-mediated hydroxyl radical generation via Haber-Weiss cycle. Journal of Inorganic. Retrieved from http:/www.sciencedirect.com/science/article/pii/S016201349710037X

Sies, H. (1993). Strategies of antioxidant defense. The FEBS Journal. Retrieved from http://onlinelibrary.wiley.com/doi/10.1111/j.1432-1033.1993.tb18025.x/full

Singh, R., De, S., \& Belkheir, A. (2013). Avena sativa (Oat), A Potential Neutraceutical and Therapeutic Agent: An Overview. Critical Reviews in Food Science and Nutrition, 53(2), 126144. http://doi.org/10.1080/10408398.2010.526725

Sowbhagya, H., Srinivas, P., \& Krishnamurthy, N. (2010). Effect of enzymes on extraction of volatiles from celery seeds. Food Chemistry. Retrieved from 
http:/www.sciencedirect.com/science/article/pii/S0308814609011911

Sowbhagya, H., Srinivas, P., \& Purnima, K. (2011). Enzyme-assisted extraction of volatiles from cumin (Cuminum cyminum L.) seeds. Food Chemistry. Retrieved from http://www.sciencedirect.com/science/article/pii/S0308814611002433

Srivastava, S., Singh, D., Patel, S., \& Singh, M. R. (2017). Role of enzymatic free radical scavengers in management of oxidative stress in autoimmune disorders. International Journal of Biological Macromolecules. http://oi.org/10.1016/j.ijbiomac.2017.03.100

Stearns, D., Courtney, K., \& Giangrande, P. (1994). Chromium (VI) reduction by ascorbate: role of reactive intermediates in DNA damage in vitro. Environmental Health. Retrieved from https:/www.ncbi.nlm.nih. gov/pmc/articles/PMC1567384/

Stern, A. H., Freeman, N. C. G., Pleban, P., Boesch, R. R., Wainman, T., Howell, T., ... Lioy, P. J. (1992). Residential exposure to chromium waste-urine biological monitoring in conjunction with environmental exposure monitoring. Environmental Research, 58(1-2), 147-162. http://oi.org/10.1016/S0013-9351(05)80211-7

Strychar, R., Webster, F., \& Wood, P. (2011). World oat production, trade, and usage. Oats: Chemistry and. Retrieved from https:/books. google.ca/books?hl=en\&lr=\&id=HhIvDAAAQBAJ\&oi=fnd\&pg=PA1\&dq=worl $\mathrm{d}+$ oat + production\&ots $=\mathrm{B} 4 \mathrm{~S} 7 \mathrm{v} 5 \mathrm{Xxwt} \&$ sig $=$ GOVBSM33 DyYhveZ81HxUUToBGbg

Suetsuna, K., Ukeda, H., \& Ochi, H. (2000). Isolation and characterization of free radical scavenging activities peptides derived from casein. The Journal of Nutritional Biochemistry. Retrieved from http:/www.sciencedirect.com/science/article/pii/S0955286399000832

Suzuki, K. T., Mandal, B. K., Katagiri, A., Sakuma, Y., Kawakami, A., Ogra, Y., ... Aimi, N. (2004). Dimethylthioarsenicals as arsenic metabolites and their chemical preparations. Chemical Research in Toxicology, 17(7), 914-921. http://doi.org/10.1021/tx049963s 
Tang, S., \& Hettiarachchy, N. (2003). Protein Extraction from Heat-stabilized Defatted Rice Bran: II. The Role of Amylase, Celluclast, and Viscozyme. Journal of Food. Retrieved from http:/onlinelibrary.wiley.com/doi/10.1111/j.1365-2621.2003.tb05696.x/full

TPA, D., JC, T., KK, B., Ketaki S, S., Saroj, G., \& Rodroclo, L. (2004). Free radicals and antioxidants in human health: current status and future prospects . PubMed Commons, 52, 794-804. Retrieved from https://www.researchgate.net/profile/Saroj_Ghaskadbi/publication/7831516_Free_Radicals_an d_Antioxidants_in_Human_Health_Current_Status_and_Future_Prospects/links/56ef793b08ae 4b8b5e756f2f.pdf

Tsopmo, A., Gao, Q., \& Baakdah, M. M. (2014). Reduction of hexavalent chromium by digested oat bran proteins. Food Chemistry, 153, 171-176. http://doi.org/10.1016/j. foodchem.2013.12.049

Turrens, J. F. (2003). Mitochondrial formation of reactive oxygen species. The Journal of Physiology, 552(2), 335-344. http://doi.org/10.1113/jphysiol.2003.049478

Udenigwe, C. C., \& Aluko, R. E. (2012). Food Protein-Derived Bioactive Peptides: Production, Processing, and Potential Health Benefits. Journal of Food Science, 77(1), R11-R24. http://doi.org/10.1111/j.1750-3841.2011.02455.x

Valko, M., Morris, H., \& Cronin, M. (2005). Metals, toxicity and oxidative stress. Current Medicinal Chemistry. Retrieved from http:/www.ingentaconnect.com/content/ben/cmc/2005/00000012/00000010/art00003

Valko, M., Rhodes, C. J., Moncol, J., Izakovic, M., \& Mazur, M. (2006a). Free radicals, metals and antioxidants in oxidative stress-induced cancer. Chemico-Biological Interactions, 160(1), 140. http $/ /$ doi.org/10.1016/j.cbi.2005.12.009

Valko, M., Rhodes, C. J., Moncol, J., Izakovic, M., \& Mazur, M. (2006b). Free radicals, metals and 
antioxidants in oxidative stress-induced cancer. Chemico-Biological Interactions, 160(1), 140. http $/ /$ doi.org/10.1016/j.cbi.2005.12.009

Vanvi, A., \& Tsopmo, A. (2016). Pepsin digested oat bran proteins: Separation, antioxidant activity, and identification of new peptides. Journal of Chemistry, 2016, 1-8. http://oi.org/10.1155/2016/8216378

Wang, C., Han, Y., Feng, B., \& Dong, Y. (2008). Study on extraction technology of oat peptide. Sci. Technol. Food Ind. Retrieved from http://en.cnki.com.cn/Article_en/CJFDTOTALSPKJ200806071.htm

Wang, S. Y., \& Jiao, H. (2000). Scavenging capacity of berry crops on superoxide radicals, hydrogen peroxide, hydroxyl radical's, and singlet oxygen. Journal of Agricultural and Food Chemistry, 48(11), 5677-5684. http://doi.org/10.1021/jf000766i

Wang, T. S., Shu, Y. F., Liu, Y. C., Jan, K. Y., \& Huang, H. (1997). Glutathione peroxidase and catalase modulate the genotoxicity of arsenite. Toxicology, 121(3), 229-237. http://oi.org/10.1016/S0300-483X(97)00071-1

Wang, Y.-C., Yu, R.-C., \& Chou, C.-C. (2006). Antioxidative activities of soymilk fermented with lactic acid bacteria and bifidobacteria. Food Microbiology, 23(2), 128-135. http://doi.org/10.1016/j.fm.2005.01.020

Watanabe, T., \& Hirano, S. (2013). Metabolism of arsenic and its toxicological relevance. Archives of Toxicology, 87(6), 969-979. http://doi.org/10.1007/s00204-012-0904-5

Wattanasiritham, L., Theerakulkait, C., \& Wickramasekara, S. (2016). Isolation and identification of antioxidant peptides from enzymatically hydrolyzed rice bran protein. Food Chemistry. Retrieved from http://www.sciencedirect.com/science/article/pii/S0308814615009498

Werfel, U., Langen, V., Eickhoff, I., \& Schoonbrood, J. (1998). Elevated DNA single-strand breakage frequencies in lymphocytes of welders exposed to chromium and nickel. Retrieved 
from https://academic.oup.com/carcin/article-abstract/19/3/413/2365393

Wiegand, H. J., Ottenw, H., \& Bolt, H. M. (1984). THE REDUCTION OF CHROMIUM (VI) TO CHROMIUM (III) BY GLUTATHIONE: AN INTRACELLULAR REDOX PATHWAY IN THE METABOLISM OF THE CARCINOGEN CHROMATE. Toxicology, 33, 341-348. Retrieved from http://ac.els-cdn.com/0300483X84900507/1-s2.0-0300483X84900507main.pdf?_tid=552bb0f2-8810-11e7-b15b00000aacb362\&acdnat=1503499118_d7aaec8e2661a3ecc27c0dc13eb3e60a

Wolfsperger, M., Hauser, G., \& Gößler, W. (1994). Heavy metals in human hair samples from Austria and Italy: influence of sex and smoking habits. Science of the Total. Retrieved from http://www.sciencedirect.com/science/article/pii/0048969794901902

Wood, P. J. (1994). Evaluation of oat bran as a soluble fibre source. Characterization of oat betaglucan and its effects on glycaemic response. Carbohydrate Polymers, 25(4), 331-336. http://doi.org/10.1016/0144-8617(94)90059-0

Xie, Z., Huang, J., Xu, X., \& Jin, Z. (2008). Antioxidant activity of peptides isolated from alfalfa leaf protein hydrolysate. Food Chemistry. Retrieved from http:/www.sciencedirect.com/science/article/pii/S0308814608004111

Yagi, K. (1987). Lipid peroxides and human diseases. Chemistry and Physics of Lipids. Retrieved from http $/ /$ www.sciencedirect.com/science/article/pii/0009308487900715

Yamanaka, K., Hoshino, M., Okamoto, M., Sawamura, R., Hasegawa, A., \& Okada, S. (1990). Induction of DNA damage by dimethylarsine, a metabolite of inorganic arsenics, is for the major part likely due to its peroxyl radical. Biochemical and Biophysical Research Communications, 168(1), 58-64. http//doi.org/10.1016/0006-291X(90)91674-H

Yamanaka, K., Mizoi, M., \& Kato, K. (2001). Oral administration of dimethylarsinic acid, a main metabolite of inorganic arsenic, in mice promotes skin tumorigenesis initiated by dimethylbenz 
(a) anthracene with. Biological and. Retrieved from

https:/www.jstage.jst.go.jp/article/bpb/24/5/24_5_510/_article/-char/ja/

Yeh, C.-C., Hou, M.-F., Tsai, S.-M., Lin, S.-K., Hsiao, J.-K., Huang, J.-C., ... Tsai, L.-Y. (2005). Superoxide anion radical, lipid peroxides and antioxidant status in the blood of patients with breast cancer. Clinica Chimica Acta; International Journal of Clinical Chemistry, 361(1-2), 104-11. http://doi.org/10.1016/j.cccn.2005.05.002

Young, I., \& Woodside, J. (2001). Antioxidants in health and disease. Journal of Clinical Pathology. Retrieved from http://jcp.bmj.com/content/54/3/176.short

Zayas, J. (1997). Solubility of proteins. Functionality of Proteins in Food. Retrieved from http://link.springer.com/chapter/10.1007/978-3-642-59116-7_2

Zhu, K., Zhou, H., \& Qian, H. (2006). Antioxidant and free radical-scavenging activities of wheat germ protein hydrolysates (WGPH) prepared with alcalase. Process Biochemistry. Retrieved from http://www.sciencedirect.com/science/article/pii/S1359511306000043

Zhu, K., Zhou, H., \& Qian, H. (2006). Proteins extracted from defatted wheat germ: nutritional and structural properties. Cereal Chemistry. Retrieved from http://aaccipublications.aaccnet.org/doi/abs/10.1094/CC-83-0069 